Portland State University

PDXScholar

\title{
A Study of the Success of School College Partnerships Created to Improve Minority and Disadvantaged Student Enrollment and Success in Postsecondary Education
}

Armando Reinaldo Laguardia

Portland State University

Follow this and additional works at: https://pdxscholar.library.pdx.edu/open_access_etds

Part of the Educational Administration and Supervision Commons Let us know how access to this document benefits you.

\section{Recommended Citation}

Laguardia, Armando Reinaldo, "A Study of the Success of School College Partnerships Created to Improve Minority and Disadvantaged Student Enrollment and Success in Postsecondary Education" (1995).

Dissertations and Theses. Paper 1309.

https://doi.org/10.15760/etd.1308

This Dissertation is brought to you for free and open access. It has been accepted for inclusion in Dissertations and Theses by an authorized administrator of PDXScholar. Please contact us if we can make this document more accessible: pdxscholar@pdx.edu. 
A STUDY OF THE SUCCESS OF SCHOOL/COLLEGE PARTNERSHIPS

CREATED TO IMPROVE MINORITY AND DISADVANTAGED

STUDENT ENROLLMENT AND SUCCESS IN

POSTSECONDARY EDUCATION

by

ARMANDO REINALDO LAGUARDIA

A dissertation submitted in partial fulfillment of the requirements for the degree of

\author{
DOCTOR OF EDUCATION \\ in \\ EDUCATIONAL LEADERSHIP: \\ ADMINISTRATION AND SUPERVISION
}

Portland State University

O1995 
UMI Number: 9542387

Copyright 1995 by Laguardia, Armando Reinaldo

All rights reserved.

UMI Microform 9542387

Copyright 1995, by UMI Company. All rights reserved.

This microform edition is protected against unauthorized copying under Title 17, United States Code.

\section{UMI}

300 North Zeeb Road Ann Arbor, MI 48103 
The abstract and dissertation of Armando Reinaldo Laguardia for the Doctor of Education in Educational Leadership: Administration and Supervision were presented May 3, 1995, and accepted by the dissertation committee and the doctoral program.

COMMITTEE APPROVALS:
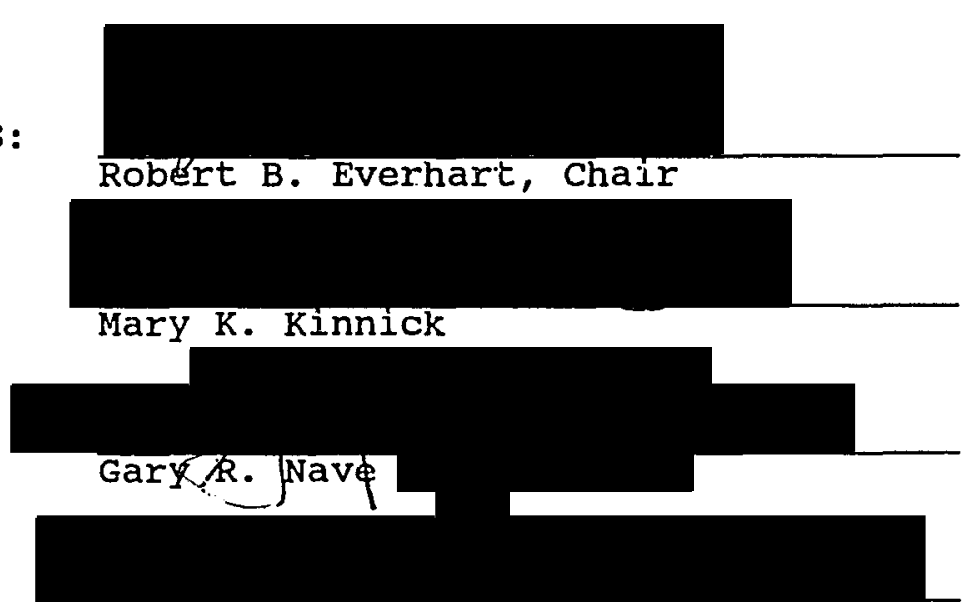

Jqan H. Strouse

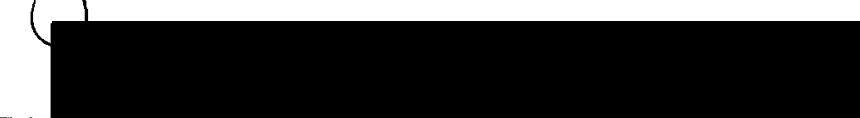

Darrell M. Millner

Representative of the office of Graduate studies

DOCTORAL PROGRAM APPROVAL:

Robert B. Everhart, Dean

School of Education

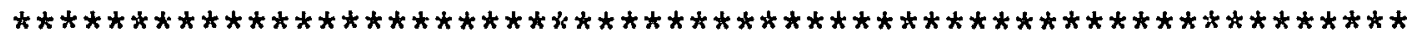

ACCEPTED FOR PORTLAND STATE UNIVERSITY BY THE LIBRARY

by
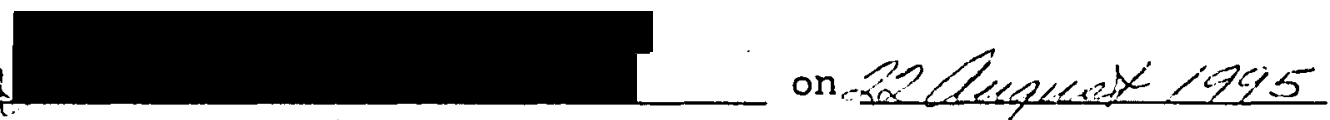
ABSTRACT

An abstract of the dissertation of Armando Reinaldo Laguardia for the Doctor of Education in Educational Leadership: Administration and Supervision presented May 3, 1995.

Title: A study of the success of school/College Partnerships Created to Improve Minority and Disadvantaged student Enrollment and Success in Postsecondary Education

This study focused on "comprehensive" partnerships between $\mathrm{K}-12$ schools and postsecondary institutions created to improve the pre-college academic preparation, college enrollment and postsecondary success of minority and disadvantaged students. The study identified such partnerships in existence in the United States for more than five years, surveyed the partnerships to describe their characteristics, and select two of the most successful to analyze their success characteristics.

sixteen such partnerships were identified and surveyed with a 12-item questionnaire designed to inquire about their: (a) structural characteristics, (b) funding, (c) success in achieving their goals and objectives, and (d) 
collection of data to measure success. Three key informants from each partnership were surveyed. Forty of 48 surveys were returned, for a return rate of $82 \%$. Responses were tabulated to ascertain the degree to which these partnerships had been successful in achieving their goals and identify the areas in which they experienced success. Two of the most successful partnerships were selected for case studies and visited to collect information about the factors that affected their success and to interview five key participants who represented schools and postsecondary institutions in each of the partnerships. An interview protocol was used to probe the degree to which the characteristics of partnerships success identified in the literature (Van de Water, 1989) were present and effected the case study partnerships. Analysis of the surveys, partnership materials, and the interviews provided a comprehensive portrait of each of the study partnerships. Results of the surveys indicate that a majority of these partnerships; consider themselves at least somewhat successful in achieving their goals, and have improved high school preparation and college enrollments. They are, however, less informed about their success in increasing college retention and graduation.

The case studies and interviews revealed that the partnerships valued the success characteristics identified in the literature. The most salient characteristics 
required for success were the existence of leadership capable of negotiating change within several institutions with different organizational cultures, and the need to recognize that partnerships are unique organizations with some of the same peculiarities, structures and needs as other organizations. 


\section{DEDICATION}

As an educator I have always recognized the important contributions that parents make to the success of their children. This study is dedicated my father Pedro Laguardia and to the memory of my mother carmen santana. They always instilled in me the confidence to pursuit my interests, the courage to persevere in the face of adversity, the believe that I had the ability to do anything I wanted to and the discipline to study and learn. They deserve more credit for the completion of this study than anyone else.

This study is also dedicated to my children carlos, Carmen and Kenya my grandchildren symone and Carlos Jr. and to the policy makers, teachers, administrators, faculty and community members who have participated and will participate in the creation of collaboratives and partnerships to improve the preparation of minority and disadvantaged students. 


\section{ACKNOWLEDGEMENTS}

I would like to express my gratitude to all those who made this study possible with their generous contributions of time, insight, expertise and encouragement including the many partnership participants who responded to the surveys and int:erviews that were an integral part of this study.

I am also grateful to many at Portland state University, my Dissertation Committee Members: Dr. Mary Kinnick, Dr. Darrell Millner, Dr. Gary Nave, and Dr. Joan Strouse. MY Dissertation Committee Chair, Dr. Robert Everhart deserves special recognition for his constant support, motivation and untiring review and advice in the formulation and completion of this study.

Dr. John Heflin encouraged me to pursuit doctoral studies and served as my Program Advisor. Dr. Dalton Miller-Jones was instrumental with his encouragement and made it possible for me to concentrate on this study. I will always be grateful for their friendship and collegiality.

I am eternally grateful for the support, encouragement, and valuable editorial assistance I received from my partner Karen Bates and for the constant encouragement of my sister Ada Laguardia and brother-in-law steve Riddle. They all helped me keep body and soul together during this arduous process. 
ACKNOWLEDGEMENTS. . . . . . . . . . . . . . . . . ii

IIST OF TABLES. . . . . . . . . . . . . . . . . vii

LIST OF FIGURES . . . . . . . . . . . . . . . . ix

\section{CHAPTER}

I INTRODUCTION . . . . . . . . . . . . . . 1

Rationale for this study . . . . . . . 4

Postsecondary Adaptations. . . . . . 10

Research Problem . . . . . . . . 12

Sample for the study

II REVIEW OF RELEVANT LITERATURE. • • • • • • • . 15

The Early Phase of Collaboration . . . . 17

Higher Education Consortia

Collaboration Between Schools and Colleges

The Transitional Period. . . . . . . . 23

The Recent Surge in School/College

Partnerships... . . . . . . . 26

Factors Contributing to the surge in School/College Partnerships

The Influence of the Reform Agenda

Priorities of Recent Partnerships

The Literature on Organizational Factors

Affecting Partnerships . . . . . . . 43 
The success of Collaboratives. . . . . 45

Literature on the Characteristics of Successful Collaboratives

Summary. . . . . . . . . . . . . 49

III METHODOLOGY. . . . . . . . . . . . 53

Research Problem and Questions . . . . 53

Sample . . . . . . . . . . . 54

Characteristics of the Partnerships to be studied

Partnerships Identified

Partnerships studied

Research Methodology , . . . . . . . 67

Survey

Case Studies

Data Analysis

Interviewees

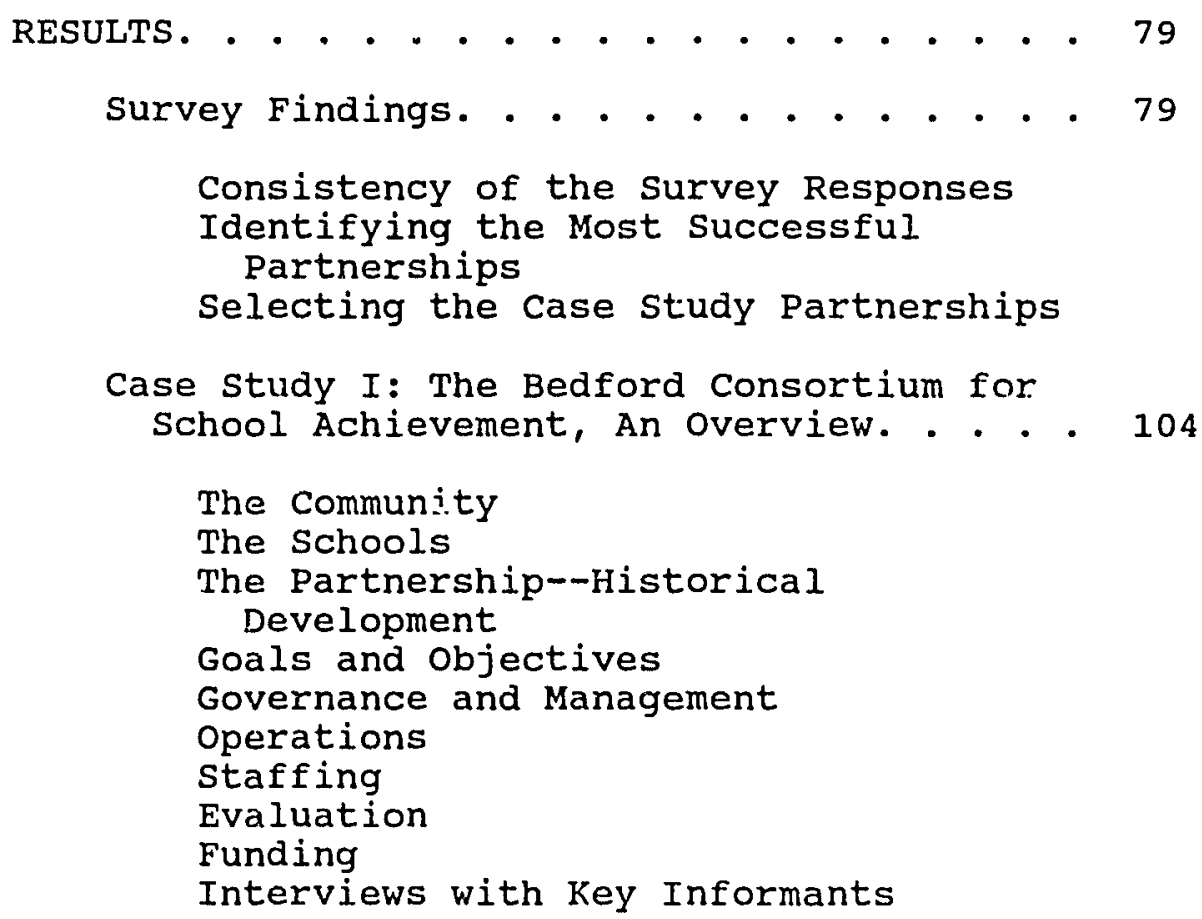


Case study II: The Toledo school college

Compact, An Overview . . . . . . . . 142

The Community

The Schools

The Partnership--Historical

Development

Goals and objectives

Development and operations

The Administrative Council

standing committees

staffing

Evaluation

Funding

Outcomes

Interviews with Key Informants

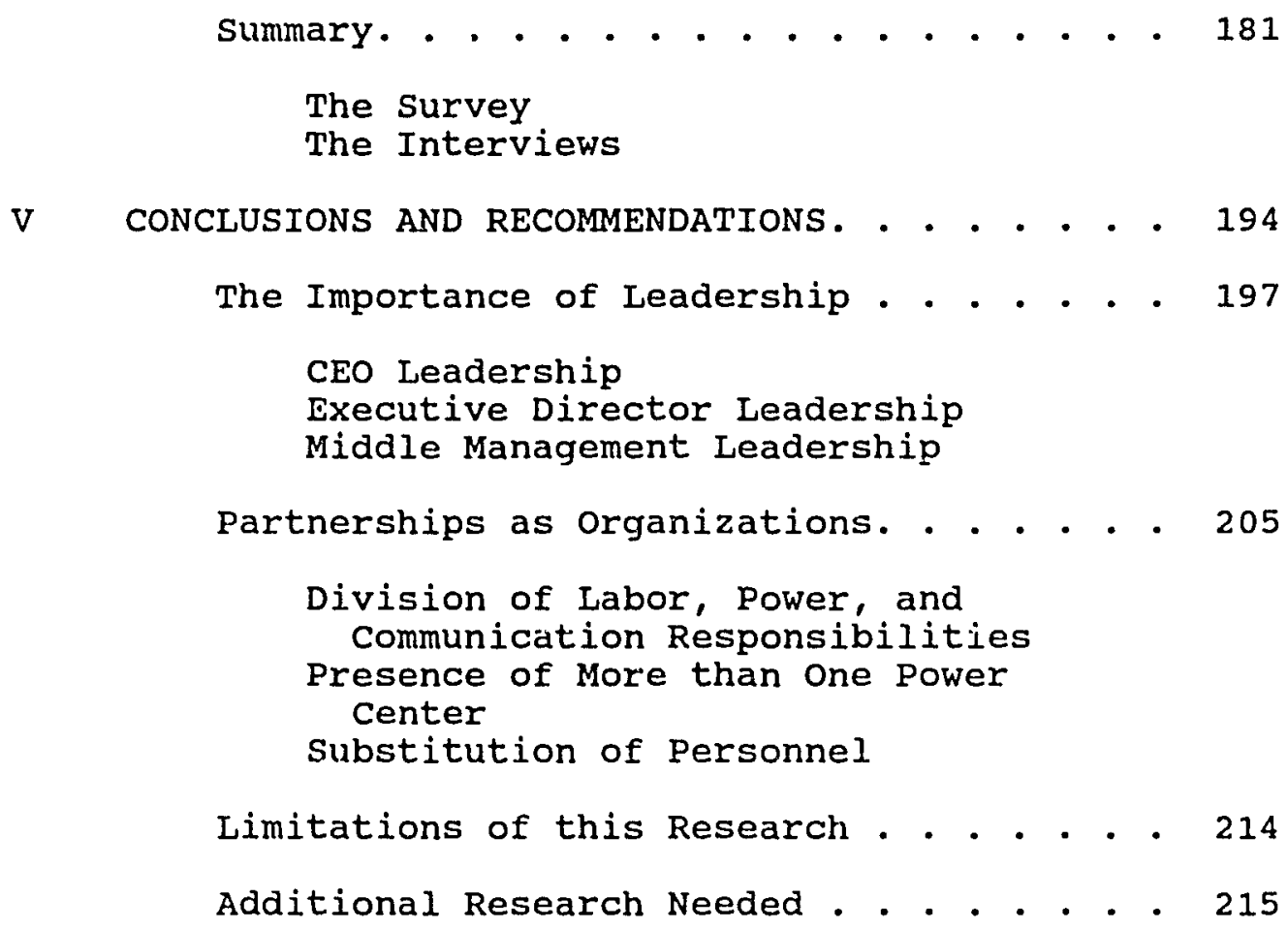

REFERENCES. . . . . . . . . . . . . . 220

APPENDICES

A IJST OF PARTNERSHIPS . . . . . . . . . . . 228
B DATA SEARCH REQUEST. . . . . . . . . . . . 231
C SURVEY QUESTIONNAIRE . . . . . . . . . . . 236 
D CORRESPONDENCE . . . . . . . . . . . . 241

E TNTERVIEW PROTOCOL . . . . . . . . . . 243 


\section{LIST OF TABLES}

1. Partnerships in this study . . . . . . . 64

2. Partnerships that Terminated Before the Study Began. . . . . . . . . . . . . 66

3. Number of Partnership Responses to Survey. . . 72

4. Interview Protocol . . . . . . . . . . 74

5. Timeline for the study . . . . . . . . 78

6. Structural Characteristics of the Partnerships . . . . . . . . . . . 81

7. Levels of the Partnerships' Annual Budgets . . 82

8. Extent to Which Partnerships Define and Monitor their Goals. . . . . . . . . 83

9. Factors that Influenced the Initial Formation of the Partnerships. . . . . . 84

10. Extent to which Some of the Partnership Objectives Are Met . . . . . . . . . . 86

11. Data collected by the Partnerships to Measure Success. . . . . . . . . 88

12. Consistency of Survey Responses. . . . . . . 91

13. Partnership Groups . . . . . . . . . . 93

14. Structural Characteristics of the Partnerships by Groups . . . . . . . . . 94

15. Total Budget of the Partnerships by Group. . . 94

16. Objectives Met to a Substantial Degree by the Partnerships... . . . . . . . . 96

17. Achievement of Objective Improve High School Preparation by Group I Partnerships . . . . . . . . . . . . . 99 
18. Achievement of objective Increase Minority Higher Education Enrollment by Group I Partnerships . . . . . . . . . . . . . 99

19. Achievement of Objective Improve Minority student college Retention by Group I Partnerships.............. 100

20. Achievement of objective stimulate Research by Group I Partnerships. . . . . . . . . 100

21. Achievement of Objective Promote Relationship Between the College/School Staffs by Group I Partnerships . . . . . . . . . . . . 101

22. Achievement of objective Improve Image and Community Relations of the colleges by Group I Partnerships . . . . . . . . . 101

23. Achievement of Objective Institutional Change and Reform by Group I Partnerships. . 102

24. Achievement of Objective A Base for Seeking External Funds by Group I Partnerships . . . 102

25. Objectives Met to a Substantial Degree by the Group I Partnerships. . . . . . . . 103

26. Results of the 1980 Evaluation of the Consortium objectives. . . . . . . . . 118

27. The Map of Compact: Associated Initiatives for Local Systemic Reform, 1993-1995 . . . 157 
LIST OF FIGURES

FIGURE

PAGE

1. Toledo School College compact

Organizational Chart . . . . . . . . . 151 


\section{CHAPTER I}

\section{INTRODUCTION}

Inter-institutional cooperation between colleges and schools in the United States is not altogether new. Higher education institutions have played a major role in nurturing curriculum development and setting standards for high school education. Henry Tappan, president of the University of Michigan (1852-1863), worked with the Michigan public schools to establish mutually agreeable academic standards, thus setting precedent for future relationships between higher education and public high schools. In these relationships higher education has traditionally set the standards and public high schools have reacted to them.

Boyer (1983a) noted that collaborative efforts between K-12 schools and postsecondary education were the exception rather than the rule:

Today with all the talk about educational exceilence, schools and colleges still live in separate worlds. Presidents and Deans rarely talk to principals and district superintendents. College faculty do not meet with their counterparts in public schools, and curriculum reforms at every level are planned in isolation. It's such a simple point--the need for close collaboration--and yet it is a priority that has been consistently ignored. Universities pretend they can have quality without working with the schools, which are, in fact, the foundation of everything universities do. (p. 11) 
In the last decace, however, school/college collaboratives have been growing at an accelerated pace. Wilbur and Lambert (1991) surveyed colleges and universities nationwide in order to learn about the nature and extent of their partnerships with schools. The responses of 1,286 colleges and universities, when compared with a similar survey conducted in 1987 (Wilbur, Lambert, \& Young, 1988), revealed a marked increase in the number and scope of partnerships.

Partnerships are found in every state in both public and private institutions. of the colleges and universities responding to the Wilbur and Lambert (1991) survey, 882 were public and 404 were private. These school/college partnerships were grouped by wilbur and Lambert into the following categories: (a) Programs and Services for Students; (b) Programs and Services for Educators; (c) Coordination, Development, and Assessment of Curriculum and Instruction; and (d) Programs to Mobilize, Direct, and Promote Sharing of Educational Resources. Partnerships that focus on the provision of programs and services to students have grown most rapidly and constitute the largest percentage of school/college collaboratives. (Forty-three percent of the partnerships identj.fied by Wilbur and Lambert [1991] in their guide to partnerships were initiated for the purpose of creating programs and services for students.) These partnerships are 
frequently created to increase college enrollments and influence the academic preparation of secondary students. As I will discuss, students from ethnic minority groups are projected to compose large portions of the traditional college attending age cohorts in the future, but their preparation for college is inferior by most standards. Increasing the college enrollment rates of minority students is a societal goal to which the public and private sectors have invested considerable time and resources. As a result, many of these new partnerships strive to increase the number of ethnic/racial minority students who are prepared for, enroll in, and succeed in postsecondary education. These school/college partnerships, designed to improve minority and disadvantaged student enrollment and success in postsecondary education, are the focus of this study. The term "minority" is used in this study as a synonym for individuals who identify themselves as members of four ethnic or racial groups in the United States: African Americans, Asian and Pacific Islanders, Hispanics, Native Americans and Alaskan Natives. These groups are deemed to have been the object of historical discriminatory treatment in such proportions that it has put them at a societal disadvantage and deprived them of equal opportunities. They have been classified as "protected classes" by federal government agencies for the purpose of attempting to facilitate their integration into the mainstream of American 
society and improve their employment and educational opportunities. These groupings and terminology are consistent with those used by the United states Equal Employment Opportunity Commission, the office for civil Rights of the U.S. Department of Education and the office of Federal Contract compliance.

The term disadvantaged for the purpose of this study is used to designate students who are from low income families (economically disadvantaged) or performing at lower levels than their peers in school (academically disadvantaged). Low income and inadequate school performance have been identified as significant indicators of possible school failure and subsequent social dislocation. Many public and private educational programs target these students for special assistance. Disproportionately high numbers of minority students are also low income and academically disadvantaged. Most of the partnerships identified for this study serve both minority and disadvantaged students.

\section{Rationale for this study}

Mickelson, Kritek, Hedlund, and Kaufmann (1988), in their study on urban school/university collaborations, found that the lack of minority enrollments in college was one of the problems most frequently cited as the reason for the formation of school/university partnerships. At least $50 \%$ of the superintendents and college presidents surveyed by 
Mickelson et al. indicated that the increase of minority students in postsecondary institutions is a primaxy or secondary objective of their partnersinips.

A major contribution to this widespread concern is the shift in the composition of the present and future population of students who are projected to attend postsecondary institutions. The reality is that an increasing proportion of our population is composed of people of color. In the 15 years between 1985 and the year 2000 , the U.S. population is projected to increase by $12.3 \%$ (Levine, 1989, p. 18). Nearly $60 \%$ of this growth will occur among ethnic minority populations (African American, Asian American, Hispanic and Native American). The overall growth rate for this period includes a projected $23.0 \%$ for Blacks, 45.0\% for yispanics, and $48.8 \%$ for other minority groups, compared to a $6.5 \%$ increase in the White population.

Some states have experienced significantly higher influxes of immigrants. Between 1982 and 1986,798 to $86 \%$ of all foreign immigrants settled in 15 states, and $61 \%$ of these immigrants settled in just four states--California, Florida, New York, and Texas (Levine, 1989, p. 19) . Eightyseven percent of all immigrants in 1986 were from Asia, Africa, Mexico, the Caribbean, and central and South America, and many of these are considered members of minority groups. By the year 1998 (in the states of California, Florida, New York, and Texas), a substantial 
share of the projected reduction in the number of 18-year-olds due to declining birthrates will be offset by minority group immigrants. overall then, in Florida the proportion of minorities will rise from 298 to almost 418 , and in Illinois the minority share will climb from almost $24 \%$ to $32 \%$. Comparable figures for Texas and California show increases from $38 \%$ to almost 498 and from $32 \%$ to nearly 42\%, respectively. If in-migration continues at anywhere near the current rates until the end of the century, the numbers will add dramatically to the share of minorities in those states that are the major recipients of immigrants.

These expanding minority populations tend to be younger than the majority population, reflecting a larger proportion of children and adults of childbearing age. Ultimately these increases are bound to be reflected in the minority percentage of the college age population. This trend, moreover, is compounded by the decline in the birthrate of the U.S. born White population.

Birthrate statistics alone no longer form the basis for an accurate projection of college enrollments. In-migration, both legal and illegal, is expected to continue influencing the college age cohorts disproportionately across the country. Between 1979 and 1998, the white college-age population (18- to 21-year-olds) is projected to decline by 218 (Levine, 1989, p. 163). The number of African-Americans in this age group within the 
general population will decrease by $11 \%$, while the number of 18- to 21-year-olds of Hispanic heritage will increase by 10\%. The number of Asians will rise by a substantially higher proportion.

One of the dilemmas and potential challenges faced by the educational community is that, although the college-age population of Hispanics is on the rise, and the Black college-age population is expected to decrease only slightly, the rates of college attendance by both Blacks and Hispanics have actually declined since 1976. Meanwhile the college attendance rate of whites is up slightly despite their declining numbers within the college-age group. The rate for Asians is increasing sharply along with their growing numbers; however, the high rate of college attendance for this group reflects its overall higher economic position in relation to other minorities. Asians may see a shift downward in college enrollment since the newer and rapidly growing immigrant groups, such as the Vietnamese, have poverty rates as high as those for Puerto Ricans and Mexican Americans.

The most rapidly growing groups in our population also have lower high school graduation rates. For example, the high school completion rate of minority students is significantly inferior to that of their white counterparts, who in 1985 had a national high school graduation rate of 77\%. By contrast African Americans of the same age cohort 
had a graduation rate of $63 \%$, and Hispanics had a $50 \%$ high school graduation rate (Levine, 1989, p. 21). These lower levels of high school graduation rates underscore an apparent inability of the educational system to educate minority students successfully.

These demographic trends are of special concern for policy makers because a high percentage of the population growth will be among groups experiencing low educational achievement who are underprepared for postsecondary education. The largest of the nonwhite groups (Hispanics and Blacks) have the highest rates of poverty and the lowest rates of educational attainment, and their presence at the postsecondary educational level has been steadily declining for the past two decades.

Given the growing impact of postsecondary education on the ability of individuals to secure higher paying professional employment and consequently higher social status, one projected scenario for our future is that of an overwhelmingly white educated elite who control the arenas of technology and finance, while the less-educated minority groups are found concentrated in the rapidly-evolving but relatively poorly paid service sector. clearly, then, the task of postsecondary education to enhance the educational and thus life opportunities of the minority population is more critical than ever. 
Since the greatest population growth is occurring among minority groups-mand minorities compose an increasing share of the college-age population--the higher education community is now taking seriously the need to make school systems and institutions of higher education more responsive to the needs of minority students. It is clear that colleges and universities will be forced to recruit and serve a population with larger numbers of minorities established in this country as well as substantially increased numbers of relatively new immigrants.

Yet given the history of inadequate pre-collegiate preparation for minority students, it is questionable whether future high school graduates will enter college with the requisite aptitudes as well as attitudes necessary for success. Thus, the higher education community is concerned not only with the level of academic preparation of high school students who will enter colleges and universities but also with the motivational characteristics of the students who arrive at their doors.

In summary, the college-age population will

increasingly be comprised of people of color. The largest of these groups, Hispanics and Blacks, have the highest rates of poverty and the lowest rates of educational attainment, as attested by their higher dropout rates and their declining attendance in postsecondary education. In order to ensure that future youth will, in fact, transcend 
the aptitudinal and attitudinal characteristics of today's minorities, substantial cooperation between the higher education and the $\mathrm{K}-.12$ systems will be needed in order to increase the academic preparation of minority students. Those challenges add particular significance to this study of school/college partnerships.

\section{Postsecondary Adaptations}

The apparent influence of academic preparation and family income on the ability of minority students to attend college has prompted concern and actions on the part of private and public systems of higher education. Many colleges and universities are attempting to identify solutions to two problems: (a) under-preparation in high school and (b) financial assistance and academic support for minority and disadvantaged students in college. The actions of higher education have resulted in an explosion of cooperative initiatives and collaborations involving $\mathrm{K}-12$ schools, two-year colleges, and four-year colleges.

Those who follow the school/college collaboration phenomena recognize the growth and significance of the actions currently being taken. Stoel, Tognery, and Brown (1992) of the office of school/College collaboration of the American Association of Higher Education acknowledged such efforts in their compendium on school/college partnerships.

Today practically every college and university in the nation hosts at least one partnership program, 
and many campuses have multiple partnerships. Many, if not most, help students to beat the odds. students who would not otherwise go to college are taking college preparatory courses, graduating from high school, and going on to college because of special efforts of these programs. (p. 2)

Yet, the wholesale creation of partnerships to increase the number of minority and disadvantaged urban students who enroll in postsecondary institutions is a relatively new development. Because partnerships are still in their infancy, there has not been sufficient opportunity to study their characteristics or record of success. Consequently, there is very little research on the factors that make school/college partnerships successful. Even less research is available on the success of those partnerships created primarily for minority students.

The lack of research and data on these collaboratives has prompted a call for the analysis of outcomes regarding school/college partnerships. Greenberg (1991) prepared a report on school/college partnerships for the Educational Resources Information Center (ERIC) and the Association for the study of Higher Education. Greenberg argued that more data are needed on what happens to program participants before, during, and after their involvement with a partnership. He was concerned that "model" school/college partnerships were so designated because of reputational reports or because they are sponsored and supported by prominent organizations. 
There is a high probability that school/college partnerships focusing on the improvement of educational opportunities and postsecondary success for minority students will remain a significant endeavor for educational institutions. Therefore, it is important to explore whether these partnerships are successful, identify the factors that contribute to their success, and assess the degree to which those factors have affected current partnerships. This study makes a significant contribution to the needed exploration of the success of such partnerships.

\section{Research Problem}

The objectives of this study are the following: (a) to identify selected comprehensive partnerships that focus on the increased participation and success of minority and disadvantaged students in secondary and postsecondary education; (b) to identify those partnerships that are the most successful; and (c) to enumerate the factors affecting the success of these partnexships, with special attention to criteria noted in the literature on partnerships. Given these objectives, the research questions to be addressed include:

1. To what degree have school/college partnerships that serve minority and disadvantaged students defined and achieved their desired outcomes? 
2. To what extent have those partnerships incorporated previously identified "success characteristics," and have those characteristics contributed to their success?

3. How do these factors affect the opportunities for the success of the partnerships?

\section{Sample for the study}

The partnerships selected for this study are "comprehensive" partnerships, or those that involve several institutional or "segmental" levels of educational organizations. They typically include a school district or. districts, a community or junior college, at least one fouryear college or university, and community and business organizations. These partnerships represent a regional commitment and strategy to enact institutional policies and practices and a recognition that community-wide support is needed for the success of these enterprises. Comprehensive partnerships are created to produce large-scale change in the numbers of minority and disadvantaged students who enroll and succeed in college. These partnerships appear to require a different level of collaboration, support, and governance than the more limited cooperative arrangements between two entities (i.e., one college/one school). only comprehensive partnerships that focus on minority and disadvantaged students and have endured for at least five years were studied. Partnerships that had survived at least five years were considered successful in surpassing 
the early formative period of partnership formation. The study surveyed all such identifiable partnerships in the U.S. and conducted in-depth case studies on two of them. The following chapter reviews the relevant literature on the formation of collaboration in education with a focus on; the growth of the partnerships between schools and college, the influence of several forces on the growth of partnerships, and the literature on the success characteristics of partnerships. 


\section{CHAPTER II}

\section{REVIEW OF RELEVANT IITERATURE}

This chapter presents a review of relevant literature concerning the school/college collaboration phenomena. As the call for school/college collaboration has grown, so too has the need to articulate the nature of the collaborative effort. Hord (1986) defined collaboration in terms of "parties involved in shared responsibility and authority for basic policy decisions" (p. 22). Ladd (1969) asserted that each constituency in a collaborative relationship must negotiate its role within the context of its particular contribution and funding. Collaboration, however, does not necessarily signal mere cooperation or a matter of good will; it is an agreed upon distribution of status, power, and authority. In short, collaboration is a "partnership" which incorporates two-way communication, mutual rights and responsibilities, with an opportunity to accomplish jointly those goals the institutions could not achieve separately. The terms "collaboration" and "partnership" are therefore used interchangeably in the literature and in this review. one of the accepted definitions of partnerships is offered by Goodlad (1984). According to his definition, 
partnerships must have at least the following three essential characteristics:

1. A degree of dissimilar functions, responsibilities and resources among the partners;

2. The mutual satisfaction of self-interest;

3. A measure of selflessness on the part of each party sufficient to assure this satisfaction of self-interest by all involved.

These essential factors are especially true in school/college collaborative efforts where local districts, school boards, community groups, teachers, and administrators all have conflicting needs and vested interests. Negotiation of these varying interests and needs is necessary for the collaborative effort or partnership to be effective.

The literature examined in this review was drawn from a variety of sources, including reports from commissions and professional associations, journal articles, books, doctoral theses, project reports, and other information obtained in an Educational Resources Information Center (ERIC) search. The literature shows three phases in the development of school/college partnerships: (a) the early phase of collaboration, which lasted from World War II through the 1950s; (b) the transitional period, occurring in the 1960s and 1970s; and (c) the recent surge of collaboratives over 
the last 20 years and their focus on minority and disadvantaged student populations.

After reviewing the literature on each of these developmental stages, this chapter reviews the literature concerning the characteristics of success within collaboratives and makes an argument for the need to study the elements that purport to contribute to the collaboratives' success.

The Early Phase of Collaboration

A discussion of the early phase of educational collaboration follows. It is organized in two sections: early experiences of higher education consortia and collaboration between schools and colleges.

\section{Higher Education Consortia}

Before World War II, the uses of inter-institutional collaboration in education consisted of "consortia" in higher education. Higher education consortia were limited in numbers and were formed primarily to share institutional resources for the purpose of enhancing the ability of the institutions to serve their traditional and present populations. Generally, higher education consortia have been formed to: (a) provide more services to students with minimal additional costs through the collaborative offering of courses; (b) eliminate the duplication of academic programs; (c) share high cost resources such as specialized 
faculty members, computers, and television systems; (d) create programs and services, especially those that attract grant funds; and (e) maximize the advantages of size and diversity with special reference to fund raising, mass purchasing, and political lobbying (Scott, 1977, p. 1).

Neal (1988) pointed to the claremont Colleges, founded in 1925, and the Atlanta University Center, which originated four years later, as the first examples of such consortia. The growth of these consortia was slow following World war II and did not intensify until the 1960s, when a rapid increase in private and public support and funding for the higher educational consortia led to a parallel rise in their numbers and a change in their focus.

\section{Collaboration Between Schools} and Colleges

As noted, collaboration between colleges and secondary schools in American education has been fairly recent. Gross (1988, p. 1) asserted that before World War II only teachertraining institutions concerned themselves with the continuum of education. However, the 1957 launching of "Sputnik" (the first satellite) and the deepening cold war between the United States and the Soviet Union are forces frequently identified as influential in moving collaboration to a new level. These forces heightened the urgency for military and technological development, resulting in advancement of academic pursuits in science and technology, 
as well as in other areas (Greenberg, 1991; Gross, 1988; Maeroff, 1983).

Yet the early years of the postwar era was marked by an imbalance in the collaborative relationships between schools and colleges. Higher education dominated initial interactions with the public schools with some observers charging that, despite the lip service given in various conferences, studies and committees, "school representatives were always placed in a minority role in the relationship" (Elicker, 1956, p. 424). This imbalance was somewhat understandable, for until the 1950 s colleges and universities had few concerns about attracting candidates. Postsecondary education was viewed as the domain of the privileged and the well-prepared, and the colleges largely set the curriculum for high schonls. The sahool/colloge relationship of this period focused on the transition of "superior students" from secondary schools to colleges and universities.

Discussions by school and college professionals during the late 1940 s and 1950 s began to reflect two general concerns: (a) lack of communication between the school personnel and the college admission personnel (Traxler \& Townsend, 1953) and (b) lack of continuity between the last two years of high school and the first two years of college (Bacon, 1951; Blackmer, 1952). For colleges and universities then, essential concerns centered on the need 
to improve the relationship between schools and colleges for the primary purpose of controlling the flow of students from one to the other (Smith, 1988).

Pressures for the improvement of the linkages between high school and college lead to early examination of some relevant issues. In 1951 , representatives from three independent schools (Phillips Andover Academy, The Phillips Exeter Academy, and the Lawrenceville School) met with representatives of three universities (Harvard, Princeton, and Yale) to examine the lack of continuity between the last two years of high school and the first two years of college (Smith, 1988). Their study resulted in a report supported by the Fund for the Advancement of Education (FAE) entitled, "General Education in School and College." This report identified two woaknoscos in the connectian hatwesn sahool and college: (a) the inefficiencies associated with curriculum duplication and (b) the failure of teachers to actively engage students.

The FAE (1953) and the Ford Foundation issued a second report, "Bridging the Gap Between school and College," which described the relationship between schools and colleges as a system of poorly connected parts held together through a series of chronological "lock steps." The Fund argued that there existed "poor articulation between high school and college, which imposed wasteful repetitions and discontinuities on the educational process" (p. 12). In 
this second report the Fund presented the problems as differentially viewed by the high schools and by the colleges. The high schools were confronted with the problem of providing the best possible education with limited resources to a population that was not only expanding, but also had increasingly diverse career objectives. For the colleges, the dilemmal was to devise an academic program to accommodate increased number of students who varied widely in both academic preparation and attitude. This report raised the issue of the appropriate division of labor between schools and colleges in providing general education. To begin to address these problems, the Fund initiated four projects, in thel1950s, in an attempt to analyze different approaches to bridge the gap between schools and colleges (FAE. 1953). Two nrojects--the Adams/Morgan Project and the Portland/Reed Project--were among a few early experiences that foreshadowed some of the pitfalls that can besiege collaborations. One of those projects, entitled "A Public School Program for students of Exceptional Endowment," involved a cooperative effort between the Portland (Oregon) Public School system and Reed College. This project was initiated as part of a response to a study of juvenile delinquency which revealed that a surprisingly large portion of youth in trouble were above average in intellectual competence. One of the features of the project was its management by a "Liaison Committee" of 
five members--two from the Portland Public School system, two from Reed College, and a director who was also a member of the school superintendent's staff. The project was guided by its goal to motivate and challenge students identified as talented but troubled. It used cooperative approaches such as experimenting with teaching methods that focused on groups and individuals, coordination of teaching curriculum with other programs and community resources, and coordination of curricula between local high schools and colleges. This project helped set the stage for other collaboratives that would bring schools and colleges together in subsequent joint ventures.

Another project of the FAE (1953), the Adams/Morgan Project, involved the District of Columbia public school system, Antioch College, and the Adams/Morgan Community Council. The Adams/Morgan Project fostered a rather complicated set of relationships within a school/college cooperative by operating a community school with a variety of curriculum strategies and involvement in teacher and paraprofessional training. Ultimately, the project was plagued by "ill-defined allocation of responsibility and power among the participants" (Lauter, 1968, p. 235). The ambiguity of roles and the lack of a management strategy gave rise to irreparable misunderstandings and mistrust, and the project ultimately collapsed. 
These two projects were indicative of some of the serious obstacles experienced by early educational partnerships between high schools and colleges. These obstacles were due in part to the American educational system itself, seen by some as built upon a "San Andrea's" fault with the schools and colleges on opposite sides of the fault line (Frost, 1972). Stanfield (1981) described the school/university relationships as a "gulf, oceans wide and decades long" (p. 45), while Greenberg (1982, p. 66) spoke of an "abyss" between schools and postsecondary institutions. This condition was to change in the 1960s.

The Transitional Period

During the 1960s, the relationship between schools and colleges expanded into attempts at cooperative arrangements, marked by philosophical examinations and the recognition of barriers to collaboration. As the relationship between secondary schools and colleges came under increased scrutiny, theoreticai issues on the nature of learning emerged and influenced these discussions.

Bruner's (1960) contribution was one of these early influences. He emphasized that "any subject can be taught effectively in some intellectually honest form to any child at any stage of development" (p. 33). Bruner's hypothesis suggested that:

Through a carefully planned spiral curriculun, basic knowledge in a given subject can be 
presented and elaborated upon at successively more advanced grade levels. Moreover, it is far better to teach the inherent structure of basic subject areas instead of isolated facts and formulas that cannot be tied to a general pattern. (p. 21)

such a developmental approach challenged earlier assumptions that had focused on fixed ability as the determinant of student learning. Developmentalism also implied that learners can be reached at any time in this continuum and placed the onus on educators to look more closely at how schooling was organized in order to identify and serve student needs. When embraced and applied, a developmental approach suggests a more cooperative relationship between professionals in the education continuum, including school teachers and college professors, as well as more extensive cooperation between schools and colleges, The gradual acceptance of Bruner's hypothesis promoted the formation of communication networks regarding curriculum matters spanning from elementary schools to colleges.

Menacker (1975) argued that the educational system should be viewed as the sum of "administrative units" working in concert to facilitate rather than impede or interrupt the process of formal education. He was concerned that the differences between high school and college teachers--particularly the differences in teaching styles and their relationships to students--impeded student progress during the academic transition from one culture to 
the other. He advocated "direct teacher to teacher contacts to improve articulation between the two cultures" (Menacker, 1969, p. 220). At the same time, educators in both cultures recognized that the complexities of cooperative relationships required more attention than they had historically been given. Hochman and his colleagues (cited in Bacon, 1951) even urged that the College Board serve as a vehicle for a more constructive connection between the schools and colleges.

others believed that improving articulation simply by improving communication and understanding was not enough. Ladd (1969, p. 4) suggested that because the organizational cultures of high schools and colleges were different, new procedures to assist schools and colleges to work together had to be developed. Ladd was perhaps the first to identify the sources of tension working against joint ventures between schools and colleges:

1. Those endemic in inter-organizational collaboration (i.e., developing new arrangements and learning new habits);

2. Those arising from the differences between the goals of the schools and the goals of colleges;

3. Those deriving from non-essential differences between the two (i.e., policy making, daily activities, etc.).

The identification of these sources of tension provided a departure point for the development of new strategies to 
help overcome the characteristics that hinder school/college cooperation.

\section{The Recent Surge in School/College Partnerships}

In the past 20 years, larger numbers of colleges and universities in the U.S. have entered into partnerships with schools. Perhaps the most reliable measure of the growth and development of partnerships has been provided by the two national surveys on partnerships conducted by wilbur and Lambert (1988, 1991). These surveys were conducted to document the efforts undertaken by secondary schools and postsecondary institutions to answer some of the questions raised by the challenge to prepare minority and disadvantaged youth for higher education.

Wilbur, Lambert, and Young's (1988) first survey elicited approximately 1,000 responses; the second survey (Wilbur \& Lambert, 1991), conducted three years later, drew responses from 1,286 institutions, representing an increase of approximately $30 \%$. The second survey found that when respondents were asked to identify the year of the formation of their partnership, 114 indicated 1985, while 282 identified 1989 as the year of their formation. These responses point to a large increase in the number of partnerships created by the year 1989 as compared to the number of partnerships initiated in 1985. 
Factors Contributing to the

Surge in School/College

Partnerships

As with so many initiatives in education, the heightened interest in high school/college partnerships cannot be traced to a single trend, event, group, or organization. Several factors have combined to spur the current growth of partnerships: (a) demographic trends support from higher education, (c) support from private foundations, and (d) federal support. This section discusses the infiuence of those factors and closes with a discussion of the interest expressed by many of the partnerships in improving the access and success of minority and disadvantaged students in postsecondary education.

Demographic trends. According to demographic data, in the 15 years between 1285 and 2000 the U.S. population is projected to increase by $12.3 \%$. Nearly $60 \%$ of this projected growth will occur among minority populations, with an anticipated increase of 23.08 for Blacks, 45.08 for Hispanics, and 48.48 for other minority groups, compared to a 6.58 increase in the White population (Western Interstate Commission for Higher Education [WICHE], 1989). Blacks, Hispanics, and Native Americans are expected to make up nearly $40 \%$ of all 18-to 24-year-olds by the year 2025 (Mingle, 1987, p. ix).

This increase in the proportion of minorities in the general population and in the public schools has not, 
however, been matched by significant increases in postsecondary enrollments. In 1990, while $16 \%$ of public school children were Black, $12 \%$ Hispanic, and $3 \%$ Asian, the minority enrollment in postsecondary education was 98,68 , and 48 Black, Hispanic and Asian respectively (U.S. Department of Education [USDE], 1993, p. 114).

other findings have pointed to the inequality in college participation and enrollment among Black, Hispanic and Native American students, on the one hand and White students on the other hand. The college participation rate of Black/Hispanic college-age youth peaked in the mid-1970s and has declined since then. While total minority enrollment in postsecondary institutions increased 218 from 1976 to 1984 (nearly three times the rate of Whites) (Mingle, 1987), most of this increase sccurred before 1980. From 1980 to 1984, Black college enrollment in the United States actually declined, as did that of Native Americans (Mingle, 1987, p. ix). Between 1975 and 1985 the rate of Hispanic college enrollment declined from 518 to $47 \%$ (American Council on Education and Education Commission of the states [ACE/ECS], 1988). In that same period the college enrollment of Blacks dropped from $48 \%$ to 448 .

In addition, minority student enrollment has been disproportionately distributed throughout postsecondary institutions. Minorities constitute 24.48 of the enrollment in two-year institutions and 18.18 of the enrollment in 
four-year institutions (USDE, 1993). The representation of minorities in graduate and professional higher education drops even more dramatically compared to their representation in undergraduate higher education. For example, Blacks, who make up $13 \%$ of the college-age population, are $9.5 \%$ of all undergraduates and only $4.8 \%$ of graduate students (Mingle, 1987). However, between 1990 and the year 2000, postsecondary education enrollments of Asian and Hispanics are projected to grow more rapidly than are the enrollments of mites and Blacks. Projected increases in postsecondary education enrollments by ethnic groups between 1990 and the year 2000 include an increase of $8 \%$ for Whites, $19 \%$ for Blacks, $43 \%$ for Hispanics, and $38 \%$ for Asians. The increases in the numbers of minority students attending elementary and secondary schools and their projected increases within the college age population have, more than any other factor, prompted the involvement of higher education institutions in the creation of school/college partnerships. Minority populations constitute a significant portion of the future clientele of these colleges and universities. The higher education community is increasingly concerned with providing access for these students and is searching for ways to assist them to succeed.

Support from higher education. Colleges and universities, are in a unique position to assist in the 
development of collaborative school/college ventures. According to Gross (1988), higher education institutions possess critical elements that facilitate the creation of partnerships--academic departments with faculty who educate future teachers, offices of external affairs and development (through which fund raising can take place), and alumni and citizen groups eager to participate in educational partnerships. Colleges and universities can use these resources to facilitate the creation of academic relationships with secondary schools, community colleges, and business and community agencies.

The Western Interstate Commission for Higher Education (WICHE) (1989) described these opportunities in its publication, "A Crucial Agenda: Making Colleges and Universities Work Better for Minority children." In this document WICHE concluded that while attrition among minority students exists at each level of education (elementary, secondary, undergraduate, and graduate), the attrition rate at the transition points between levels is the key area for intervention. To minimize this student attrition, the commission suggests that schools at each level improve the preparation and motivation of students for the next level. At the same time, schools must also reach out to students at lower levels through cooperative programs. WICHE encouraged the schools and colleges in the 15 states under its jurisdiction to undertake such programs and to "cooperate, 
rather than function as a discrete set of separate parts" (p. 3).

The interest and support for school/college partnexships noted by WICHE (1989) and others have come from many quarters. Several states, most notably Minnesota and Florida, now require their colleges and local school districts to negotiate concurrent enrollment plans that allow high school students to take college classes. National and regional professional education associations have joined and in some cases lead the call for collaborations and partnerships between schools $\mid$ and colleges. (Among these associations are the National Association of Secondary School Principals, the American Association of Community and Junior Colleges, the American Association for Higher Education, the Allerican Council on Education, the Council of Chief state school officers, the Education Commission of the States, and the State Higher Education Executive officers.) In order to support the success of all partnerships and focus on the critical need to promote minority access to higher education, the American Association for Higher Education (AAHE) has institutionalized an office of School/College collaboration. That office administers the community compacts initiative funded by the Pew Charitable Trusts and sponsors yearly conferences on school/college collaboration. 
Support from private foundations. Private foundations have invested millions of dollars to encourage school/college partnerships. As noted above, the Pew Charitable Trusts recently funded a $\$ 10$ million networle of collaboratives under its "Community compacts for student Success," an initiative that has focused on the formation of multi-institutional partnerships to increase the enrollment and persistence of minority students in higher education and promote institutional reform in 10 metropolitan areas.

Another private foundation active in the promotion of collaboratives has been The Ford Foundation. Alarmed by the small number of urban community college students receiving baccalaureate degrees, The Ford Foundation in 1983 began a series of initiatives to assist two-year institutions prepare their students for four-year programs. Its first initiative was Networks/The National Center for Urban Partnerships, an entity that served as a racilitating agency to assist two and four-year colleges establish collaboratives to increase the number of urban, often minority, students receiving associate and baccalaureate degrees. The Ford Foundation also supported a second initiative, the Urban Community college Transfer Opportunities Program (UCC/TOP), a consortium of 23 two-year colleges working closely with four-year institutions to identify and support students interested in transferring from community colleges to four-year institutions. As a 
result of that effort 23 community college consortia formed collaborations with secondary schools.

These two Ford-sponsored initiatives soon made it clear that increasing the number of two-year and four-year college graduates in any urban community was a challenging enterprise, requiring the attention and support of the entire community. Thus, in 1989 The Ford Foundation with the assistance of The Fund for the Improvement of Postsecondary Education (FIPSE), jointly sponsored "Citywide Transfer," an effort to create consortia formed by representatives from business, community based organizations, and government as well as local schools and colleges. Fifteen cities applied for $\$ 25,000$ Ford Foundation planning grants earmarked to form local teams composed of representatives of schools, colleges, community and business organizations. With the assistance of staff from the National Center for Urban Partnerships, these teams were to develop plans whose goal would offer practical and effective assistance to minority and disadvantaged students in order to improve their academic preparation and increase their ability to enroll in the postsecondary institutions of their choice.

The Carnegie Corporation has also been active in the collaboration arena. Most notable has been the Corporation's funding of the Yale-New Haven Teachers' Institute, a joint effort of the Yale University and the New 
Haven Public schools to strengthen teaching and learning in local middle and high schools with minority populations of more than $80 \%$. The Institute is a joint effort integrating curriculum development with intellectual renewal for teachers in the schools. The Institute also serves as an interschool and interdisciplinary forum for teachers to work together on new curricula. Each participating teacher becomes an Institute Fellow and prepares a curriculum unit to be taught the following year. Teachers have primary responsibility for identifying the subjects that the Institute addresses. Studies of this program have shown that it increases teacher preparation in their own disciplines, raises morale, heightens the expectations for students, and enhances student performance.

carnegie has also been supportive of other efforts to facilitate collaboration and the creation of partnerships. The Carnegie Corporation funded the production of Linking Schools and Colleges: Guide to Partnerships and National Directory (Wilbur \& Lambert, 1991), which was undertaken with the cooperation of a distinguished group of professional education organizations representing a cross section of the education continuum, including the American Association for Higher Education, the National Association of Secondary School Principals, and the American Association of Community and Junior Colleges. David Hamburg, president of the Carnegie Corporation of New York, declared in the 
Introduction to the Guide that Carnegie and other cooperating organizations are "making a difference in student achievement" (p. v). He made an appeal for "every college and university to have a strong substantive relationship with schools in their geographic area" (p. v). This document has become one of the most respected guides in the field.

Federal support. In 1965 the federal government, on the assumption that improved education could reduce poverty and unemployment, launched three programs designed to increase the college going opportunities of low income and disadvantaged youngsters. The three programs, Upward Bound (UB), student support services and Talent search came to be known as the Federal TRIO programs. These programs were created as part of former president Lyndon Johnson's "var on Poverty," initially under the direction of the office of Economic Opportunity; in subsequent years, the programs were transferred to the U.S. Department of Education. The overall mission of these programs has been to improve the preparation and access to higher education for academic and economically disadvantaged students. TRIO programs served 3,261 students in 1965 when they were founded and have since grown to enroll 643,341 students in 1993. Likewise, funding for TRIO has increased from $\$ 6$ million in 1965 to $\$ 418.1$ million in 1993. 
The programs cover a significant portion of low income students in the education pipeline and have served as a bridge to higher education for minority and disadvantaged students. Talent search attempts to motivate middle school and high school students to attend college and assists students and their parents in the completion of financial aid and college admission applications. Upward Bound provides intensive academic and personal support to students From 9 th through 12th grade. Those services include academic instruction in a special 6-8 week summer program at the sponsoring colleges, tutorial assistance and social support throughout the academic year as well as the opportunity to take college courses during the 12th grade. Student Support Services makes available academic counseling: remedial instruction; tutoring and personal support from professionals familiar with the difficulties encountered by low income and minority students on college campuses.

It should be noted that although they have retained their original name, the TRIo programs have expanded to now include six programs. The new additions are: (a) the Educational opportunity Centers, which are college information centers serving displaced and underemployed workers; (b) The Ronald E. McNair Post-Baccalaureate Achievement Program, which encourages minority and low income undergraduates to consider careers in college 
teaching and preparation for doctoral study. This program extends research opportunities to the participating students and their faculty mentors; and (c) Upward Bound Math and Science Centers. These regional centers, initiated in 1993, are designed to offer intensive instruction in math and sciences and stress the mentoring of participating students by professionals working in the sciences. It will also make available research opportunities for participating students. The TRIO programs have influenced school/college collaboration in several ways. The programs, which serve middle and high school students (Talent Search and Upward Bound), have forged individual collaborative relationships with the schools their students attend. In many cases they were the first college programs to serve as advocates for the college enrollment of disadyantaged and minority populations. Upward Bound in particular requires cooperation and support from the school districts attended by its student members. Although most UB programs are administered by colleges and universities, the support of the client schools has been required as a condition to funding.

The success of TRIO has been unique, especially given the academically disadvantaged population it serves. Upward Bound programs have been found to have a beneficial impact on the aspirations, postsecondary progress and graduation rate of its participants. The major research study of UB 
conducted by Triangle Research Institute (Burkheimer, Riccobono, \& Wisenbaker, 1979) concluded that 918 of UB graduates entered postsecondary insțitutions and were more than twice as likely to enroll in a four-year college than students in the control group. These graduates took greater advantage of financial aid and were four times as likely to have earned a baccalaureate degree compared to non-Upward Bound participants.

Likewise, the student support Services program, which was evaluated by the Systems Development Corporation (Coulson, Bradford, \& Kayne, 1981), compared the performance of Support Services students to a control group of equal size from the same institutions. This study found not only was the support services program important to the participating students, but students who received the services program were 2.26 times as likely to complete their first year of college compared to students who did not receive those services.

Many school/college collaboratives have recognized the significance of TRIO in the school/college articulation continuum. At the very least, TRIo programs have demonstrated that nontraditional populations can be successful in overcoming the obstacles to college enrollment and, that once in college, students can succeed. Stoel, Tognery, and Brown (1992) recognized the influence of Upward Bound in their guide to model partnerships. They asserted 
that UB and other efforts of the 1960s helped form a set of assumptions about what is needed to help minority and low income students succeed in their preparation for and transition to postsecondary education. These "important truths" are articulated by stoel, Tognery, and Brown (1992, p. 1) as follows:

1. If properly educated and supported, minority students and students from poor homes can be as successful in school and college as anyone else.

2. Despite evidence that it is best to start early in preventing problems, it is never really too late to reach young people.

3. When colleges become involved with young people and the schools they attend, pronounced benefits accrue not only to students but to both institutions.

The Influence of the Reform Agenda

While in the past the involvement of non-K-12 school agencies in the policies and procedures of public schools was relatively infrequent, the public and professionals alike have conceded that American public schools cannot accomplish reform on their own. Other constituents must be involved, including colleges, corporations, businesses, communities, and government (Gross, 1988).

A Nation at Risk (National Commission on Excellence in Education, 1983), the report that spearheaded the recent 
educational reform movement, does not mention partnerships explicitly. But the reform activities following this report have placed great emphasis on inter-institutional collaboration as a means to improve the quality and coordination of services to students and to share and preserve increasingly scarce resources.

The role of partnerships as vehicles for change also has received endorsement from well-respected practitioners. Goodlad (1984), in particular, has become one of the foremost proponents of partnerships as a vehicle for school improvement. He argued that partnerships and collaboratives should not be viewed as an end in themselves, but rather as a vehicle for the reconstruction of the educational system. Goodlad has initiated an ambitious college/school collaboration that concentrates on "the education of educators" and seeks ways to improve the system. His "National Network for Educational Renewal" includes 13 partnerships of school districts and universities, each focusing on the simultaneous improvement of both preparation and practice, and the development of a national network to link these partnerships in common research and school improvement efforts (Gross, 1988, p. 18). Goodlad believed those partnerships to be critical, and that school improvement and better preparation of educators should go hand in hand. In his book, Teachers for Our Nation's Schools, Goodlad (1990) outlined a specjefic plan for the 
upgrading of teacher preparation and calls for simultaneous school improvement and the establishment of a clear agenda for change. Believing that better schools depend upon better trained educators, Goodlad argued a key element in school improvement is the creation of exemplary school-based training sites in which prospective educators can observe, learn and practice good techniques. The ultimate partnership arrangement involves mutual responsibility for the total education of educators.

\section{Priorities of Recent}

Partnerships

Wilbur and Lambert (1991) concluded that the primary focus of recent partnerships can be found in one of the following four categories: (a) programs and services for students; (b) programs and services for educators; (c) coordination, development, and assessment of curriculum and instruction; and (d) programs to mobilize, direct, and promote sharing of educational resources. Programs and services for students were singled out as the primary focus by $43 \%$ of the respondents, the largest percentage by far. Faculty programs, resource sharing programs, and curriculum and instruction programs trailed with $33 \%, 13 \%$, and $11 \%$ respectively (p. 2) .

Among the partnerships created in order to increase programs and services for students, those that involve minority and disadvantaged students are a priority for 
college presidents and school superintendents. This may be true in part because demographic projections suggest that minorities and adults will dominate the growing sectors of the student population, and that the size of traditional college populations will diminish accordingly (Astin, 1982; Levine, 1989 ; Richardson, 1991; .

Mickelson et al. (1988), in their national survey of college partnerships, found that university presidents believed that minority and disadvantaged students benefited more than any group from the school/college partnerships that had been created. In fact, they rated the benefits to these students to be greater than to any other group affected by the partnerships.

The challenges and the calls for solutions presented by demographic trends and the need services and programs for minority students have been underscored in analysis such as that provided by Hodgkinson (1985), who noted that:

The rapid increase in minorities among the youth population is here to stay. We need to make a commitment as educators to see that all our students in higher education have an opportunity to perform academically at a high level. There will be barriers of color, language and attitude. - The task will be not to lower the standards but to increase the effort. . . Their numbers are now so large that if they do not succeed all of us will have diminished futures. That is the new reality. (p. 18)

Given this urgency, the creation of more educational opportunities and greater access to higher education for minority students has become a major policy priority of the 
higher education community. Since the American Council on Education and the Education Commission of the states (ACE/ECS, 1988) produced their report "One Third of a Nation," many other higher education organizations, college presidents, and state systems of postsecondary education have called for higher education institutions to assume a leadership role in addressing the under-enrollment and low number of graduating minorities in higher education.

The Literature on organizational Factors Affecting Partnerships

Partnerships are organizations, their characteristics match those used to describe organizations by Etzioni (1964):

organizations are social units deliberately constructed and reconstructed to seek specific goals. They are characterized by: 1) divisions of labor, power and communication responsibilities; 2) the presence of one or more power centers; 3 ) substitution of personnel. (p. 3)

Scott (cited in Hall, 1977) added to that definition:

organizations are defined as collectivities that have been established for the pursuit of relatively specific objectives on a more or less continuous basis. It should be clear however that organizations have distinctive features other than goal specificity and continuity. These include relatively fixed boundaries, a normative order, authority ranks, a communication system, and an incentive system which enables various types of participants to work together in the pursuit of common goals. (p. 21) 
Barnard, Weber, Marx, and Hall (cited in Hall, 1977)

have added definitions on organizations. They all have two

common themes: coordination and activity.

More recent definitions of organizations have added new

characteristics unique to twenty first century

organizations. According to Nanus (1992) they include:

their tendency to be multipurpose, serving the

needs of many constituencies. They are never

simply economic institutions or social

institutions, or political, artistic, environmental or any other single form of

institution; they are rather a melding of all or several of these types in different proportions. (p. 176)

Multi-purpose organizations that involve several

participants and constituencies demand, in turn, effective

leadership. The importance of leadership to these

organizations has been noted by Garner (1990) and Van de

Water (1989) who concluded that:

quality and stability in administration were the key ingredients to success in the partnerships he studied. Collaborative activity requires substantial attention from the administrative leadership who must pay attention to planning meetings, ensuring communication among participants, preparing and overseeing budgets, preparing material for review and approval of governance groups, and preparing funding requests. (p. 25)

The nature of the people involved in the leadership of the partnerships was a significant factor in Van de Water's findings. The leaders who had a broad (national)

perspective on initiating new initiatives, shared power and empowered others were the most successful. This study 
returns to the literature on partnerships as organizations and the importance of leadership in chapter $v$.

\section{The Success of Collaboratives}

Given the growth in their numbers and the importance attributed to schooi/college collaboratives, what do we know about their success in meeting their objectives? Otterioourg and Adams (1989), who surveyed some two dozen school/business partnerships to ascertain planning, implementation and evaluation priorities, found that only a quarter of the programs reported used outcome data to measure effectiveness. In general, the authors concluded that evaluation of partnership programs is at an elementary stage. According to Trubowitz, Duncan, Fibkins, Longo, and Sarason (1984), because many of these efforts have not achieved their objectives, there is litt.le inclination to publicize their lackluster results. For those collaboratives that have been somewhat successful, the factors contributing to their success are minimally described, making it difficult to track the ingredients of their progress. Some studies do, however, point in the right direction.

Literature on the characteristics of Successful collaboratives

In the last decade, as the impetus to create collaborations has increased, a number of scholars and 
practitioners have identified factors that may be fundamental to the long-range success of partnerships. A review of this literature shows some clear patterns in those characteristics associated with successful partnerships. Van de Water (1989) anả Gomez, Bissell, Danziger, and Casselman (1990) have noted the literature consistently identified certain characteristics. The authors have grouped these characteristics into 10 areas. They include:

1. Proclamation of mutual self-interest and common goals. A clearly articulated and accepted statement of mutual self-interest and common goals appears to be a necessary starting point for building a successful collaborative. While the various parties to a collaborative effort may have personal or institutional interests in participating, it is important that they identify and ayiree on a common focus for the partnership. They must also understand how each will gain from the commitment (Galligani, 1987, p. 15; Martin, Mocker, \& Brown, 1986, p. 5 ; Sirotnik \& Goodlad, 1988, p. viii; Vivian, 1986, p. 62 Wilbur, Lambert, \& Young, 1988, p. vii) .

2. Collaborative activities must develop mutual trust and respect among members. Each participant must uniterstand the unique experience and perspective that others bring to the collaborative, and each must demonstrate a willingriess to work with the others on a professional basis (Galligani, 
1987, p. 15; Martin, Mocker, \& Brown, 1986, p. 17; Sirotnik \& Goodlad, 1988, p. 6; Vivian, 1986, p. 63).

3. Shared decision-making. Successful collaboratives uniformly stress the involvement of all parties in decisionmaking. This applies to all activities, including decisions concerning the focus of the collaborative's activities, the approach to be used, the allocation of resources, and the evaluation of results (Curry, 1980, p. 631; Galligani, 1987, p. 11; Gifford, 1986, pp. 91-93; Martin, Mocker, \& Brown, 1986, p. 11; Sirotnik \& Goodlad, 1988, p. 26; Vivian, 1986, pp. 59, 75) .

4. Establish a clear focus. Given the many complex issues that can be addressed, it is important to establish a clear focus with regard to the expected outcomes and scope of the collaboration isirubinik a Goodiad, 1988, p. 59; Vivian, 1986, p. 65; Wilbur, Lambert, \& Young, 1988, p. 41).

5. Pursuit of a manageable agenda. A parallel to establishing a clear focus is the need to limit activities. Because resources--both time and money--will always be finite, collaborative members must discipline themselves when setting their mutual agenda. Starting small and keeping the organizational elements as simple as possible appear to work best (Bailey, 1986, p. 21; Vivian, 1986, p. 63).

6. Commitment from top leadership. Because collaboration is often seen initially as peripheral to the 
core functions of each participating institution, it is necessary to have both the commitment and the involvement of top leaders from each of the participating entities. Leaders provide legitimacy to the undertaking, underscore its importance, and have the capacity to harness and commit resources (Bailey, 1986; p. 13; Galligani, 1987, p. 15; Gifford, 1986, pp. 84, 92; Intriligator, 1982, p. 16; Martin, Mocker, \& Brown, 1986, pp. 5, 18-20; Sirotnik \& Goodlad, 1988, p. 28; Vivian, 1986, p. 63; Wilbur, Lambert, \& Young, 1988, p. vii).

7. Adequate financial support. Adequate financial support is not only important to cover the costs of collaboration, it is also critical to the collaborative activity's credibility. When scarce resources are allocated to an activity, the message is clear that the laadership considers the activity important and worthy of financial investment (Martin, Mocker, \& Brown, 1986, p. 27; Sirotnik \& Goodlad, 1988, p. 28; Vivian, 1986, p. 63; Wilbur, Lambert, \& Young, 1988, p. vii).

8. Commitment to a long-term relationship. Changing the way that schools and colleges work together to address complicated issues requires years of patient work. Participants in collaboratives should understand that results are not likely to be immediate. Change will be slow and outcomes difficult to evaluate in the short-term 
(Bailey, 1986, p. 21; Gifford, 1986, pp. 4, 84, 91; Sirotnik \& Goodlad, 1988, p. 28; Vivian, 1986, p. 64).

9. Receptiveness to the dynamic and changing nature of collaboratives. Collaborative activity typically begins with a shared understanding of the problems but with less clarity about the ways to address them. The dynamic development of collaborative activities should be recognized as normal and should be encouraged (Galligani, 1987, p. 16; Martin, Mocker, \& Brown, 1986, p. 15).

10. Sharing of information. Because members of collaboratives typically have other full-time professional commitments, it is particularly important to ensure that all members are kept informed. The activities, experiences, and outcomes of the collaborative should be publicized and shared with the participating institutions and thie community at large, thereby maintaining support for the existence of the partnership's activities (Galligani, 1987, p. 16; Gifford, 1986, pp. 89-90, 96; Sirotnik \& Goodlad, 1988, p. 28).

Sunmary

The review of the literature on school/college partnerships confirms the growth and importance of collaboratives to the education community. Educational partnerships are generating increased expectations for their efficacy in the process of educational reform, social change 
and the improvement of services to students in both secondary and postsecondary institutions.

Partnerships have increased the participation of higher education with the K-12 public schools, business and government in comprehensive efforts to maximize limited resources and remove the obstacles to the successful participation of students in postsecondary institutions. Sirotnik and Goodlad (1988) noted that "a flood of partnerships" (p. vii) has covered the educational landscape.

With the realization that the future clients of the nation's colleges and universities will increasingly be found among ethnic minority groups, many colleges and universities are adapting to the characteristics of this changing student popliation. The creation of partnerships is pursued by these institutions as a strategy to overcome the obstacles that impede the successful enrollment and participation of minority and disacvantaged students in postsecondary education. Partnerships are designed to integrate the resources of $\mathrm{K}-12$ and postsecondary educational systems with foundations, government, business and community organizations to improve the academic preparation and college enrollment of minority students. Van de water (1989) and Gomez et al. (1990) have noted the consistency in which the literature on partnerships identifies some characteristics that contribute to the 
success of collaborative efforts. They include mutual self interest and common goals; mutual trust and respect; shared decision making; clear focus; manageable agenda; commitment from top leadership; financial support; long-term commitment; dynamic nature; and information sharing. The importance of these characteristics to the success of partnerships is supported by other authors (Bailey, 1986; Galligani, 1987; Gifford, 1986; Martin, Mocker, \& Brown, 1986; Sirotnik \& Goodlad, 1988; Vivian, 1986; Wilbur, Lambert, \& Young, 1988).

Despite the identification of factors that contribute to the success of individual partnerships, they have rarely been empirically examined. The few researchers who have inquired about the partnership phenomena (Comer, 1981; Mickelson et al., 1988; Otterburg \& Adams, 1989) invariably call for more analysis of the outcomes and success factors. Still, little research is available on the success of comprehensive partnerships that focus on removing the obstacles to school and college access and student success. The present study examines the characteristics and success of those comprehensive partnerships for minority and disadvantaged students and explores the degree to which the success characteristics considered important in the literature have indeed affected the success of a small number of those partnerships. 
The next chapter details the research questions and the methodology used to conduct this study. It explains the characteristics of the partnerships studied, the research methodology selected, and the methods for data collection and data analysis. It also lists the partnerships survey and discusses the interview protocol and the interviewees selected. 
CHAPTER ITII

\section{METHODOLOGY}

The literature not only reveals the development, importance and focus of the partnership movement in the education community, it also suggests that partnerships designed to increase the preparation, access and success of minority students may hold a key to increased college enrollments, the diversification of higher education and the integration of minorities into nontraditional professional work opportunities. It is imperative, therefore, that we learn as much as possible about the factors which make these partnerships successful as well as those that hinder thoi: success. The need for additional information regarding this issue gives this study added importance and raises the possibility that its findings will make a significant contribution to the field.

\section{Research Problem and Questions}

School/college partnerships have been created to increase the participation and success of minority and disadvantaged students in postsecondary education. In order to better understand whether these partnerships have been successful and the factors contributing to their success or 
shortcomings, the study: (a) Identified selected comprehensive partnerships which focus on the increased participation and success of minority and disadvantaged students in secondary and postsecondary education; (b) Identifiled those partnerships which are the most successful; and (c) Enumerated the factors affecting the success of these partnexships, with special attention to criteria noted in the lliterature on partnerships. The study focused on the following research questions

1. Outcomes of Partnerships: To what degree have school/college partnerships serving minority and disadvantaged students defined and achieved desired outcomes?

2. Relationship to Success: Characteristics

To what axtont have the partnerahips incoiporated selected "partnership success characteristics" identified in the literature, land to what extent have these characteristics|contributed to the partnerships' success?

3. Other Factors that contribute to success or

Failure: How do these factors affect the opportunities for the success of the partnerships?

\section{Sample}

The sample for this study consists of comprehensive multi-institutional partnerships. "Comprehensive" partnerships for the purpose of this study are those that 
involve several institutional levels. They typically include a school district or districts, a community or junior college, at least one four-year college or university, and community and business organizations. The partnerships represent a regional commitment and strategy to analyze institutional policies and practices and a recognition that community-wide support is needed for the success of these enterprises.

Comprehensive partnerships require a different level of collaboration, support and governance than the more limited cooperative arrangements between two entities (i.e., one college/one school). They are frequently created to produce large scale change in the numbers of minority and disadvantaged students who enroll and succeed in college. The partnerships to be studiad wore identiciad through a review of national directories and guides to partnerships (Baird \& Porter, 1991; Daly, 1985; Freeman, 1992; stoel, Brown \& Tognery, 1992; Wilbur \& Lambert, 1991; Wilbur, Lambert \& Young, 1988). A close review of these directories yielded an extensive list of comprehensive partnerships from a variety of locations (see Appendix A). Additional partnerships were identified through a search of the National School-College Partnership Electronic Data Base located at Syracuse University (Center for the study of Partnerships, 1994). A copy of the database search request and application is attached (see Appendix B). 
Characteristj.cs of the

Partnerships studied

only comprehensive school university partnerships focusing on increasing the minority enrollment and retention of minority and disadvantaged students through postsecondary education and which have endured for at least five years were studied. Partnerships that have demonstrated the ability to endure for at least five years were considered successful in surviving the early embryonic period of partnership formation. In addition, the partnerships selected had adopted the following characteristics and goals:

1. Multiple institutional level involvement: Involving schools, two-year colleges, four-year colleges and universities, parent, businesses and community organizations.

2. Written agreements, an explicit governance structure, and available financial support are three essential characteristics of successful partnerships identified in the literature.

3. Improved academic performance by high school students and special instruction and support (i.e., tutoring, coaching, college exposure, test tałing skills, and financial aid assistance). These activities are indicative of the comnitment to improve academic skills in preparation for postsecondary education and demonstrate the ability to arrange for the provision of essential services. 
4. Increased college enrollment and success for minority and disadvantaged students. Provide academic, financial, and social support services to college students. These characteristics evidence commitment to the ultimate goal of increased college enrollment and success and demonstrate the ability to arrange for the provision of essential services at the postsecondary level.

5. College participation in a wide-range of majors and areas of concentration. This characteristic signifies that the partnership is committed to the goal of postsecondary enrollment without regard for academic discipline or professional interest.

\section{partnerships Identified}

The initial step in this study was the j.dentification of the universe of desired partnerships. To accomplish that task the researcher sought available directories of partnerships published by individuals, national foundations and national education organizations. An ERIC search and a database search by the National center for the study of Partnerships were also conducted to identify all possible partnerships that met the criteria of this study. These criteria will be addressed later in this chapter. A brief description of the directories utilized follows:

1. Wilbur, Lambert, and Young (1988): School College Partnerships: A Look at the Major National Models. The information in this monograph was obtained via the National 
Survey of School-College Partnerships, conducted in August 1986. The survey elicited more than 1,000 responses from schools and colleges about a wide variety of partnership activities. A description of each program was written at Syracuse University and forwarded to the appropriate institution for content approval.

Major Program Categories in this directory include the following: In service Education/Faculty Development; Academic Alliances; Programs offering College Jevel Instruction to Precollege Students; Minority, Disadvantaged and "At Risk" Students; Gifted and Talented students; Articulation Programs; Research on Teaching and Learning; Adopt a School Programs; and Consortia Coordination of Collaborative Activities.

2. Baird and portor (1991), partrors in Educetion: $\lambda$ Directory of partnerships Between Independent colleges and Universities and America's Schools. The Foundation for Independent Higher Education (FIHE) and the National Institute or Independent Colleges and Universities (NIICU) initiated a survey of their combined membership (946 independent colleges and uriversities) to collect information on partnerships with elementary and secondary schools. Of the 650 responses, 361 independent colleges and universities (56\%) indicated that they had at least one such partnership in place, which were listed and described by their state of residence. A list of programs designed to 
promote higher minority graduation rates in Mathematics and Science was included at the end of the monograph.

3. Freeman (1992), Power in the Pipeline: New Wave of Multicultural Education Partnerships. This publication was designed by the Association of Governing Boards to stimulate new endeavors in higher education partnerships with secondary, middle and elementary schools. This compendium has a synopsis on each of 101 innovative and successful preK-12 access and diversity projects nationwide. Categories included were preschool programs; elementary and middle school programs; programs for high school students; mentorship programs; programs at historically Black and predominantly Hispanic and American Indian colleges; corporate-supported programs; and public and private community nartnerships.

4. Stoel, Tognery, and Brown (1992), What Works: School College Partnerships to Improve Poor and Minority Students Achievement. The American Association for Higher Education's guide to "model" partnerships for student success, although not all inclusive, described partnerships representative of certain categories of programs believed to be particularly significant in improving school and college success for poor and minority students. Twenty-three partnerships were included in the following categories: Early Identification Programs; Dropout Prevention Programs; Programs that Focus on Curriculum and Teaching; Professional 
Paths Programs; College Access Programs; Programs as Schools on College Campuses; and Comprehensive Programs.

5. Wilbur and Lambert (1991), Linking America's Schools and Colleges: Guide to Partnerships and National Directory. Wilbur and Lambert (1991) surveyed colleges and universities nationwide in order to learn about the nature and extent of their partnerships with schools. The responses of 1,286 colleges and universities, when compared with a similar survey conducted in 1987, revealed a marked increase in the number and scope of partnerships. Of the colleges and universities responding to the wilbur and Lambert survey, 882 were public and 404 were private. These school/college partnerships were grouped by wilbur and Lambert (1991) into the following categories: (a) programs and services for students; (b) programs and services for educators; ( $($ ) coordination, development, and assessment of curriculum and instruction; and (d) programs to mobilize, direct, and promote sharing of educational resources.

In addition to the aforementioned directories, a search was requested of the Database of National Center for the Study of Partnerships at Syracuse University (Center for the Study of Partnerships, 1994). Four parts of the database were searched for evidence of partnerships that met the criteria for this study:

Part 1. Programs and services for students. Part 2. Programs and services for educators. 
Part 3. Coordination, development and assessment of curriculum and instruction.

Part 4. Programs to mobilize, direct and promote sharing of educational resources.

The search adhered to the following applicable search parameters within the database groups: Serving underrepresented and at-risk populations; college courses for high school students; middle colleges and early colleges; regional and statewide inter-institutional articulation councils and agreements; coordinating councils and consortia for school improvement. The National Center's database search produced four printouts with hundreds of partnerships and collaboratives.

\section{Partnerships studied}

"Comprehensive" partnerships, or those that involve several segments of educational organizations, and are sometimes called "intersegmental," were the focus of this study. These partnerships frequently bring together a school district or districts, a community or junior college, at least one four-year college or university, and community and business organizations. They represent a regional commitment and strategy to analyze institutional policies and practices; at the same time they seek the support of their many participants in order to achieve commonly desired goals. Such partnerships require a different level of collaboration, support, and governance than the more limited 
cooperative arrangements between two entities (i.e., one college/one school, or one college class/one school class). The comprehensive partnerships in this study are important subjects for analysis because they were created to produce significant change in the ability of public schools and postsecondary institutions to increase the number of minority and disadvantaged students who enroll and succeed in college.

Those comprehensive partnerships that focus on minority and disadvantaged students and have endured for at least five years were studied because they were considered successful in surpassing the early formative period of partnership formation. The study surveyed all such identifiable comprehensive partnerships in the U.S. and conducted case studies on two of tham.

Criteria applied to select the partnerships. Partnerships demonstrating the following characteristics were identified from the database and the directories mentioned above:

- Partnerships in existence for five years or more;

- Partnerships involving multiple institutional levels and community-wide support (such as schools, two-year colleges, four-year colleges and universities, parents, businesses and community organizations);

- Partnerships demonstrating access to financial and other resources; 
- Partnerships promoting improved acaderic performance by high school students. May provide special instruction and support (i.e., tutoring, coaching, college exposure, test taking skills, and financial aid application assistance);

- Partnerships promoting increased college enrollment and success for minority and disadvantaged students. May facilitate and encourage the provision of academic, financial, and social support services to college students;

- Partnerships promoting college participation in all major areas of study rather than in one specialization. Twenty-one partnerships meeting the criteria for this study were identified in the review of the aforementioned guides, directories and databases. They are identified with a listing of their host organizations: the scope of the partnership, and the source of the information in Table 1. Telephone calls were made to each of the 21 partnerships identified above to request their cooperation and the names of three key informants who could respond to the survey. During this process it was discovered that 5 of the 21 partnerships had been discontinued. Lack of funding was the primary reason for the termination of all these partnerships. Their names and the reason for their termination are included in Table 2 . 
Table 1

Partnerships in this study

\begin{tabular}{|c|c|c|c|}
\hline NAME & HOST & SCOPE & SOURCE \\
\hline The Think Tank & $\begin{array}{l}\text { Maricopa Community } \\
\text { Colleges }\end{array}$ & $\begin{array}{l}\text { Multi-institutional } \\
\text { collaborative with } \\
\text { community involvement }\end{array}$ & $\begin{array}{l}\text { Stoel, Tognery, and } \\
\text { Brown (1992, p. 76) }\end{array}$ \\
\hline $\begin{array}{l}\text { The Toledo School } \\
\text { College Compact }\end{array}$ & $\begin{array}{l}\text { State University at } \\
\text { Toledo }\end{array}$ & $\begin{array}{l}\text { Multi-institutional } \\
\text { collaborative with } \\
\text { community involvement }\end{array}$ & $\begin{array}{l}\text { Sioel, Tognery, and } \\
\text { Brown (1992, p. 76) }\end{array}$ \\
\hline $\begin{array}{l}\text { Hispanic Student } \\
\text { Success Program }\end{array}$ & $\begin{array}{l}\text { Hispanic Association } \\
\text { Colleges and } \\
\text { Universities San } \\
\text { Antonio, Texas }\end{array}$ & $\begin{array}{l}\text { Multi-institutional } \\
\text { collaborative with } \\
\text { community involvement }\end{array}$ & $\begin{array}{l}\text { Stoel, Tognery, and } \\
\text { Brown (1992, p. 78) }\end{array}$ \\
\hline Project Prime & $\begin{array}{l}\text { Arizona State } \\
\text { University }\end{array}$ & $\begin{array}{l}\text { Multi-institutional } \\
\text { collaborative with comm } \\
\text { involvement }\end{array}$ & $\begin{array}{l}\text { Stoel, Tognery, and } \\
\text { Brown (1992, p. } 81)\end{array}$ \\
\hline $\begin{array}{l}\text { Pace Liberty } \\
\text { Partnerships Program }\end{array}$ & Pace University & $\begin{array}{l}\text { Multi-institutional coll } \\
\text { with com support }\end{array}$ & $\begin{array}{l}\text { Wilbur and Lambert } \\
\text { (1991, p. 7) }\end{array}$ \\
\hline $\begin{array}{l}\text { Tell Them we are } \\
\text { Rising }\end{array}$ & Temple University & $\begin{array}{l}\text { Multi-institutional } \\
\text { collahoration with com } \\
\text { involvemen! }\end{array}$ & $\begin{array}{l}\text { Wilbur and Lambert } \\
\text { (1991, p. 11) }\end{array}$ \\
\hline $\begin{array}{l}\text { New Partnerships for } \\
\text { Work and Leaming }\end{array}$ & $\begin{array}{l}\text { Burlingten Community } \\
\text { College }\end{array}$ & $\begin{array}{l}\text { One higher education } \\
\text { institution, community } \\
\text { and schools }\end{array}$ & $\begin{array}{l}\text { Wilbur and Lambert } \\
\text { (1991, p. 14) }\end{array}$ \\
\hline $\begin{array}{l}\text { Cleveland Initiative in } \\
\text { Education }\end{array}$ & $\begin{array}{l}\text { Case Western Reserve } \\
\text { University }\end{array}$ & $\begin{array}{l}\text { One institution schools } \\
\text { and community }\end{array}$ & $\begin{array}{l}\text { Wilbur and Lambert } \\
\text { (1991, p. 18) }\end{array}$ \\
\hline ACCESS 2000 & $\begin{array}{l}\text { Loyola University of } \\
\text { Chicago }\end{array}$ & $\begin{array}{l}\text { Several higher education } \\
\text { institutions, schools, } \\
\text { community }\end{array}$ & $\begin{array}{l}\text { NIICU Directory of } \\
\text { Partnerships } \\
\text { (Baird \& Porter, } \\
\text { 1991, p. 16) }\end{array}$ \\
\hline The Boston Compact & $\begin{array}{l}\text { Boston School College } \\
\text { Collaboration }\end{array}$ & $\begin{array}{l}\text { Multi-institutional coll } \\
\text { business and comm } \\
\text { support }\end{array}$ & $\begin{array}{l}\text { IICU Directory of } \\
\text { Partnerships } \\
\text { (Baird \& Porter, } \\
\text { 1991, p. 22) }\end{array}$ \\
\hline $\begin{array}{l}\text { Colorado VIP Student } \\
\text { motivation and } \\
\text { recruitment program }\end{array}$ & $\begin{array}{l}\text { University of Denver/ } \\
\text { West High School }\end{array}$ & $\begin{array}{l}\text { Multi higher education } \\
\text { institutional/multi } \\
\text { secondary }\end{array}$ & $\begin{array}{l}\text { NIICU Directory of } \\
\text { Partuerships } \\
\text { (Baird \& Porter, } \\
\text { 1991, p. 8) }\end{array}$ \\
\hline
\end{tabular}


Table 1

Partnerships in this study (continued)

\begin{tabular}{|l|l|l|l|}
\hline NAME & HOST & SCOPE & SOURCE \\
\hline $\begin{array}{l}\text { Education Consortium } \\
\text { of Central Los Angeles }\end{array}$ & $\begin{array}{l}\text { University of Southern } \\
\text { California }\end{array}$ & $\begin{array}{l}\text { Multi-institutional } \\
\text { multischool comm } \\
\text { collaboration }\end{array}$ & $\begin{array}{l}\text { NIICU Directory } \\
\text { (Baird \& Porter, } \\
\text { 1991, p. 8) }\end{array}$ \\
\hline $\begin{array}{l}\text { Improving High School } \\
\text { Transition for Inner } \\
\text { City Students/ } \\
\text { University Scholars } \\
\text { Program }\end{array}$ & $\begin{array}{l}\text { Columbia College, } \\
\text { Northern Illinois } \\
\text { University, Crane and } \\
\text { View High Schools }\end{array}$ & $\begin{array}{l}\text { Two higher education } \\
\text { two secondary } \\
\text { institutions }\end{array}$ & $\begin{array}{l}\text { NIICU directory } \\
\text { (Baird \& Porter, } \\
\text { 1991, p. 15) }\end{array}$ \\
\hline $\begin{array}{l}\text { Black Student } \\
\text { Achievement Program }\end{array}$ & $\begin{array}{l}\text { Hood College } \\
\text { Maryland, Mt St }\end{array}$ & Multi-institutional coll & $\begin{array}{l}\text { NIICU Dirsctory } \\
\text { (Baird \& Porter, } \\
\text { 1991, p. 21) }\end{array}$ \\
\hline $\begin{array}{l}\text { Minnesota Minority } \\
\text { Education Partnership }\end{array}$ & St John's University & $\begin{array}{l}\text { Multi-institutional, } \\
\text { community support }\end{array}$ & $\begin{array}{l}\text { NIICU Directory } \\
\text { (Baird \& Porter, } \\
\text { 1991, p. 27) }\end{array}$ \\
\hline $\begin{array}{l}\text { San Antonio Education } \\
\text { Partnership }\end{array}$ & St Mary's University & $\begin{array}{l}\text { Multi-institutional coll } \\
\text { community support, } \\
\text { sciool suppori }\end{array}$ & $\begin{array}{l}\text { NIICU Directory } \\
\text { (Baird \& Porter, } \\
\text { 1991, p. 52) }\end{array}$ \\
\hline $\begin{array}{l}\text { Fairfax County Public } \\
\text { School Partnership }\end{array}$ & $\begin{array}{l}\text { Roanoke College } \\
\text { (Roanoke Virginia) }\end{array}$ & $\begin{array}{l}\text { Multi-institutional, } \\
\text { multischool }\end{array}$ & $\begin{array}{l}\text { NIrCU Dirzctory } \\
\text { (Baird \& Porter, } \\
\text { 1991, p. 54) }\end{array}$ \\
\hline $\begin{array}{l}\text { The Bedford } \\
\text { Achievement }\end{array}$ & $\begin{array}{l}\text { Lake Harbor } \\
\text { University }\end{array}$ & $\begin{array}{l}\text { One college schools and } \\
\text { minority community } \\
\text { support (Urban league) }\end{array}$ & $\begin{array}{l}\text { NIICU Directory } \\
\text { (Baird \& Porter, } \\
\text { 1991, p. 55) }\end{array}$ \\
\hline $\begin{array}{l}\text { Haywood County } \\
\text { Public/Private } \\
\text { Educational Compact }\end{array}$ & $\begin{array}{l}\text { Haywood Community } \\
\text { College } \\
\text { Colleges, Multiple } \\
\text { Schools; Minority } \\
\text { Disadvantaged/At Risk } \\
\text { Corporate Parental and } \\
\text { Community Involvement }\end{array}$ & $\begin{array}{l}\text { Center for the Study } \\
\text { of Partnerships } \\
\text { (1994); Database } \\
\text { Search Syracuse } \\
\text { University }\end{array}$ \\
\hline
\end{tabular}


Table 1

\section{Partnerships in this study}

(continued)

\begin{tabular}{|c|c|c|c|}
\hline NAME & HOST & SCOPE & SOURCE \\
\hline $\begin{array}{l}\text { Simmons College- } \\
\text { School Consortium }\end{array}$ & Simmons College & $\begin{array}{l}\text { Consortia Multiple } \\
\text { Colleges Multiple } \\
\text { Schools Minority } \\
\text { Disadvantaged At/Risk } \\
\text { Enrichment Programs } \\
\text { Upward Bound Faculty } \\
\text { Exchanges Tutoring/ } \\
\text { Volunteer Program }\end{array}$ & $\begin{array}{l}\text { Center for the Study } \\
\text { of Partnerships } \\
\text { (1994); Syracuse } \\
\text { University }\end{array}$ \\
\hline $\begin{array}{l}\text { Community Alliance to } \\
\text { Support Education }\end{array}$ & $\begin{array}{l}\text { University of } \\
\text { Charleston }\end{array}$ & $\begin{array}{l}\text { Comprehensive Local } \\
\text { Partnerships College } \\
\text { Courses for HS students } \\
\text { Minority Disadvantaged } \\
\text { At/Risk Enrichment } \\
\text { Programs }\end{array}$ & $\begin{array}{l}\text { Center for the Study } \\
\text { of Partnerships } \\
\text { (1994); Syracuse } \\
\text { University }\end{array}$ \\
\hline
\end{tabular}

Table 2

\section{Partnerships that Terminated Before the Study Began}

\begin{tabular}{|l|l|}
\hline \multicolumn{1}{|c|}{ Partnership } & \multicolumn{1}{|c|}{ Reason for Termination } \\
\hline $\begin{array}{l}\text { New Partnerships for Work and } \\
\text { Learning }\end{array}$ & New Jersey state Challenge Grant expired. \\
\hline $\begin{array}{l}\text { Haywood County Public/Private } \\
\text { Educaticnal compact }\end{array}$ & $\begin{array}{l}\text { Was funded by businesses. Terminated when the funding } \\
\text { stopped. A "Shadow Business Person" program remains. }\end{array}$ \\
\hline Cleveland Initiative in Education & $\begin{array}{l}\text { Business funded scholarship program. Students were to } \\
\text { claim scholarships if they performed in school. \$1 million } \\
\text { was put in escrow. Only \$80,000 was claimod. The funds } \\
\text { were transferred to another Cleveland scholarship program. }\end{array}$ \\
\hline Black Student Achievement Program & $\begin{array}{l}\text { This program was funded by the state of Maryland. Lost } \\
\text { state funds } 6 / 93 \text {. May seek additional funding in the future. }\end{array}$ \\
\hline $\begin{array}{l}\text { Community Alliance to Support } \\
\text { Education }\end{array}$ & $\begin{array}{l}\text { Terminated in April } 1994 . \text { The college funded the program } \\
\text { and was in the alliance for six years. Reduced financial } \\
\text { resources and the fact that it did not fit the priorities of the } \\
\text { college led to the termination }\end{array}$ \\
\hline
\end{tabular}


Research Methodology

The research methodology used in this study was guided by the sample of participating partnerships and the research questions. The review of directories and databases on the existence of comprehensive multi-institutional partnerships led to the identification of 21 partnerships that net the criteria for participation in this study. Five of those partnerships were found to have been discontinued, leaving a total possible sample of 16 .

The size of the sample limits the ability to use quantitative methods to analyze research findings (Shulman, 1988). Quantitative methods, whether correlational or experimental, require large random samples in order to produce reliable findings. Correlational research, in particular, generally requires the existence of a minimum of thirty cases (Borg \& Gall, 1983). Thus the sample for this study dictated that quantitative methods would have limited effectiveness in this study.

The research questions focused on whether the partnerships in the study were successful and explored the role that some characteristics played in the success of these partnerships. This is what Borg and Gall (1983, p. 354) defined as a "descriptive study" because its purpose is to collect descriptive data that explains "what is" and discovers causal relationships. 
The research strategy used in this study embraced the principle of using different research methods deemed appropriate at different points of the research continuum (Hammersiey, 1992). Quantitative methods were used when summation of data over the 16 partnerships was deemed important. Qualitative methods were utilized because of their recognized ability (Bogdan \& Biklen, 1982) to develop understanding and sensitizing concepts; to arrive at a definition of a situation; to analyze social processes; and to describe the subjective and multiple realities experienced by participants in schools and other educational settings.

Quantitative methods served as a first step in a primarily qualitative study. The quantitative data generated from the surveys consisted primarily of freguenoy distributions which yielded mean scores. This descriptive statistic (the mean) allowed the use of one number to represent the individual scores of the survey respondents. Quantitative methods were used to analyze the survey responses, identify the most successful partnerships, and select the partnerships for the case studies and interviews. In-depth interviews within specific case studies were the primary qualitative methods used in this study because they were most appropriate to the study's objectives of exploring the characteristics thought to contribute to the success of the partnerships. The primary goal of these 
methods is to acquire description from the field in order to better understand the experiences, perceptions, and processes that comprise the reality of the partnerships stuãieà.

The approaches to combining qualitative and quantjtative research advocated by Morgan (1994) were followed in the design of this study. The quantitative data was used as the "preliminary data" because of its ability to provide "input" to the primary methods by quantifying the percejved degree of success of the respondents for comparison and selection. Qualitative methods were selected because they matched the research goals. Case studies and interviews are considered traditional qualitative research methods used to collect in-depth descriptive data (Borg \& Gall, 1983).

\section{Survey.}

The collection of data was conducted in two stages. First, a survey questionnaire was mailed to three key member's of each of the 16 partnerships--all the partnerships that met the aforementioned criteria $(\underline{\mathbb{N}}=48)$. This survey was followed by a case study of two of the partnerships rated as most successful in achieving their perceived goals and objectives. This approach provided broad-based information on current characteristics and practices and an in-depth data on a small number of highly successful partnerships. 
The structured survey questionnaire, composed of forced choice and multiple choice questions, was used to gather a range of general data (Appendix C). The questionnaire was first field-tested with a small sample of respondents. The findings of the field test were used to remove or improve ambiguous questions, and the surveys were then mailed to key informants in the 16 partnerships selected from the available partnership directories and database searches. of the 48 surveys mailed to individuals in the 16 partnerships, 40 were returned for a return rate of $83 \%$. The initial mailings were followed up with telephone reminders 10 days after the initial mailing and periodically thereafter in order to maximize returns.

The remaining 16 partnerships (see Table 1) identified persons from their organizational structure willing and capable of responding to a survey about their partnerships, especially those factors contributing to their success.

The survey was designed to answer the following general research questions:

- To what degree have school/college partnerships that serve minority and disadvantaged students defined, monitored and achieved their goais and objectives?

- Is success measured in any other form? If so how?

- Which objectives do they meet?

The address and phone number of three classifications of survey respondents for each partnership were requested: 
(a) The coordinators or directors of the partnerships, (b) a representative of higher education, and (c) a representative of K-12 schools. Personalized letters were then sent to each of the potential respondents (Appendix D), identifying the name of the contact person at the partnership who had suggested them as a respondent. A survey was mailed to each respondent with the personalized letters, and a code number was placed in the survey to distinguish the respondents. Respondents were requested to reply within two weeks. Twenty surveys were returned within the two-week period. Follow-up phone calls were made every two weeks thereafter to insure the return of the rest of the surveys. Surveys were faxed to those who misplaced them. Data collection continued for two months. Forty-eight surveys were mailed to individuals in the 16 partnerships. Eleven of the 16 partnerships returned all three of the surveys. Three partnerships returned two of the three surveys. One partnership returned one of the three surveys, while another partnership failed to return any of the surveys. In total, 40 of the 48 surveys mailed were returned for a return rate of $83 \%$ (see Table 3).

\section{Case studies}

Case studies of two of the most successful partnerships were conducted to further explore many of the issues identified in the survey. The case studies also focused on the degree to which those partnerships exhibited the 
characteristics of success identified in the literature. Two partnerships, one supported primarily with institutional resources and another funded, with considerable external resources, were selected. The two sites were chosen due to their maximization of success criteria as well as their access to the researcher. The case studies consisted of interviews with collaborative directors and key stakeholders. Ten stakeholders (five from each partnership). were interviewed.

Table 3

Number of Partnership Responses to Survey

\begin{tabular}{|c|c|}
\hline $\begin{array}{c}\text { \# of } \\
\text { Partnerships }\end{array}$ & Respondents to the Survey \\
\hline 11 & Three respondents retumed the survey $(n=33)$ \\
\hline 3 & $\begin{array}{l}\text { Two of three respondents retumed the survey }(n=6 \text { ) } \\
\text { (one partnership selected two persons to respond) }\end{array}$ \\
\hline 1 & One of three respondents returned the gurvey $(n=1)$ \\
\hline 1 & None of the three surveys were returned by one parinership $(n=0)$ \\
\hline & Total surveys retumed: 40 \\
\hline
\end{tabular}

The purpose of the case studies was to discern how two rartnerships differed in their approach and experiences. The interviews of the key stakeholders were open-ended, allowing the informants to speak generally of their 
experiences with the development of the partnership. The interviews were taped and transcribed in a manner that assured the subjects' confidentiality. The interview protocol is F̂ound in Appendix $\mathbf{E}$.

The questions in the interview protocol were organized in part to review the development of the partnerships, beginning with the formative years and progressing through its development. The purpose of the interviews was to elicit the perspective of each respondent in the following areas of partnership development and activities: leadership, partnership goals and management, organizational change, funding, activities leading to student success, college retention, improvement of the image of postsecondary institutions, and partnership formation and development. These areas coincide with those noted in the literature relevant to successful partnerships.

Table 4 describes the interview questions, the rationale for the question, and the location of the discussion of the topic in this study. 
Table 4

Interview Protocol

\begin{tabular}{|c|c|c|}
\hline QUESTION & RA'TIONALE & CHAPTER \\
\hline $\begin{array}{l}\text { 1. Describe the leadership roles in the } \\
\text { formation of the partnership. Who was } \\
\text { involved? What role did the different } \\
\text { people play? }\end{array}$ & $\begin{array}{l}\text { Seeking to identify the most important } \\
\text { influence (persons/institutions) in the } \\
\text { formation stage. }\end{array}$ & Ch 4 \\
\hline $\begin{array}{l}\text { 2. Describe the leadership roles in the } \\
\text { continuing operation of the partnership. } \\
\text { What role do the different people play? } \\
\text { Is commitment to the partnership evident? } \\
\text { In what ways? }\end{array}$ & $\begin{array}{l}\text { Commitment of the top leadership is an } \\
\text { important characteristic of success } \\
\text { identified in the literature. }\end{array}$ & Ch 2 \\
\hline $\begin{array}{l}\text { 3. The survey you completed indicates } \\
\text { that the partnership goals are relatively } \\
\text { clear. In what ways does the partnership } \\
\text { make the goals clear? Does the } \\
\text { partnership use different strategies to } \\
\text { clarify its goals to the different } \\
\text { communities? }\end{array}$ & $\begin{array}{l}\text { Proclamation of clear goals and } \\
\text { declaration of mutual self interest is an } \\
\text { important characteristic of success } \\
\text { identified in the literature. }\end{array}$ & Ch. 2 \\
\hline $\begin{array}{l}\text { 4. How would you describe the manner } \\
\text { in which the partnership makes major } \\
\text { decisions? Can you provide an example? }\end{array}$ & $\begin{array}{l}\text { Shared decision making is an important } \\
\text { characteristic of success identified in the } \\
\text { literature. }\end{array}$ & Ch 2 \\
\hline $\begin{array}{l}\text { 5. Is there other evidence of the success } \\
\text { of the partnership that is not reflected in } \\
\text { existing data? }\end{array}$ & $\begin{array}{l}\text { Seeking other information on success } \\
\text { that was not anticipated in the survey } \\
\text { and may point out important outcomes. }\end{array}$ & Ch 4 \\
\hline $\begin{array}{l}\text { 6. Does the management of the } \\
\text { partnerships include a mechanisms for } \\
\text { sharing information between the } \\
\text { participating institutions? } \\
\text { How is this done? Can you provide } \\
\text { examples? }\end{array}$ & $\begin{array}{l}\text { The sharing of information is an } \\
\text { important characteristic of success } \\
\text { identified in the literature. }\end{array}$ & $\mathrm{Ch} 2$ \\
\hline $\begin{array}{l}\text { 7. What does the partnership see as the } \\
\text { "time frame" for its work? How does } \\
\text { this time perspective play out in its } \\
\text { activities? }\end{array}$ & $\begin{array}{l}\text { Commitment to a long term relationship } \\
\text { is an important characteristic of success } \\
\text { identified in the literature. }\end{array}$ & $\mathrm{Ch} 2$ \\
\hline $\begin{array}{l}\text { 8. Has the partnership affected any } \\
\text { significant institutional change? How do } \\
\text { you define these? How do you know that } \\
\text { these changes have made a difference? }\end{array}$ & $\begin{array}{l}\text { Institutional change and reform was } \\
\text { achieved to some degree or substantially } \\
\text { by both partnerships. }\end{array}$ & $\begin{array}{l}\text { Ch } 4 \\
\text { Appended } \\
\text { table }\end{array}$ \\
\hline
\end{tabular}


Table 4

\section{Interview Protocol (continued)}

\begin{tabular}{|c|c|c|}
\hline RUESTION & RATIONALE & CriAPTEK \\
\hline $\begin{array}{l}\text { 9. Is there evidence of increase in trust } \\
\text { or improved relationship betwcen college } \\
\text { and school staffs? } \\
\text { In what areas were the improvements? }\end{array}$ & $\begin{array}{l}\text { Indicated in survey responses as an area } \\
\text { in which both experienced success. } \\
\text { Developing trust is one of the success } \\
\text { characteristics identified in the literature. }\end{array}$ & $\begin{array}{l}\text { Ch } 4 \\
\text { Appended } \\
\text { chart on the } 2 \\
\text { partnerships } \\
\text { Ch } 2\end{array}$ \\
\hline $\begin{array}{l}\text { 10. How does the staff at the } \\
\text { participating institutions demonstrate } \\
\text { support for the partnership? } \\
\text { What impact does their support have? }\end{array}$ & $\begin{array}{l}\text { Seeking to answer one of the research } \\
\text { questions on the influence of the } \\
\text { partnerships on organizational change. } \\
\text { Promotion of improved relationships } \\
\text { between staffs was identified as an } \\
\text { objective that had been frequently met. }\end{array}$ & $\begin{array}{l}\text { Appended } \\
\text { table on the } 2 \\
\text { partnerships. }\end{array}$ \\
\hline $\begin{array}{l}\text { 11. Tell me how the partnership is } \\
\text { funded. How are decisions made about } \\
\text { the nature and source of funds? Who } \\
\text { makes these decisions? How does the } \\
\text { level, source and continuity of funding } \\
\text { affect the partnership gosls? }\end{array}$ & $\begin{array}{l}\text { Most partnerships expire because of lack } \\
\text { of funding. } \\
\text { Adequate financial support is one of the } \\
\text { characteristics of success identified in } \\
\text { the literature. }\end{array}$ & Ch 2 \\
\hline $\begin{array}{l}\text { 12. Tell me about the "balance" between } \\
\text { the members of the partnership. Who } \\
\text { does what? What process is used to } \\
\text { ensure that cach member contributes } \\
\text { relatively equally to the goals of the } \\
\text { project? }\end{array}$ & $\begin{array}{l}\text { The two case study partnerships have } \\
\text { different funding structures: One is } \\
\text { funded axtensively by several sources, } \\
\text { the other ins been funded primarily by } \\
\text { one source. }\end{array}$ & $\begin{array}{l}\text { Ch } 4 \\
\text { Survey data } \\
\text { appended table }\end{array}$ \\
\hline $\begin{array}{l}\text { 13. Have there been specific actions you } \\
\text { have undertaken that have bean helpful } \\
\text { in: } \\
\text { (a) Academic preparation of high } \\
\text { school students? } \\
\text { (b) Enrollment of minority students in } \\
\text { postsecondary education? }\end{array}$ & $\begin{array}{l}\text { Improved high school preparation was } \\
\text { achieved with apparent high succriss by } \\
\text { both partnerships. } \\
\text { Increased minority higher ed enrollment } \\
\text { was achieved with apparent high success } \\
\text { by both partnerships. }\end{array}$ & $\begin{array}{l}\text { Ch } 4 \\
\text { Appended } \\
\text { table } \\
\text { Ch } 4 \\
\text { Appended } \\
\text { table }\end{array}$ \\
\hline $\begin{array}{l}\text { 14. Tell me the partnerships position on } \\
\text { the retention of minority students in } \\
\text { postsecondary institutions. Is it an issue? } \\
\text { Whose issue? How is it being addressed? }\end{array}$ & $\begin{array}{l}\text { Success throughout the educational } \\
\text { pipeline is one of the perceived goals of } \\
\text { the partnerships. Colleges claim to be } \\
\text { concerned about minority completion } \\
\text { rates. }\end{array}$ & $\begin{array}{l}\text { Ch } 4 \\
\text { Appended } \\
\text { table on the } 2 \\
\text { partnerships }\end{array}$ \\
\hline
\end{tabular}


Table 4

Interview Protocol

(continued)

\begin{tabular}{|l|l|l|}
\hline \multicolumn{1}{|c|}{ QUESTION } & \multicolumn{1}{|c|}{ RATIONALE } & CHAPTER \\
\hline $\begin{array}{l}\text { 15. What evidence exists that the image } \\
\text { of the participating postsecondery } \\
\text { institutions has been improved by the } \\
\text { formation of the partnership? }\end{array}$ & $\begin{array}{l}\text { Improvement in the image and } \\
\text { community relations of the colleges was } \\
\text { achieved with high success by both } \\
\text { partnerships. }\end{array}$ & $\begin{array}{l}\text { Ch } 4 \\
\text { Appended } \\
\text { table }\end{array}$ \\
\hline $\begin{array}{l}\text { 16. Is partnership formation and the } \\
\text { development of collaboratives recognized } \\
\text { and or studied by the partnership? } \\
\text { How is it done? What have you learned? }\end{array}$ & $\begin{array}{l}\text { Receptiveness to the dynamic nature of } \\
\text { partnerships is characteristic of success } \\
\text { identified in the literature. }\end{array}$ & Ch 2 \\
\hline
\end{tabular}

\section{Data Analysis}

In order to analyze the survey questionnaires, a database file was created for each of the returned survey questionnaires with the use of the FileMaker Pro (1992) computer database software. The information on the files was later transferred into the computer statistics software Statview (1988). The statistics software allowed the researcher to obtain frequency distributions of the responses by the survey respondents, group the respondents by their respective partnerships, and average their responses. The general findings allowed the researcher to gain a portrait of the partnerships reported in Chapter IV. The findings were then used to identify the most successful partnerships and select the two case study partnerships. site visits of two to three days were made to the partnerships. Information on the nature and performance of 
the partnerships was collected prior to the interviews, and five key informants from each of the partnerships were interviewed. An interview protocol (Appendix E) was used to guide the interviews. Responses to the interview questions were organized in a grid and analyzed for consistency and dissimilarities.

\section{Interviewees}

Five interviewees were chosen by each site based on their willingness to participate in the one hour interview. They were all members of the policy making board/committee. At least one interviewee in each site was from the $\mathrm{k}-12$ schools, the administration of the partnership or the postsecondary schools and were selected to represent the perspective of their institutional segment.

A timeline for the conduct of this study is shown in Table 5. This table itemizes the processes and timelines. The next chapter presents the findings of the surveys, the case studies and the interviews. It also summarizes those findings. 
Table 5

Timeline for the study

\begin{tabular}{|l|c|}
\hline \multicolumn{1}{|c|}{ Process } & Timeline \\
\hline $\begin{array}{l}\text { Partnerships identified through review of } \\
\text { directories and database searches. }\end{array}$ & November 93 - January 94 \\
\hline $\begin{array}{l}\text { Phone contacts made to seek the names and } \\
\text { addressees of key survey respondents. }\end{array}$ & February 94 \\
\hline Surveys mailed. & March 94 \\
\hline Surveys returned. & April 94 - May 94 \\
\hline $\begin{array}{l}\text { Survey data analyzed and case study partnerships } \\
\text { selected. }\end{array}$ & May 94 - August 94 \\
\hline Interview protocol designed. & August 94 - September 94 \\
\hline Site visits and interviews. & October 94 - November 94 \\
\hline Analysis of interview data and writing. & December 94 - June 95 \\
\hline Dissertation defense. & Jume 95 \\
\hline
\end{tabular}




\section{CHAPTER IV}

RESULTS

Survey Findings

The survey (Appendix C) inquired about a wide range of characteristics and activities of the partnerships such as: organizational structure and leadership, finances, definition of goals, success in achieving goals, factors influential to their formation, extent to which objectives are met, and the data collected to measure success.

The survey inquired first about the "structural characteristics" of the partnerships, i.e., those that describe important elements of the partnerships' structure as an organization, including whether the partnerships are guided by written agreements and policy making bodies, and whether the partnerships have assigned coordinators on a full-time basis. These structural characteristics are crucial to the success of partnerships according to the literature. The following questions were used to explore structural characteristics:

- Is there a written agreement which establishes the partnership?

- Is there a specific person responsible for coordinating the partnership? 
- If yes to the above question, Is this person assigned to work full-tine for the partnership?

- Is there a formal coordinating committee guiding the direction of the parknership?

Frequency distributions were computed for all the responses to help provide descriptive data on the total group. The survey responses were also used to gauge the success of the partnerships in achieving their goals and objectives, group them according to their ability to meet their objectives, and select the most successful for case studies.

Many of the important structural characteristics for success identified in the literature (Chapter II) are present in a high percentage of the partnerships studied. As noted in Table 6, written agreements were present in the partnerships, according to $82 t$ of the respondents. Some $95 \%$ of the partnerships designated an individual to act as a coordinator (approximately half indicated that they have a full-time coordinator), and 77\%, of the partnerships were guided by a committee or board of directors.

The existence of adequate resources is another important feature of successful|partnerships identified in the literature. The lack of resources is frequently the principal reason for the tedmination of partnerships noted earlier which were found to have expired. The survey sought 
to identify the level of annual funding of partnerships by posing the following question:

- What is the total annual operating budget for your partnership?

Table 6

Structural Characteristics of the Partnerships

\begin{tabular}{|l|c|c|c|}
\hline \multicolumn{1}{|c|}{ Characteristics } & Yes & No & $\begin{array}{c}\text { No } \\
\text { Responses }\end{array}$ \\
\hline $\begin{array}{l}\text { Have a Written Agreement } \\
\mathbf{N}=40)\end{array}$ & $\begin{array}{c}82.5 \% \\
(\mathrm{n}=33)\end{array}$ & $\begin{array}{c}17.5 \% \\
(\mathrm{n}=7)\end{array}$ & \\
\hline $\begin{array}{l}\text { A Coordinator is Assigned } \\
\mathbb{N}=40)\end{array}$ & $\begin{array}{c}95 \% \\
(\mathrm{n}=38)\end{array}$ & $\begin{array}{c}5 \% \\
(\mathrm{n}=2)\end{array}$ & \\
\hline $\begin{array}{l}\text { The Coordinator is Employed } \\
\begin{array}{l}\text { Full-Time } \\
\mathbf{N}=37)\end{array}\end{array}$ & $\begin{array}{c}56.7 \% \\
(\mathrm{n}=21)\end{array}$ & $\begin{array}{c}43.2 \% \\
(\mathrm{n}=16)\end{array}$ & 3 \\
\hline $\begin{array}{l}\text { A Committee or Board } \\
\text { Guides the Partnership } \\
(\mathrm{N}=40)\end{array}$ & $\begin{array}{c}77.5 \% \\
(\mathrm{~N}=31)\end{array}$ & $\begin{array}{l}22.5 \% \\
(\mathrm{n}=9)\end{array}$ & \\
\hline
\end{tabular}

Table 7 indicates that a significant percentage of the surveyed partnerships appear to be well funded; budgets of more than $\$ 300,000$ are common in nearly half of the partnerships. There is also diversity of funding levels for the responding partnerships. Nineteen percent of the respondentis indicated that their partnerships operate with budgets of less than $\$ 50,000$, and nearly $29 \%$ believe they are in the middle funding range of $\$ 50,000$ to $\$ 299,000$. 
Table 7

Levels of the Partnerships' Annual Budgets

\begin{tabular}{|c|c|}
\hline Total Annual Operating Budgets & $\begin{array}{c}\text { Rerentinga with Corresponding } \\
\text { Anmual Budgets }\end{array}$ \\
\hline Less than $\$ 50,000$ & $\begin{array}{l}19.3 \% \\
(n=6)\end{array}$ \\
\hline$\$ 50,000$ to $\$ 99,000$ & $\begin{array}{l}9.6 \% \\
(n=3)\end{array}$ \\
\hline$\$ 100,000$ to $\$ 299,000$ & $\begin{array}{l}19.3 \% \\
(n=6)\end{array}$ \\
\hline More than $\$ 300,000$ & $\begin{array}{c}51.6 \% \\
(n=16)\end{array}$ \\
\hline
\end{tabular}

$(\underline{N}=31)$

NOTE: Number of respondents who did not respond to this question: 2.

Whether or not the partnerships had defined, monitored and achieved their goals is one of the central research questions of this study. The responses to the following questions helped give an overview of the perception of partnership success held by the respondents and identify those partnerships that were consistently singled out as successful by the respondents (see questions four through six in Appendix C).

- Does your partnership have formally defined goals?

- Is the achievement of the goals of your partnership monitored?

- Do you consider your partnership to be successful in achieving its goals and objectives? 
- Do you consider your partnership to be successful in achieving its goals and objectives?

Table 8 reveals that a high percentage of these partnerships (more than $80 \%$ ) inaicated that they have defined and monitored their goals, signaling they believe they have a clear sense of direction and some measurable outcomes.

Table 8

Extent to Which Partnerships Define and Monitor their Goals

\begin{tabular}{|l|c|c|c|}
\hline \multicolumn{1}{|c|}{ Questions } & Yes & No & $\begin{array}{c}\text { Non } \\
\text { Respondents }\end{array}$ \\
\hline $\begin{array}{l}\text { Does your partnership have } \\
\text { defined goals? } N=40\end{array}$ & $\begin{array}{c}85 \% \\
(\mathrm{n}=34)\end{array}$ & $\begin{array}{c}15 \% \\
(\mathrm{n}=6)\end{array}$ & $\mathrm{i}$ \\
\hline $\begin{array}{l}\text { Is the schieyement of your } \\
\text { partnership's goals monitored? } \\
\mathrm{N}=39\end{array}$ & $\begin{array}{c}82 \% \\
(\mathrm{n}=32)\end{array}$ & $\begin{array}{c}17.9 \% \\
(\mathrm{n}=7)\end{array}$ & \\
\hline
\end{tabular}

A significant number of respondents considered their partnerships successful in achieving their goals. When asked the question: "Do you consider your partnership successful in achieving its goals and objectives?," all respondents considered their partnership successful in achieving its goals, $35 \%$ considered them somewhat successful, and a significant percentage (64\%) responded that their partnerships were successful in achieving their goals. All together 998 of the respondents believed that 
their partnerships were at least somewhat successful in achieving their goals.

In an effort to assess some of the factors which influenced and motivated the formation of the partnerships studied, the following question was asked (see question 7 in appendix ()) :

- Which of the following do you consider to have influenced the initial formation of your partnership most?

As seen in Table 9, collaboration between institutions and the leadership of one individual are the most influential factors in the formation of the partnexships. A significant number of respondents (41\%) identify the leadership of one individual as being the most influential factor in the formation of their partnership.

Table 9

Factors that Influenced the Initial Formation of the Partnerships

\begin{tabular}{|l|c|c|c|}
\hline \multicolumn{1}{|c|}{ Factors } & Yes & No & No Responses \\
\hline Leadership of One Individual & $\begin{array}{c}41 \% \\
(\mathrm{n}=16)\end{array}$ & $\begin{array}{c}58.9 \% \\
(\mathrm{n}=23)\end{array}$ & 1 \\
\hline Collaboration Between the Institutions & $\begin{array}{c}46 \% \\
(\mathrm{n}=18)\end{array}$ & $\begin{array}{c}53.8 \% \\
(\mathrm{n}=21)\end{array}$ & 1 \\
\hline Community Demand & $\begin{array}{c}12.8 \% \\
(\mathrm{n}=5)\end{array}$ & $\begin{array}{c}87 \% \\
(\mathrm{n}=34)\end{array}$ & 1 \\
\hline
\end{tabular}

$(\underline{N}=39)$ 
Collaboration between institutions was perceived to be the most significant factor by $46 \%$ of the respondents. On the other hand, community demands, cited by only $12.8 \%$ of respondents, appeared to be the least influential factor of the three.

More specific questions were asked in the survey to assess the extent to which the partnerships in the study achieved objectives commonly pursued by school/college partnerships (see question 8 in Appendix C):

- To what extent has each of the following partnership objectives been met?

1. Improving the preparation of minority and disadvantaged high school students?

2. Increasing minority/disadvantage student enrollment in higher education?

3. Improving college student retention rates?

4. Stimulating research?

5. Improving the image and community relations of the colleges?

6. Promoting professional relationships between college and public school staffs?

7. Instituting change or reform?

8. Developing a base for seeking external funds?

As noted in Table 10, the objectives most likely to be achieved "to some degree" or a "substantial degree" are high school preparation, improving the image of the college, 
promoting professional relations between schools and colleges, and institutional change or reform.

Table 10

\section{Estent to wich some of line Parinersinp Objectives Are Met}

\begin{tabular}{|c|c|c|c|c|}
\hline & Not at All & $\begin{array}{l}\text { Some } \\
\text { Degree }\end{array}$ & $\begin{array}{l}\text { Substantial } \\
\text { Degree }\end{array}$ & $\begin{array}{l}\text { Not an } \\
\text { Objective }\end{array}$ \\
\hline $\begin{array}{l}\text { Improve the Preparation of Min } \\
\text { High School Students } \\
(\underline{N}=38)\end{array}$ & $\begin{array}{c}0 \% \\
(n=0)\end{array}$ & $\begin{array}{l}36.8 \% \\
(n=14)\end{array}$ & $\begin{array}{c}60.5 \% \\
(n=23)\end{array}$ & $\begin{array}{c}2.6 \% \\
(n=1)\end{array}$ \\
\hline $\begin{array}{l}\text { Increase Min Higher Ed } \\
\text { enrollment }(\underline{N}=38)\end{array}$ & $\begin{array}{c}0 \% \\
(\mathbf{n}=17)\end{array}$ & $\begin{array}{c}44.7 \% \\
(n=20)\end{array}$ & $\begin{array}{l}52.6 \% \\
(\mathrm{n}=0)\end{array}$ & $\begin{array}{c}2.6 \% \\
(n=1)\end{array}$ \\
\hline $\begin{array}{l}\text { Improve College Retention Rates } \\
(\underline{N}=39)\end{array}$ & $\begin{array}{c}11 \% \\
(n=4)\end{array}$ & $\begin{array}{c}44 \% \\
(n=16)\end{array}$ & $\begin{array}{c}22 \% \\
(\mathrm{n}=8)\end{array}$ & $\begin{array}{c}22 \% \\
(n=8)\end{array}$ \\
\hline $\begin{array}{l}\text { Stimulate Research } \\
(N=39)\end{array}$ & $\begin{array}{c}7.6 \% \\
(n=3)\end{array}$ & $\begin{array}{l}20.5 \% \\
(n=8)\end{array}$ & $\begin{array}{c}23 \% \\
(n=9)\end{array}$ & $\begin{array}{c}48.7 \% \\
(n=19)\end{array}$ \\
\hline $\begin{array}{l}\text { Improve the Image of the } \\
\text { Postsecondary Institutions } \\
(N=39)\end{array}$ & $\begin{array}{c}0 \% \\
(\mathbf{n}=0)\end{array}$ & $\begin{array}{c}25.6 \% \\
(n=10)\end{array}$ & $\begin{array}{c}41 \% \\
(n=16)\end{array}$ & $\begin{array}{c}33.3 \% \\
(n=13)\end{array}$ \\
\hline $\begin{array}{l}\text { Promote Professional Relation } \\
\text { Between Schools/Colleges } \\
(N=39)\end{array}$ & $\begin{array}{c}0 \% \\
(n=0)\end{array}$ & $\begin{array}{c}28.2 \% \\
(\mathrm{n}=11)\end{array}$ & $\begin{array}{c}61.5 \% \\
(n=24)\end{array}$ & $\begin{array}{l}10.2 \% \\
(n=4)\end{array}$ \\
\hline $\begin{array}{l}\text { Institutional Change/Reform } \\
(\mathbf{N}=38)\end{array}$ & $\begin{array}{c}10.5 \% \\
(n=4)\end{array}$ & $\begin{array}{c}55.2 \% \\
(n=21)\end{array}$ & $\begin{array}{c}10.5 \% \\
(n=4)\end{array}$ & $\begin{array}{l}23.6 \% \\
(n=9)\end{array}$ \\
\hline $\begin{array}{l}\text { Base for Seeking Funds } \\
(N=39)\end{array}$ & $\begin{array}{c}0 \% \\
(n=0)\end{array}$ & $\begin{array}{c}41 \% \\
(n=16)\end{array}$ & $\begin{array}{c}38.4 \% \\
(n=15)\end{array}$ & $\begin{array}{l}20.5 \% \\
(n=8)\end{array}$ \\
\hline
\end{tabular}

At the upper end of the scale, some objectives stand out as having been achieved to a substantial degree. The improved preparation of minority high school students has been achieved to be a substantial degree, according to $60 \%$ 
of the respondents, and with some success, according to $36 \%$ of the respondents. Improvement in the professional relations between school and college staffs was promoted to a substantial degree according to $61 \%$ of the respondents. Minority higher education enrollment objectives were met to a substantial degree according to $52 \%$ of respondents and to some degree according to $47 \%$ of the respondents.

By contrast, at the lower end of the scale college retention was deemed to have been achieved substantially by onily $22 \%$ of the respondents, and to some degree, according to $44 \%$ of the respondents. Institutional change and reform were achieved substantially according to only 108 of the respondents, and to some degree according to $55 \%$ of the respondents.

The nature of the data collected to measure success was probed with the following question (see question 9 in Appendix C) :

- What data are collected to measure the success of the students involved in your partnership?

As noted in Table 11, high school graduation rates and college enrollments were the indicators of success most frequently collected in order to gauge success. College preparatory course enrollments, grade point averages, and SAT scores are also frequently utilized to measure success. 
Tabie 11

Data collected by the Partnerships to Measure Success

\begin{tabular}{|c|c|c|c|}
\hline Type of Data Collected & Yes & No & $\begin{array}{l}\text { No } \\
\text { Resp }\end{array}$ \\
\hline $\begin{array}{l}\text { High School Graduation Rates } \\
(\mathbb{N}=33)\end{array}$ & $\begin{array}{c}90.9 \% \\
(n=30)\end{array}$ & $\begin{array}{c}9 \% \\
(n=3)\end{array}$ & 7 \\
\hline $\begin{array}{l}\text { College Preparatory (HS) Course } \\
\text { Enrollments }(\mathbb{N}=33)\end{array}$ & $\begin{array}{l}66.6 \% \\
(n=22)\end{array}$ & $\begin{array}{l}33.3 \% \\
(n=11)\end{array}$ & 7 \\
\hline $\begin{array}{l}\text { SAT Scores (HS) } \\
(\mathbb{N}=32)\end{array}$ & $\begin{array}{c}59.3 \% \\
(n=19)\end{array}$ & $\begin{array}{c}40.6 \% \\
(n=13)\end{array}$ & 8 \\
\hline $\begin{array}{l}\text { Grade Point Average } \\
\mathbb{N}=33)\end{array}$ & $\begin{array}{l}60.6: 8 \\
(\mathrm{n}=20)\end{array}$ & $\begin{array}{c}39.3 \% \\
(n=13)\end{array}$ & 7 \\
\hline $\begin{array}{l}\text { College Enrollment Rates } \\
\mathbb{N}=33)\end{array}$ & $\begin{array}{c}78.7 \% \\
(n=26)\end{array}$ & $\begin{array}{l}21.2 \% \\
(\underline{L}=7)\end{array}$ & 7 \\
\hline $\begin{array}{l}\text { College Graduation Rates } \\
\mathbb{N}=32)\end{array}$ & $\begin{array}{c}46.8 \% \\
(n=15)\end{array}$ & $\begin{array}{l}53.1 \% \\
(n=17)\end{array}$ & 8 \\
\hline $\begin{array}{l}\text { Level of Funding of the Partnerships } \\
\mathbb{N}=32)\end{array}$ & $\begin{array}{c}43.7 \% \\
(n=14)\end{array}$ & $\begin{array}{l}56.2 \% \\
(n=18)\end{array}$ & 8 \\
\hline $\begin{array}{l}\text { Level of Financial Support for the College } \\
\text { Enrollees }(\underline{N}=32 \text { ) }\end{array}$ & $\begin{array}{c}31.2 \% \\
(\mathrm{n}=10)\end{array}$ & $\begin{array}{c}68.7 \% \\
(\mathrm{n}=22)\end{array}$ & 8 \\
\hline
\end{tabular}

College graduation data, however, is collected in considerably fewer cases than is high school graduation data. Only $46 \%$ of the respondents indicated that college graduation data was collected by their partnership 1908 collect high school graduation data). In addition, information on the financial support of the college 
enrollees, potentially a very important determinant of college persistence, was collected by $31 \%$ of the participants; $68 \%$ indicated that they do not collect those data.

\section{Consistency of the Survey}

\section{Responses}

In order to gauge the degree of consistency in the agreement to the survey questions by the respondents, a test of consistency was undertaken. This test used the first six questions on the survey questionnaire because they required "yes" or "no" answers, and lent themselves more readily to that analysis than the remaining questions which offered multiple choices of responses. The responses to the survey from the group of partnerships identified as the most successful (Groun I), were used for this analysis. Thirty-six scores (six questions answered by six partnerships) were attained. The responses to each of those questions were organized into three cells for each of the partnerships. All yes responses to the questions were assigned a number "1," all no responses were assigned a number " 2 ."

The responses were organized into a table (see Table 12) in order to examine the degree of agreement on each of the questions. For example on Question 1 (Existence of a Written Agreement), one respondent from Access 2000 answered with a "2" indicating that there was no written agreement, 
and two of the three respondents answered with a "1" indicating that there was a written agreement for a consistency of $66 \%$ in the responses to that question by the respondents from Access 2000 .

on Question 2 (Coordinator Assigned), the three respondents from Access 2000 answered with a "1" indicating that there was a coordinator assigned for an agreement of $100 \%$ on the responses to that question within that partnership's respondents.

The overall degree of agreement to all six questions by the three respondents from the six partnerships was $90.5 \%$. There was $100 \%$ agreement in the responses to $75 \%$ of the questions (27 of the 36 questions). In the remaining 258 of the questions there was agreement by two of three respondents in $80 \%$ of the questions (7 of 9). The other two questions which reflected $50 \%$ agreement were answered by only two respondents, but those same two respondents had 1008 agreement on the remaining questions. Overall the findings of this test indicate a high level of agreement within each partnership's resporses.

Identifying the Most Successful Partnerships

The main criteria used to identify "successful" partnerships was whether or not the partnerships had defined and achieved their goals. 
Table 12

Consistency of Survey Responses

\begin{tabular}{|c|c|c|c|c|c|c|c|c|c|c|c|c|c|c|c|c|c|c|c|c|c|c|c|c|c|}
\hline & \multicolumn{4}{|c|}{$\begin{array}{c}\text { Uritten } \\
\text { Agreement } \\
01\end{array}$} & \multicolumn{4}{|c|}{$\begin{array}{l}\text { Coordinator } \\
\text { Assigned } \\
02\end{array}$} & \multicolumn{4}{|c|}{$\begin{array}{l}\text { Full-time } \\
\text { Coordinator } \\
\quad 03\end{array}$} & \multicolumn{4}{|c|}{$\begin{array}{c}\text { Guided by } \\
\text { committee } \\
04\end{array}$} & \multicolumn{4}{|c|}{$\begin{array}{c}\text { Goals } \\
\text { Defined } \\
05\end{array}$} & \multicolumn{4}{|c|}{$\begin{array}{l}\text { Goals } \\
\text { Monitored } \\
06\end{array}$} & \multirow[b]{2}{*}{ Total $x$} \\
\hline & $\mathbf{R}$ & $\mathbf{R}$ & R & $x$ & $\mathbf{R}$ & $\mathbf{R}$ & $\mathbf{R}$ & $x$ & $\mathbf{R}$ & x & $\mathbf{R}$ & $x$ & $\mathbf{R}$ & $\mathbf{R}$ & $\mathbf{R}$ & $x$ & $\mathbf{R}$ & $\mathbf{R}$ & $\mathbf{R}$ & $x$ & $\mathbf{R}$ & $\mathbf{R}$ & $\mathbf{R}$ & $x$ & \\
\hline Access 2000 & 2 & 1 & 1 & os & 1 & 1 & 1 & 100 & 1 & 1 & 2 & 66 & 1 & 1 & 1 & 100 & 1 & 1 & 1 & 100 & 1 & 1 & 1 & 100 & 88.6 \\
\hline Fairfax County & 1 & 1 & 1 & 100 & 1 & 1 & 1 & 100 & 1 & 1 & 2 & 66 & 2 & 1 & 2 & 66 & 1 & 1 & 1 & 900 & 1 & 1 & 1 & 100 & 89.6 \\
\hline Project PRIHE & 1 & 1 & 1 & 100 & 1 & 1 & 1 & 100 & 1 & 1 & 1 & 100 & 1 & 1 & 1 & 100 & 1 & $\mathfrak{t}$ & 1 & 100 & 1 & 1 & 1 & 100 & 100 \\
\hline Toledo Compact & 2 & 1 & & 50 & 1 & 2 & & 50 & 2 & & & 100 & 1 & 1 & & 100 & 1 & 1 & & 100 & 1 & 1 & & 100 & 83.3 \\
\hline Sen Antonio Ed & 1 & $i$ & 1 & 100 & 1 & 1 & 1 & 100 & 1 & 1 & 1 & 100 & $\mathfrak{i}$ & 1 & 1 & 100 & 1 & 1 & 1 & 100 & 1 & 1 & 1 & 100 & 100 \\
\hline Bedford Consortium & 2 & 1 & 1 & 66 & 1 & 1 & 1 & 100 & 1 & 2 & 1 & 66 & 2 & 1 & 1 & 66 & 1 & 1 & 1 & 100 & 1 & 1 & 1 & 100 & 83 \\
\hline Question Aversge & & & & 80.3 & & & & 91.6 & & & & 83 & & & & 88.6 & & & & 100 & & & & 100 & 90.5 \\
\hline
\end{tabular}

All partnerships all questions consistency ayerage $=90.5 \%$

Response (R) Coding: $1=$ Yes; $2=$ No 
Three questions were used to assess partnership success: The extent to which the partnerships had defined their goals; whether the goals were monitored; and finally whether goals had been achieved successfully (see questions 4-6 in Appendix C). A scoring system was developed to identify those partnerships indicating high goal achievement. Scoring was determined by assigning points ( 1 to a yes response, 0.5 to a somewhat response, and 0 for a no response) to the three questions that asked whether their goals were defined, monitored and achieved.

The computations show that the respondents from six of the partnerships (Group I) indicated in every response to the three questions that their partnership had defined, monitored and met their goals. That group received the maximum score of nine and the members were classified as Group I partnerships. Another group of partnerships had average scores of six to eight points according the scoring system (Group II partnerships), and a smaller group of three partnerships scored on the average below six (Group III partnerships). These are noted in Table 13 below. The same six partnerships in Group I also scored consistently higher on other important survey questions which explored additional structural characteristics associated with success, such as the presence of a coordinator/director and of a policy committee/board. 
Table 13

Partnership Groups

\begin{tabular}{|c|c|c|}
\hline $\begin{array}{c}\text { Group I } \\
\text { Score: } 9 \text { points }\end{array}$ & $\begin{array}{l}\text { Group II } \\
\text { Score: } 6-8 \text { points }\end{array}$ & $\begin{array}{c}\text { Group III } \\
\text { Score: Below } 6 \text { pts }\end{array}$ \\
\hline $\begin{array}{l}\text { *Access } 2000 \\
\text { *Fairfax County Education } \\
\text { Partnership } \\
\text { *Project PRIME } \\
\text { *The Toledo School College } \\
\text { Compart } \\
\text { *San Antonio Education } \\
\text { Partnership } \\
\text { *The Bedford Consortium for } \\
\text { School Achievement }\end{array}$ & $\begin{array}{l}\text { *Colorado VIP } \\
\text { *Educational Consortium of } \\
\text { Central ILos Angeles } \\
\text { *Minnesota Minority Education } \\
\text { Partnership } \\
\text { *Community Alliance to Support } \\
\text { Education } \\
\text { "Hispanic Student Success } \\
\text { Program } \\
\text { *The Boston Higher Ed compact } \\
\text { *Simmons College School } \\
\text { Consortium }\end{array}$ & $\begin{array}{l}\text { *PACE/UCS Liberty } \\
\text { Partnership } \\
\text { *The Think Tank } \\
\text { *Improving High School } \\
\text { Retention for Minority } \\
\text { Students }\end{array}$ \\
\hline
\end{tabular}

As indicated in Table 14, 948 of the Group I partnerships appointed a coordinator, and $75 \%$ of all those coordinators were appointed full-time. These partnerships were also guided by a coordinating committee or board of directors, as noted by $82.3 \%$ of the respondents from Group I. The other partnerships were significantly less inclined to employ a full-time coordinator.

The funding level of the partnerships in Group I was significantly higher, especially when compared to Group III (see Table 15). Group I had a greater percentage of partnerships funded at the $\$ 300,000$ or above level. 
Table 14

Structural Characteristics of the Partnerships by Groups

\begin{tabular}{|l|c|c|c|}
\hline \multicolumn{1}{|c|}{ Structural Characteristics } & Group I & Group II & Group III \\
\hline Coordinator Appointed & $94 \%(\mathrm{n}=16)$ & $93 \%(\mathrm{n}=15)$ & $100 \%(\underline{n}=6)$ \\
\hline Full-Time Coordinator & $75 \%(\mathrm{n}=12)$ & $40 \%(\mathrm{n}=6)$ & $50 \%(\underline{n}=2)$ \\
\hline $\begin{array}{l}\text { Guided by Coordinating } \\
\text { Committee/Board }\end{array}$ & $82.3 \%(\mathrm{n}=14)$ & $81 \%(\underline{n}=12)$ & $57 \%(\underline{n}=4)$ \\
\hline
\end{tabular}

Table 15

Total Budget of the Partnerships

by Group

\begin{tabular}{|l|c|c|l|}
\hline \multicolumn{1}{|c|}{ Total Budget } & Group I & Group II & Group III \\
\hline Less than $\$ 50,000$ & $28 \%(n=4)$ & $16 \%(n=2)$ & $60 \%(n=3)$ \\
\hline$\$ 50,000-\$ 99,999$ & $7.1 \%(n=1)$ & $16 \%(n=2)$ & $0 \$(n=0)$ \\
\hline$\$ 100,000-\$ 299,000$ & $7.1 \%(n=1)$ & $15 \%(n=2)$ & $40 \%(n=2)$ \\
\hline More than $\$ 300,000$ & $57 \%(n=8)$ & $50 \%(n=6)$ & $0 \%(n=0)$ \\
\hline
\end{tabular}

Responses on the extent to which the partnerships met their objectives were also used to identify the most successful groups of partnerships. The particular objectives addressed by these questions are relevant to the success of partnerships created to improve minority enrollment in postsecondary education and were considered 
very important in identifying successful partnerships. They include improving high school preparation, increasing of minority and disadvantaged higher education enrollments, improving college retention, promoting relations between school and college staffs, improving the image of the colleges, and seeking external funds.

Table 16 illustrates that when asked to indicate the extent to which these objectives had been met to a substantial degree, Group I demonstrated higher achievement in the most crucial areas, including high school preparation, college enrollment and college retention. overall the respondents in Group I indicated that their respective partnerships exhibited all of the structural characteristics associated with successiul partnerships. Group I partnership respondents also indicated that they defined, monitored and achieved their goals to a higher degree than the other partnerships and met specific objectives more frequently than the other two groups. Together these findings on structural characteristics and achievement of goals and objectives presented strong evidence suggesting that the most successful partnerships were in Group I. 
Table 16

Objectives Met to a Substantial Degree by the Partnerships

\begin{tabular}{|c|c|c|c|}
\hline Objectives & $\begin{array}{l}\text { Group I } \\
\mathbb{N}=17)\end{array}$ & $\begin{array}{l}\text { Group II } \\
\mathbb{N}=17)\end{array}$ & $\begin{array}{c}\text { Group } \mathbf{m} \\
\mathbf{N}=\mathbf{0})\end{array}$ \\
\hline $\begin{array}{l}\text { Improve high school preparation of minority and } \\
\text { disadvantaged students }\end{array}$ & $\begin{array}{c}82 \% \\
(n=14)\end{array}$ & $\begin{array}{l}53.3 \% \\
\mathbb{N}=8)\end{array}$ & $\begin{array}{c}50 \% \\
(n=3)\end{array}$ \\
\hline $\begin{array}{l}\text { Increase minority and disadvantaged higher } \\
\text { education enrollments }\end{array}$ & $\begin{array}{c}64 \% \\
(n=11)\end{array}$ & $\begin{array}{c}40 \% \\
(n=6)\end{array}$ & $\begin{array}{c}50 \% \\
(\underline{n}=3)\end{array}$ \\
\hline Improve college student retention & $\begin{array}{l}52.9 \% \\
(n=9)\end{array}$ & $\begin{array}{c}42 \% \\
(n=6)\end{array}$ & $\begin{array}{l}20 \% \\
(n=1)\end{array}$ \\
\hline Stimulate research & $\begin{array}{c}17 \% \\
(n=3)\end{array}$ & $\begin{array}{c}25 \% \\
(n=4)\end{array}$ & $\begin{array}{c}16 \% \\
(n=1)\end{array}$ \\
\hline $\begin{array}{l}\text { Promote relations between school and college } \\
\text { staffs }\end{array}$ & $\begin{array}{l}29 \% \\
(n=5)\end{array}$ & $\begin{array}{l}31.2 \% \\
(n=5)\end{array}$ & $\begin{array}{l}16.6 \% \\
(n=1)\end{array}$ \\
\hline Improve the image of the colleges & $\begin{array}{l}17.6 \% \\
(n=3)\end{array}$ & $\begin{array}{c}25 \% \\
(n=4)\end{array}$ & $\begin{array}{c}50 \% \\
(n=3)\end{array}$ \\
\hline Seek external funds & $\begin{array}{c}47 \% \\
(n=8)\end{array}$ & $\begin{array}{c}50 \% \\
(n=8)\end{array}$ & $\begin{array}{c}0 \% \\
(n=0)\end{array}$ \\
\hline
\end{tabular}

\section{Selecting the case study}

\section{Partnerships}

The use of a case study approach to further explore the research questions of this study was necessary for several reasons. First, the universe of partnerships studied was too small (16 partnerships and 39 respondents) to allow for any statistical manipulation of the findings having 
sufficient validity and reliability. Second, some of the research questions focused on how the partnerships developed and place the characteristics of success identified previously in the literature on the partnerships in the study. Those areas were best addressed by utilizing a qualitative research approach, such as the case study/ interview method selected. Finally, in order to explore all the questions posed by the study, a very large and complex survey questionnaire would have been necessary.

The case studies resulted in a closer examination of the history, characteristics and operating philosophy of the partnerships, allowed the researcher to describe the partnerships in terms of the key factors to their success, and to compare these success factors in the literature to those of the partnerships.

After identifying the most successful partnerships by group, the next task of the study was to select two of the most successful from Group I for case studies. This stage of selection concentrated on further analysis of the six partnerships in Group I. The researcher returned to the responses on the key objectives of school/college partnerships pertaining to high school preparation of students, minority higher education enrollments, institutional change and reform, relations between school 
and college staffs, stimulation of research, college retention rates, availability of external funds, and the image of the colleges. Special attention was given to whether or not these objectives had been achieved to a substantial degree. Tables 17-24 demonstrate the responses of the Group I partnerships with regard to these objectives. The analysis of the responses from the Group I partnerships as demonstrated in Tables 17-24 reveals the following: (a) all respondents from three partnerships indicated that they had achieved one objective to a substantial degree, (b) all the respondents from two partnerships indicated that they had achieved two objectives to a substantial degree, and (c) all the respondents from one partnership indicated that they had achieved three objectives to a substantial degree (see Table 25). It should be noted that one of the partnerships, the Toledo Compact, elected to have two well-informed persons respond to the survey. Thus the total number of all their respondents is two as opposed to three for the other partnerships. 
Table 17

Achievement of objective Improve High School Preparation by Group I Partnerships

\begin{tabular}{|c|c|c|c|c|}
\hline Partnership & Not at All & Some & Substantially & Not an Objective \\
\hline Access 2000 & & 2 & $i$ & \\
\hline Fairfax County & & & 3 & \\
\hline Project PRIME & & & 3 & \\
\hline Toledo Compact & & & 2 & \\
\hline San Antonio Ed Part & & 1 & 2 & \\
\hline Bedford Consortium & & & 3 & \\
\hline
\end{tabular}

Table 18

Achievement of objective Increase Minority Higher Education Enrollment by Group I Partnerships

\begin{tabular}{|c|c|c|c|c|}
\hline Partnership & Not at All & Some & Substantially & Not an Objective \\
\hline Access 2000 & & 2 & 1 & \\
\hline Fairfax County & & & 3 & \\
\hline Project PRIME & & 2 & 1 & \\
\hline Toledo Compact & & 1 & 1 & \\
\hline San Antonio Ed Part & & & 3 & \\
\hline Bedford Consortium & & 1 & 2 & \\
\hline
\end{tabular}


Table 19

Achievement of Objective Improve Minority student College Retention by Group I Partnerships

\begin{tabular}{|l|c|c|c|c|}
\hline Partnership & Not at All & Some & Substantially & Not an Objective \\
\hline Access 2000 & & & & 1 \\
\hline Fairfax County & & 2 & & 1 \\
\hline Project PRIME & & 1 & 1 & 1 \\
\hline Toledo Compact & & 1 & 1 & 1 \\
\hline San Antonio Ed Part & & 1 & & \\
\hline & & & & \\
\hline Bedford Consortium & 1 & 1 & & 1 \\
\hline
\end{tabular}

Table 20

Achievement of Objective stimulate Research by Group I Partnerships

\begin{tabular}{|l|c|c|c|c|}
\hline Partnership & Not at All & Some & Substantially & Not an Objective \\
\hline Access 2000 & & & & 2 \\
\hline Fairfax County & & 1 & & 3 \\
\hline Project PRIME & & & & 2 \\
\hline & & 1 & & 1 \\
\hline Toledo Compact & & & & 1 \\
\hline San Antonio Ed Part & 1 & 1 & & \\
\hline & & & & 1 \\
\hline Bedford Consortium & 2 & 1 & & \\
\hline
\end{tabular}


Table 21

Achievement of Objective Promote Relationship Between the College/Schools staffs by Group I Partnerships

\begin{tabular}{|c|c|c|c|c|}
\hline Partnership & Not at All & Some & Substantially & Not an Objective \\
\hline Access 2000 & & & 2 & 1 \\
\hline Fairfax County & & 1 & 2 & \\
\hline Project PRIME & & 1 & 1 & 1 \\
\hline Toledo Compact & & & 2 & \\
\hline San Antonio Ed Part & & 2 & 1 & \\
\hline Bedford Consortium & & 1 & 2 & \\
\hline
\end{tabular}

Table 22

Achievement of objective Improve Image and Community Relations of the Colleges by Group I Partnerships

\begin{tabular}{|c|c|c|c|c|}
\hline Partnership & Not at All & Some & Substantially & Not an Objective \\
\hline Access 2000 & & & 1 & 2 \\
\hline Fairfax County & & & 1 & 2 \\
\hline Project PRIME & & 1 & 1 & 1 \\
\hline Toledo Compact & & & 2 & \\
\hline San Antonio Ed Part & & 1 & 1 & 1 \\
\hline Bedford Consortium & & & 3 & \\
\hline
\end{tabular}


Table 23

Achievement of Objective Institutional Change and Reform by Group I Partnerships

\begin{tabular}{|l|c|c|c|c|}
\hline Partnership & Not at All & Some & Substantially & Not an Objective \\
\hline Access 2000 & & & 3 & \\
\hline Fairfax County & & 1 & & 2 \\
\hline Project PRIME & & 2 & & 1 \\
\hline Toledo Compact & & 2 & & 1 \\
\hline San Antonio Ed Part & & 2 & & \\
\hline Bedford Consortium & & 2 & 1 & \\
\hline
\end{tabular}

Table 24

Achievement of Objective A Base for seeking External Funds by Group I Partnerships

\begin{tabular}{|l|c|c|c|c|}
\hline Partnership & Not at All & Some & Substantially & Not an Objective \\
\hline Access 2000 & & 1 & 1 & 1 \\
\hline Fairfax County & & 1 & 1 & 1 \\
\hline Project PRIME & & 2 & & 1 \\
\hline Toledo Compact & & 1 & 1 & \\
\hline San Antonio Ed Part & & 1 & 2 & \\
\hline Bedford Consortium & & 2 & 1 & \\
\hline
\end{tabular}


Table 25

Objectives Met to a Substantial Degree by the Group I Partnerships

\begin{tabular}{|l|c|}
\hline \multicolumn{1}{|c|}{ Partnerships } & $\begin{array}{c}\text { Number of objectives which } \\
\text { were substantially achieved }\end{array}$ \\
\hline Access 2000 & 1 \\
\hline Fairfax County & 2 \\
\hline Project PRIME & 1 \\
\hline $\begin{array}{l}\text { The Toledo School College } \\
\text { Compact }\end{array}$ & 3 \\
\hline San Antonio Ed Part & 1 \\
\hline $\begin{array}{l}\text { The Bedford Consortium for } \\
\text { School Achievement }\end{array}$ & 2 \\
\hline
\end{tabular}

The funding level of the partnerships was another factor that contributing to the selection of the Toledo School college compact and the Bedford consortium as the case study partnerships. Both respondents of the Toledo Compact indicated that their funding level was higher than $\$ 300,000$. On the other hand all three of the Bedford Consortium respondents reported that their funding level was below that amount. Both partnerships, however, had indicated they had attained a high level of success. This contrast in funding afforded the study an opportunity to explore the degree to which the level and nature of funding had influenced the operation of these two partnerships. 
The highest numbers of substantially achieved objectives were attained by Fairfax County, the Toledo School College Compact and the Bedford Consortium for School Achievement. The Toledo School college Compact and the Bedford Consortium for School Achievement, in addition to signaling significant achievement of objectives, were located within easier reach for on-site case study. The Fairfax County School College Partnership, another top contender for study, was far too inaccessible to the researcher and therefore was not selected.

\section{Case Study I: The Bedford Consortium for School Achievement, An Overview}

This case study describes the characteristics and development of this partnership including its community, the schools it serves, its operations, its funding, and its outcomes. The results of the interviews with five key informants from the Consortium follow the case study.

\section{The community}

The community of Bedford is the largest city in the county, with a metropolitan area population of 456,000 , 189,500 of whom reside within the city limits and 274,000 in its suburban communities. Eighty-seven percent of the city's residents are White, $5 \%$ are Black, $1 \%$ are Native American, $4 \%$ are Asian Pacific Islander, $3 \%$ are Hispanic, and 18 are from other ethnic backgrounds. 
Bedford can be classified as a "blue collar" town, with many of its residents employed in industrial facilities, the local port, aluminum plants and pulp mills. The city is in a relatively low income area; the average per capita income in the county is $\$ 15,023$, which is approximately $\$ 2,000$ less than the national average. The unemployment rate for the county is $9.1 \%$, almost twice the national average in 1994. Nineteen percent of the population earned college degrees, 278 attended some college, 438 are high school graduates, and $11 \%$ failed to graduate from high school. Of Bedford's 189,500 residents, $17 \%$ live below the poverty 1 ine, and $23 \%$ of children 0-17 years of age lived below the federal poverty line in 1989. Nonwhites are disproportionately poor in this community--though only $14 \%$ of the total population, they nevertheless account for $32 \%$ of the low income population.

The Schools

A total of 31,806 students attend Bedford's 5 high schools, 10 middle schools, 37 elementary schools, 14 alternative programs, and a re-entry program. In addition to the school programs, the Bedford schools have a Family Involvement center that provides parenting workshops and other resources to support parents and encourage them to work with their children.

of the total school district population for the 1994-1995 school year, approximately 198 were African 
American, $13 q$ Asian American, $4 \%$ Hispanic, $2 \%$ Native American and $62 \%$ white. In the 1992-1993 school year 458 of middle school students and $33 \%$ of high school students were eligible for free and reduced lunches. In that same year the dropout rate of Bedford students was $16 \%$, up from $11 \%$ two years before.

A follow-up study of 1993 Bedford high school graduates (of which only $67 \%$ were accounted for) found that $38 \%$ were enrolled in two and four-year postsecondary institutions within the state. The data on the Bedford students who took the Scholastic Aptitude Test (SAT) indicates that 28 of the students who tested were Native American, $18 \%$ were Asian American, $14 \%$ African American, $2 \%$ Hispanic and $60 \%$ White, while 38 were from other racial/ethnic groups.

The Partnership--Historical.

Development

The Bedford Consortium for School Achievement (hereafter called the Consortium) was initiated in the community of Bedford in 1979 to help disadvantaged and minority students "pursue excellence through hard work, self discipline, personal integrity and persistence." It originally developed as a student motivational and selfimprovement program with a focus on "total involvement" by students, parents, teachers, administrators, staff and community. 
The Consortium was initiated as part of a national network of community collaboratives organized by a national civil rights organization. That organization targeted students, especially minority and low income students, who were believed to share some of the responsibility for the apathy, drug abuse, low school performance, violence, lack of motivation to achieve, and teenage pregnancy prevalent in many urban, low income and predominantly minority schools. The organization's message was that while "racial and class barriers were diminishing, student efforts too often were invested in pursuits that ill-prepare them to take advantage of the opportunities before them." In order to better their grades, improve their schools and their lives, students themselves must pursue excellence through hard work, selfdiscipline, personal integrity, and persistence.

As a result of the 1978 visit of the leader of this national organization to the state legislature to promote the creation of such programs, the legislature responded by appropriating $\$ 750,000$ for their implementation throughout the state. The state superintendent of Public Instruction then selected the school districts that were to participate. Eight school districts with high populations of low income and disadvantaged students were earmarked. The Bedford school district was one of those selected and initial funding was received in 1979. 
Goals and Objectives

The overall goal of the collaborative was to motivate students to accept greater responsibility for their own education and to strive toward success at school. The specific goals and objectives were as follows:

Goals:

- Opportunity--for equal and quality education;

- Atmosphexe--conducive for positive learning;

- Motivation--to excel against the odds;

- Responsibility--to accept the challenge of life. objectives:

- To establish a committee of school/community persons to advise and plan school activities, as well as assist in establishing policy and practices in target schools;

- To improve student self esteem; to influence positively student occupational and school aspirations;

- To improve school attendance and decrease school dropout rates;

- To improve academic performance.

The Bedford initiative incorporated many of the programs and concepts that were part of the parent national organization's philosophy, such as essay and oratorical contests, parent student and staff pledges, award ceremonies, exposure to higher education institutions, pageants and student leadership activities. These features 
(with few modifications) were to remain the central activities of the program during its entire existence.

In addition to those activities patterned after the national organization's model, the local consortium incorporated a four-week math and science summer academic program at the local private university in 1990. That program drew a large portion of its students from the Consortium's student population. Although the program was not part and parcel of the Consortium, it worked closely with the Consortium to recruit students. During the first year all students for this program were recruited from Consortium schools. An appealing initiative built into the program provided each student a $\$ 1,000$ credit toward tuition at the university for each summer of participation. In addition, university students from several departments served as tutors to the consortium students, and the university hosted advisory committee meetings and an awards banquet.

A major initiative of the partnership was to enlist the participation of the entire community. Thus, higher education institutions, teachers, parents, local churches, media, business, labor and community organizations were to be involved in a community partnership, with each entity playing a complementary role. Accordingly, the president of the local private university was an early leader working with the school district and seeking the cooperation of 
other community leaders. This individual, once a member of the Board of Directors of a local civil rights organization, was encouraged by the leadership of that organization to motivate the higher education community and his own institution to collaborate with the school district in order to improve the academic performance of minority and disadvantaged students in the Bedford schools.

By the Consortium's final year (1994) more than 3,000 students, 700 parents and 575 staff members from 5 high schools, 6 middle schools, and 12 elementary schools were participants in the partnership. Although the Consortium had operated successfully for 15 years, financial support was terminated in the summer of 1994 because the school district (which had become the primary financial supporter) was unable to continue funding. Despite its long-term history, there was little organized reaction to the termination of the consortium. The local civil rights organization, instrumental in the formation of the partnership, did not expressly oppose its elimination. Some parents and community members who were upset over the termination of the consortium sought an audience with the school superintendent in order to complain about its elimination. The superintendent made arrangements for the concerned individuals to meet with district and program staff, who informed them that lack of funds as a result of budget cuts was the reason for the termination of support 
for the partnership, and that an alternative program called "College Access" was being initiated by the schools and the university. This program is to be funded equally by both institutions for the purpose of facilitating the transition to postsecondary education for all Bedford students. This explanation seemed to appease these parents, and no further opposition was heard.

\section{Governance and Management}

The governance and management functions of the partnership were directed and advisea by two committees: an Advisory Committee and a Community Advisory Committee. The three member Advisory Committee was composed of the project director (who wass appointed by the school district administration), the chair of the Parent Advisory Committee (selected by the director to represent the parents on the advisory committee), and a representative of the local university (appointed by the university president). This committee orchestrated the activities of the partnership and facilitated each partner's input and contributions. Its responsibility was fundamentally within the partnership.

The Community Advisory Committee, which brought together business representatives, church organizations, community based minority organizations, and interested parties, was a large committee with 27 members. This committee of volunteers met monthly to learn about the partnership activities and to coordinate appeals for 
resources and assistance. Its primary responsibility rested with external agencies and communities. Participation in this committee waned over the years and was practically nonexistent during the final year of the partnership operations.

\section{operations}

A series of activities, held at the schools and the postsecondary institutions, were initiated by the partnership. These events were designed to increase the motivation and skills of the participating students. They included: oratorical contests, computer literacy programs, an academic olympics, a radio program hosted by the students, student government, a leadership network, a tutoring program for the participating students, fund raising activities, essay contests, a fair housing poster contest, a summer academic program at the local university, a pageant show, and a yearly awards banquet. These are described in more detail below.

- Academic olympics. Each year students in grades 3-12 were given the opportunity to compece in a two and one-half hour test covering the basic skills of English, math, social studies and science. Five students per grade from each of the consortium schools were selected by the community liaisons and the teacher assistants. The test was graded by the research and evaluation section of the school district. The top 10 scorers in each grade advanced to the finals to 
compete in the oratorical contest. students also attended motivational and enrichment workshops and competed in computer skills during the Academic olympics. In addition to academic awards, a rotating team trophy was awarded to the school with the highest number of points. The challenge of the Academic Olympics was to give as much attention, practice, and reward to academics as schools give to their athletic teams.

- Mini Academic olympics. Held at the County Fair each year, these olympics were open to any student wishing to participate. Over 200 students competed in the last event, and the top 10 students in each grade were awarded t-shirts. The top three in each grade were awarded gifts from local businesses.

- Computer Literacy Program. The purpose of this program was to encourage and develop a basic understanding of computers and their applications. The program was conducted on saturdays (five weeks per session) from October to March of each year at four Consortium elementary schools. Two hundred eighty-nine fifth and six graders attended the basic sessions and 10 attended the advanced sessions the last year it was offered in 1994.

- Oratorical contest. over 325 elementary, middle, and high school students participated in the 1993-1994 competition. Students were judged on originality, organization, knowledge of topic, and skill in making 
examples. Other areas rated were voice, style, pose, posture, and eye contact. The downtown Kiwanis club of Bedford sponsored the competition, while school staff and community members acted as judges for the oratorical contest.

- Essay Contest. The goal of this contest was to foster excellence in writing by encouraging students to write in a clear and concise manner. The contest was also expected to help students learn correct language usage and increase their vocabulary. This contest was open to all students in grades $3-12$ in the district. Topics for the contest were selected by the consortium students. The essays were to be 150 words in length for third and fourth graders; 300 words long for fifth and six graders; and 500700 words for seventh through twelfth grade students. Awards were presented for first, second, and third and honorable mention for each grade level at the annual Awards Banquet. The Essay Contest was sponsored by the regional Kiwanis organization for the last six years.

- Fair Housing Poster Contest. This contest was sponsored yearly by the local housing authority and realtors association to commemorate the anniversary of the civil Rights Act of 1968, which included federal fair housing legislation. Students in third, fourth and fifth grades from five school districts, including Bedford, participated in this competition. A panel of judges selected the best 
entries for display at one of the local shopping malls. The winning posters were selected on originality, visual impact, appeal, lettering, gramnar, spelling of words used and effective presentation of the theme. Prizes were given for first through fifth place at a special awards ceremony hosted by the Mayor and the county Fixecutive.

students who participated in many of these activities, as well as their parents, were required to sign a pledge of commitment to help carry out the goals of the program. Included was a commitment for students to study one to two hours each day without interruptions and to prepare themselves physically and mentally to "face life's challenges." Numerous community organizations assisted and contributed resources to help fund these activities during the 15 years of operation. For exanple, tha local xiwanis sponsored and judged the speaking and essay competitions, and the local community college made its facilities available for meetings provided tutoring for the Consortium's students.

\section{staffing}

staffing for the partnership consisted of a full-time director, four community liaisons, six teacher assistants, and one half-time secretary. The director was the principal administrator of the partnership, serving as spokesperson, producing reports on progress, initiating the various 
programs and activities, participating in budgeting and fund raising, and responsible for the selection of the staff.

Each of the community liaisons operated as a Consortium "contact person" in two secondary schools in the Bedford district. Their responsibilities included the coordination of an after-school study center, organizing Consortium student group meetings, encouraging homework completion, motivating students to study and succeed, maintaining contact with the parents through home and school visits, collecting homework, and facilitating the participation of students in the essay and speaking contests and the rest of the activities of the consortium.

The Teacher Assistants performed the same duties as the Community Liaisons but were employed at two elementary schools. The Teacher Assistants and the community Liaisons were school district employees with expanded roles and compensation. A secretary provided clerical and managerial support on a half-time basis. All staff positions were funded by the school district beginning after the third year of the Consortium's existence.

\section{Evaluation}

Although the consensus of those familiar with the partnership was that it was successful in impacting the participants positively in tangible and intangible ways, those perceptions were largely anecdotal and lacking in 
evidential support. Overall, evaluation received scant attention and resources from the partnership.

The only known formal evaluation of the success of the partnership in achieving its goals was conducted in July of 1980. That research focused on the evaluation of the partnership's previously stated objectives (see Table 26), and was carried out by a district staff person normally assigned to evaluate federal programs. This position was eliminated after 1980 because of a decline in the federal funds available for that purpose; neither the district nor any other member of the partnership made new resources available for evaluation.

It is relevant to explore the difficulties encountered by the consortium in its effort to evaluate academic achievement, the first objective in that study. The 1980 evaluation report specifically addressed whether academic achievement of the consortium participants exceeded that of non-participants. The initial method designed to analyze academic achievement consisted of matching control group students with students enrolled in the consortium. Student:s were matched on the basis of grade, sex, race and most recent test scores. To the extent that it was possible, control group students were to be selected from the same school building as the consortium students. Recent test scores (1980) were to be recorded as students enrolled in the partnership. Post-test scores were to be recorded at a 


\begin{abstract}
later point in the school year, and the average difference scores calculated for both the partnership and the control group students.
\end{abstract}

Table 26

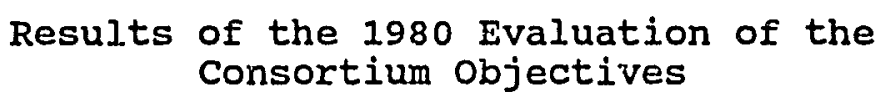

\begin{tabular}{|c|c|c|c|c|}
\hline OBJECTIYES & EXCEEDED & MET & PARTYALLY MET & NOT MET \\
\hline $\begin{array}{l}\text { Academic achievement that exceeded } \\
\text { those of similar students. }\end{array}$ & & & & $\mathbf{X}$ \\
\hline $\begin{array}{l}\text { Reduced rates of absenteeism by the } \\
\text { partnership's participants. }\end{array}$ & & & & $\mathbf{X}$ \\
\hline $\begin{array}{l}\text { Reduced dropout rates and } \\
\text { suspensions. }\end{array}$ & & $\mathrm{X}$ & & \\
\hline $\begin{array}{l}\text { Students demonstrate commitment by } \\
\text { signing pledge. }\end{array}$ & & $\mathbf{X}$ & & \\
\hline $\begin{array}{l}\text { At least } 60 \% \text { of parents will sign } \\
\text { pledge to support students. }\end{array}$ & & & & $\mathbf{X}$ \\
\hline $\begin{array}{l}\text { Community Advisory Committee } \\
\text { established. }\end{array}$ & & $\mathrm{X}$ & & \\
\hline $\begin{array}{l}\text { Building level School Advisory } \\
\text { Committees established with } \\
\text { tepresentation from the Comm Adv } \\
\text { Comnittee. }\end{array}$ & & & $\mathrm{x}$ & \\
\hline $\begin{array}{l}\text { Teachers will demonstrate commitment } \\
\text { by signing pledge in numbers } \\
\text { commensurate with numbers of } \\
\text { students signing in each school. }\end{array}$ & $\mathrm{X}$ & & & \\
\hline $\begin{array}{l}\text { Participating students will fulfill their } \\
\text { contract to do } 100 \text { hours of homework } \\
\text { per semester. }\end{array}$ & & & $\mathbf{X}$ & \\
\hline
\end{tabular}

This approach experienced difficulties, however. For one, more students than anticipated enrolled in consortiumsponsored activities, leaving too few students in the 
control group. In addition, it was not expected that students would continue to enroll in the program over a protracted period. Thus, the problems of low numbers in the control group were exacerbated. Likewise there were limits to the interpretability of the data that were collected. For instance, the population of students included in the partnership group consisted of those students who signed the pledge during the school year. Yet there was significant discrepancy between the number of students who were counted as being included in partnership activities and those who completed the requirements associated with those activities. For example, many who enrolled failed to fulfill their obligation to study the minimum hours as agreed to under the pledge. Thus many students "counted" as partnership participants were members in name only, a factor which minimized the information value of the analysis. For reporting purposes it was concluded that the achievement objective had not been met. But the analysts concluded that. "In truth, we don't know if it has been met or not." A summary of the findings of the 1980 evaluation of objectives is noted in Table 26 .

\section{Funding}

The partnership budget for fiscal year 1993-1994 totaled approximately $\$ 181,000$, with $10 \%$ contributed by the participating colleges and universities, $80 \%$ from the school district, $5 \%$ from foundations and $5 \%$ from business and 
industry. The national organization, which spearheaded the original interest in the partnership, was to provide technical assistance to the Consortium with the support of a federal grant. However, it was never able to assist the Bedford Consortium because the funds designated for the expansion of the consortiums were terminated in 1980 by the federal government. This pattern continued elsewhere as well. Over the course of its 15-year existence, the partnership's financing shifted from state funds to the local school district.

Three years after the initiation of the consortium, the state funds which had been provided by the legislature were discontinued. Yet, the Bedford School District so valued the work of the consortium that it continued to finance it with its own local. school funds. over the years the district redirected some of its Elementary and secondary Education Act Chapter 1 funds to supplement the Consortium's budget. But of late the partnership had received declining amounts of funding from the school district and was finally notified in 1993 that funding would be altogether eliminated.

Interviews with Key Informants

Five key informants were interviewed at length using the interview protocol (Appendix E). They included the former director of the partnership, the chair of the 
Advisory Committee, the representative of the participating local university on the Advisory conmittee, the supervising administrator of the partnership, and a university faculty member of the participating university who has been responsible for the Summer Academic Enrichment Program. The purpose of the interviews was to elicit the perspective of each respondent in the following areas of partnership development and activities: Leadership, goals and management, organizational change, funding, activities leading to student success, college retention, improvement of the image of the postsecondary institutions, importance given to the study of partnership formation and development. The results of these interviews with the Bedford district are noted below.

Question 1: Describe the leadership roles in the formation of the partnership. Who was involved? What role did the different people play?

According to the former partnership director, "The partnership was initiated by the local university president at the urging of the local civil rights organization director." He added that "The school district superintendent was also supportive." The former director recalled that the initial partnership activities were scheduled at the university, and that the university made funding contributions early in the partnership history. The 
program which linked university students to the schools as tutors was also supported by the university.

The school district supervising administrator of the partnership believed that the joint program was initiated by a former Bedford school superintendent but was not sure about the level of involvement of the local university. However, the parent representative to the Advisory Board believed that "the university had more commitment to the partnership, and the university's Dean of Student Affairs was the most influential contributor in the early stages of development."

overall, there were conflicting views and a lack of information on the roles assumed by the leadership of the different institutions in the formative stages of the partnership. Most of the interviewees did not know the role which individuals and institutions played in the formation of the partnership. The responses to the inquiries on leadership during the formation stage were shaped to a significant degree by the length of involvement of the individuals with the partnership. The interviewees were aware of the role played by the leadership only during their tenure with the partnership. Thus, the Director was aware of the level of participation by institutions and individuals during the formative years of the partnership, but that history apparently had not been shared with the recent leadership. 
Question 2: Describe the leadership roles in the continuing operation of the partnership.

According to the former director, the level of support for the partnership had decreased following the departure from the university and the school district of persons who had played key leadership roles in the initiation of the partnership. Since the superintendent who founded the partnership left the district, the district has had two other superintendents. The founding university president retired a few years ago, and the new university president (according to the former director) "does not understand the partnership and is not as excited and committed as the former president."

Most respondents indicated that continuous leadership was in the hands of the partnership director, who was yiewed by the interviewees as the manager of activities, spokesperson, fund-raiser, and motivator of parents, students and staff. The partnership was perceived to be "his program" by the school district and university staffs, according to all the interviewees.

The Advisory Committee was responsible for decisionmaking. The common operating procedure of this committee was to discuss the issues and events on the agenda and make decisions to be carried out by the Director. In the final years of the partnership the large community advisory committee, which had been an active contributor at the 
beginning, essentially disbanded, and the decision-making fell to the Advisory Board.

The university representative on the Advisory Board directed the university's Community service Department. She viewed the partnership as primarily a school district program in which the university was peripherally involved. In her view the summer academic enrichment program and the oratorical contest, both of which were held at the university, were somewhat independent of the partnership in funding and administration, although most of the participants were students from the consortium.

The school district supervising administrator of the partnership perceived the partnership as the project director's program and noted that she was not actively involved in the decision-making process. In the opinion of the supervising administrator, "There was not much coordination between the partnership director and the schools."

The current superintendent has been in bedford for two years and, according to the partnership director, is "familiarizing himself with the district's operation." But according to the administrator who supervised the partnership, the new superintendent was well acquainted with the district and has set broad priorities for parent. involvement, academic achievement and linkages to the 
postsecondary institutions in a comprehensive program that reached beyond the original priorities of the partnership. The partnership was "never defined on paper and the local university was only in a support role," according to the university representative to the Advisory Board. The parent representative to the Advisory Board, on the other hand, believed that the school district's lack of commitment to the partnership was evidenced by its failure to participate and attend the many events organized by the consortium. The partnership director saw himself as primarily responsible for leading the efforts to secure the financial and in-kind contributions of the community organizations that supported the events.

Leadership within the partnership was quite limited and was concentrated within the three-person Advisory Committee. The chief executives of the member institutions were not as involved or linked to the decision-making process as they had been at the beginning of the partnership and were largely ignorant about the partnership's direction and accomplishments. The director, on the other hand, was heavily invested in program operation, which led to a shared perception that the partnership was the director's program rather than a broad based institutional cooperative. Partnership Goals and Management. 
Question 3: In what ways does the partnership make the goals clear? Does the partnership use different strategies to clarify its goals to the different communities?

A series of approaches were used to share the existence, goals and activities of the partnership. There was consensus on the part of the interviewees that the partnership director was the person most actively involved in publicizing the partnership goals and programs. All the interviewees noted that the Director attended numerous meetings of the local service and business organizations in order to drum up support for the activities of the partnership. In some cases he was successful in securing the commitment of these organizations. As an example, the Director arranged for the Kiwanis to sponsor and judge the yearly oratorical competition. The partnership director indicated that he had spoken to every organization in the community at least once in order to raise funds and share information. These requests were influential in procuring much of the local funds for the partnership budget.

Another strategy for the promulgation of project goals was via the media. The partnership published its own newsletter, which was widely distributed to schools, parents and other community members. In addition, the partnership sponsored a monthly half-hour television program which aired on Sunday mornings. This program, hosted by students, 
focused on partnership goals and activities and interviews with special guests.

While other leaders of the partnership participated in these information and public relations campaigns, the director was the most visible advocate. As a forerunner in this area he recounted attending business group meetings and speaking on school matters. And when the school district decided that it was important to communicate with the business community, he was contacted by school officials and asked to share the names of his contacts in the local business organizations. His efforts to discuss the goals, needs and accomplishments of the partnership led him to directly contact community entities with which the schools had previously little communication. "My relations with the business and service organizations in the early years of the partnership were the first efforts by any school district program to reach out to the community beyond the walls of the school," the director pointed out.

Question 4: How would you describe the manner in which the partnership makes major decisions?

According to the director, two committees, created at the inception of the partnership, were designed to facilitate decisions about the direction of the partnership, as well as to seek resources and cooperation from a broad sector of the Bedford community. A Community Advisory Committee (composed of approximately 27 persons representing 
the business community, local churches, utilities, and banks) was active in lseeking resources, cooperation and involvement during the first years of the partnership. The committee was chaired by high profile dignitaries and leaders, including the local NBA (National Basketball Association) basketball coach. However, according to the partnership director, this committee "burned out," and member participation declined over the years. Committee meetings grew increasingly infrequent and were used mostly to share information about partnership activities.

The Advisory Committee was a smaller body composed of the Director, the chair of the Parent Advisory Committee and a representative from the university. This committee was established during the partnership's infancy at the request of the Community Advilsory committee, as a de facto executive commitcee, it made all program decisions and met regularly to share information and discuss future activities.

The parent representative on the Advisory Committee indicated that the decision-making process on the committee was informal. "Issues would be raised and discussed, and a final decision was reached by the committee and implemented by the director," she explained. The university representative and faculty person who were interviewed concurred that partnership activities were patterned after events held in previous years. Major decisions about partnership activities appeared to be predetermined, and 
most advisory committee deliberations were centered around acquisition of resources to implement partnership activities.

As a result of the similarity of the program to previous years, the respondents in general felt that there was little to decide upon. The university faculty member had a "gut feeling" that "the director made all the major decisions." The university representative and the parent representative underscored the opinion that the small advisory committee was the only committee operating and making decisions.

The university representative pointed out that "The Advisory Committee was not a vehicle for telling the director what should be done and how to do it, but rather a vehicle for sharing information," among the committee members and concluded that "This was not a board with authority." Decision-making was open but limited to few participants and did not involve review of major changes in the activities, nor was that process based on any data collection or evaluation. Moreover, decision-making failed to involve those crucial players within the participating institutions, and there is little evidence that a mechanism to keep information about the partnership activities flowing to the participating institutions was in place.

The Community Advisory Committee, which represented a cross-section of community organizations, disbanded in the 
earlier years of the partnership and decision-making was left to the Advisory Committee which operated informally, was lead by the director and concentrated on replicating the traditional activities.

Question 5: Does the management of the partnerships include a mechanism for sharing information between the participating institutions?

The two mechanisms for the dissemination of information to the participating institutions identified by the interviewees were the newsletter and the advisory committee meetings. Newsletters were sent to the school board members and the superintendent and were distributed selectively in the schools. The Advisory Committee meetings were sparsely attended and were not a vehicle for communication between the institutions but rather a forum for updates on activities.

In general, then, information about the activities of the partnership was available through the newsletter; however, meaningful inter-institutional dialogue about the partnership's work was absent. The Advisory Committee meetings were used to discuss such issues as the implementation of upcoming activities and the pursuit of additional resources but fell short of communicating broader aspects of the partnership. The members of the Advisory Committee representing the school district and the 
university did not employ a mechanism for dialogue about the partnership with their institutional colleagues.

Question 6: What does the partnership see as the "time frame" for its work? How does this time perspective play out in its activities?

This partnership was informed in the summer of 1994 that it would cease operations. The school district administrator who was interviewed indicated, however, that while the Consortium would not continue, another organization in cooperation with the university was being established. She explained that "The schools and the local university have created a new vehicle (College Access) which they see as a different structure that will address some of the same needs that the Consortium faced." The parent representative disagreed, however. She believed that "College Access was created to replace the consortium but it is not an adequate replacement because it does not perform the same duties." College Access was designed to promote college enrollment at the local university through college visits but would not continue the oratorical and essay contests nor any of the other activities associated with the consortium.

Question 7: Has the partnership affected any significant institutional change? How do you define these? How do you know that these changes have made a difference? 
A number of changes were identified by the interviewees. According to the partnership director, as a result of the partnership the Bedford public schools "have recognized the positive impact of increasing parent involvement." In his view, the creation of the district's Center for Family Involvement has a direct impact on Consortium activities. This center provided workshops for parents and family members and a library of materials parents could check out. The Bedford schools also adopted a policy expecting parents to volunteer at least 20 hours per year in their child's school.

The university faculty member believed that participation in the partnership not only helped to heighten an awareness by the participating university regarding "the lack of representation of minorities in its student population," it also "exposed the institution to the academic needs of under-represented ethnic minority students." In fact, after the partnership was launched, the faculty member said that some of the university's departments found it easier to initiate programs with individual schools in the Bedford community.

The district administrator pointed to the Bedford schools' continued focus on college preparation/linkage for minority and disadvantaged students, and the initiation of an ongoing relationship with the university in the form of a jointly-funded "College Access" program as evidence of 
institutional change. She indicated that the schools plan to initiate similar relationships with other colleges and universities.

The partnership thus appears to have exemplified and underscored the value of parental involvement, focusing more attention on the role of minority students and developing programs to promote college attendance for minority students.

Question 8: Is there evidence of increase in trust or an improved relationship between college and school staffs? There was consensus among the respondents that although the trust between the schools and the participating university was never low, it has been strengthened through the presence of the partnership.' The university and the schools' representatives pointed out that while their respective institutions have traditionally been involved in other cooperative relationships, the creation of the new College Access program is evidence that a foundation of trust between the university and schools is well established.

Question 9: How do the staff at the participating institutions demonstrate support for the partnership?

The question was not addressed by some respondents because the original partnership|no longer exists. Those who did respond, however, said that neither unqualified support nor antagonism characterized staff activities during 
the years of operation of the partnership. The parent representative who was interviewed believed that the school district administration did not demonstrate sufficient support for the partnership during its existence and was noticeably absent from the partnership activities. She noted that the administrators did not attend partnership activities, and that the school district administration viewed the partnership as the director's program. According to this parent representative, a "personality conflict" existed between the director of the partnership and his immediate supervisors in the school administration. It was her contention that the district administrators did not like the manner in which the director administered the partnership, and that because of their lack of confidence in the director's capabilities the school administrators advocated for the elimination of the partnership.

Although staff members participated in partnership activities whenever the opportunity arose, they did not actively support the partnership. Administrators in the school district were even less supportive and harbored doubts about the partnership's efficiency and success. Question 10: Explain how the partnership is funded. How are decisions made about the nature and source of funds? Who makes these decisions? How do the level, source, and continuity of funding affect the partnership goals? 
For the first three years the partnership was funded entirely with state funds allocated by the legislature for the initiation of eight such entities in the state. At the end of three years, however, state funding was terminated. Thereafter the partnership was supported by funds from the Bedford school district, which believed the partnership to be so siccessful that it funded it with moneys from the local school fund. In subsequent years the school district used federal funds from Chapter 1 of the federal Elementary and secondary Education Act (ESEA) to provide part of the financial support for the consortium. By 1994 the partnership was funded with $\$ 146,000$ of local school funds and $\$ 35,000$ of federal funds from chapter 1 of the ESEA.

In the last few years the school district had been reducing the level of funding of the partnership by $\$ 10,000$ a year. This led the director to seek funds from the private sector in order to supplement the diminishing budget. The partnership had applied for and received scholarship funds from a private foundation, and some of the activities that had previously been supported with school funds were sponsored by private organizations.

"People assumed that this was a wonderful program and the money would be there somehow and would not recognize that the funding level was at peril," noted the university representative. On the other hand, she also felt that it would have been "inappropriate for the university to help 
with additional funding because it was their (the school's) program." Yet the parent representative believed that if the school district had initially financed the partnership from the basic education funds rather than from Federal funds, the partnership would not have had to compete with Special Education and remedial reading programs for limited resources. The school administrator who supervised the parinership indicated she had been concerned that funds were needed to support programs benefiting all children, and that the use of federal ESEA funds should not benefit only the students who participated in the consortium.

Funding from the school district was critical to the success of the partnership. In addition to underwriting the administrative expenses of the partnership, the school funds made it possible to employ the community Liaisons and the Teacher Assistants who composed the staff of the partnership. The reductions in district funds over the last few years undermined the effectiveness of the program. However, it is clear that the partnership was not viewed by everyone as a cost-effective operation worthy of continued Einancial support.

Question 11: Tell me about the "balance" between the members of the partnership. Who does what? What process is used to ensure that each member contributes relatively equally to the goals of the project? 
The university faculty member noted that no written agreement existed to formalize the responsibilities of the partners, she liked the informal nature of the relationship and believed the relationship should remain informal. The "connection between the university and the partnership was informal and that is the way it should be," she noted, adding that the institutions should be responsible for running their own programs and making decisions about them. on the other hand, the school administrator indicated that because the school district funded the partnership, the school district was the primary mover of the partnership. This was borne out by comments of the director, who felt that much of the responsibility for keeping the parinership afloat fell on his shoulders. "I had to beg, borrow and steal to keep it off the ground," he said. The director also noted that the lack of a formal arrangement contributed to the erosion of the commitment of the institutions in the partnership.

Question 12: Is there other evidence of the success of the partnership not reflected in existing data?

There was a widespread perception of the success of the partnership in motivating, promoting, and actualizing academic achievement. Many concurred with one respondent's assessment that "the students benefited emotionally, got involved in their learning, and there was considerable parent involvement." The advisory committee chair explained 
that "the speaking and writing contests, the visits to colleges and universities, the academic olympics and the constant sloganeering and motivational activities of the program developed an identity that bonded and motivated the participants." Another informant added that "Kids learned to speak in public; even autistic children tried and made progress in the oratorical contests."

"If you were to ask the students, as I did, they would tell you that they were glad to participate in all the activities," said one of the university representatives. The school administrator indicated that "students were encouraged to participate in their own learning by designing the topics for the essay and oratorical contests. They responded with insightful suggestions and enthusiasm." These perceptions could not be substantiated with evaluation data other than what was collected in 1980.

Question 13: Have there been specific actions you have undertaken that have been helpful in the following areas:

1. Academic preparation of high school students. The director indicated that students have been helped to set career goals and to take greater responsibility for their own learning while in school. In addition, college visits and SAT preparation workshops seemed to be useful motivators. The parent representative was less positive, indicating she did not believe preparation efforts had been adequate, because the consortium activities did not place 
sufficient emphasis on the development of math related skills. "Last year some work was done to improve math skills, and Geometry was offered to make sure that the Consortium students had the skills necessary to succeed in college." The university representative noted that the partnership's activities have helped to foster student academic preparation, particularly the development of good study habits, public speaking skills, and high expectations.

2. The enrollment of minority students in postsecondary education.

The director noted that student visits to colleges and universities in the region and the annual Black college Fair (held in a city near Bedford) were factors which encouraged students to enroll in postsecondary institutions. The most important activity identified by all respondents, however, was the participation in the summer math and science based program at the locai university. This four-week program for high school students (three weeks for the other students) was especially popular because all students received a $\$ 1,000$ tuition credit at the university for each summer they participated. The provision of a yearly scholarship by the local university to one of the students who participated in the summer program was also universally identified as a college enrollment factor. Overall, however, the specific impact of these activities on academic preparation is unclear since no evaluation of their influence on student 
performance exists. This lack of evidence of success hampered the partnership's ability to demonstrate its overall effectiveness.

Question 14: Tell me the partnership's position on the retention of minority students in postsecondary institutions. Is it an issue? Whose issue? How is it being addressed?

College retention was not one of the stated objectives of this partnership. While it may have been assumed that participation in the partnership activities would increase the academic preparation of its participants, college enrollment and retention were not identified as specific goals of the partnership. The director pointed out that, there was not enough money for that effort. The university representative also had the same perception. The school administrator agreed that there was no involvement in college retention, stating that "The college part was not a priority."

Question 15: What evidence exists that the image of the participating postsecondary institutions has been improved by the formation of the partnership?

The perception of the interviewees is that the image of the university has been improved by the existence of the partnership. "We like to think that the image has improved," said the university representative. She added that the university is gaining a reputation as an 
institution that welcomes minority students: "More minority students attend the local university than before the Consortium began its work." The university representative indicated that people recognize the partnership to be "a good tiring tinat the university has been doing." The school administrator agreed with that assessment. "The local university has had a very good reputation for some time, but by being involved with the partnership it demonstrated interest in student diversity and improved its image in the Bedford community," she said.

Question 16: Is partnership formation and the development of collaboratives recognized and/or studied by the partnership?

Partnership formation and development were not recognized concerns of the partnership. According to one of the university representatives "There is no broad institutional sense that partnership formation is a priority." He believed there is more interest in other issues such as "service learning." The other university representative returned to the theme that the partnership should be operated on an informal basis. "We have a university to run and the school district has its programs to run; we can offer our help and assistance but that is all." speaking about the school district's decision to terminate the partnership in its present form, the same 
person said, "If the school district felt it needed to go in a different direction, who are we to say no?"

The school administrator did not know if the partnership paid much attention to partnership formation and development. She was not close enough to the work of the Consortium to be able to formulate an informed answer but was aware that the school district was preparing a new plan to work with several higher education institutions to create a program of postsecondary preparation and enrollment in which "minority students and all students will be involved." She did not know if this new effort might include an analysis of the principles of partnership formation and development.

\section{Case study II: The Toledo School}

College compact, An Overview

This case study describes the characteristics and development of this partnership including its community, the schools it serves, its operations, its funding, and its outcomes. The results of the interviews with five key informants from the compact follow the case study.

The community

The community of Toledo is located in one of the largest counties in the state (population 2.4 million). Toledo is the largest city in the county with an area of 27 square miles and a population of 295,000 residents. In some 
respects the community of Toledo is an island of minorities in the middle of a non-minority county. Toledo's population consists of 67\% Hispanics, $2.3 \%$ African Americans, 98 Asian and Pacific Islanders, $0.2 \%$ Native American/Eskimos and 23\% Whites. Toledo's unemployment rate is $7.9 \%$--almost twice that of the county--and its median household income is $\$ 35,160$, or about two thirds that of the county. The major industries in the city are electronics, food products, government, medical supplies, retail businesses and computer manufacturing. The county is home to three public colleges (one public research university, one state land grant university and one community college), in addition to one private four-year liberal arts college.

\section{The Schools}

The Toledo School District has a total enrollment of 47,000 students in 43 schools, 28 elementary schools, seven intermediate schools, four high schools, three special schools and one continuation high school. It is a predominantly minority school district with Hispanics constituting $85 \%$ of the population, and Whites, AsianAmericans and African Americans making up the remainder $6 q$, $7 \%$, and $2 \%$ respectively. Consistent with the low per-capita income and high unemployment of the city, a high proportion of school district students (68\%) qualify for free and reduced school meals under the criteria of the U.S. Department of Agriculture for low income families. 
The school district has the largest Limited English Proficiency (LEP) population in the state, with 648 of the students identified as IEP. Within the elementary schools, only $25 \%$ of the students are considered fluent in English. Approximately $40 \%$ of intermediate students and almost $50 \%$ of the students in the high schools are considered fluent in English. This language barrier presents challenges amplified by the fact that many of these students have not been exposed to much formal education in their native country and are not considered literate even in their native language.

The ethnic composition of the school district has changed dramatically during the last decade. In 1982 the district's minority student population stood at $60 \%$, while the figure in 1994 is $94 \%$. Much of this shift can be explained by a large influx of Hispanic (mostly Mexican American) immigrants, which has both increased the minority population even in the presence of a "White, Black, and Asian student flight" from the Toledo district.

As a result of increased immigration on one hand and high dropout rates on the other, the school population is simultaneously expanding and contracting. At Toledo High school, for example, an average of 10 new students enroll each day. Though some high schools report record enrollments, not all students complete the full year and many attend school for brief periods within a year. This is 
reflected in a dropout rate for the Toledo school district of approximately $28 z--$ somewhat higher than the state average of $20 \%$.

Of those students who did graduate in 1990 from Toledo High School, one out of two enrolled in college. Most enrolled in two-year community colleges because only a small fraction (10\%) of the graduates met the admission requirements for the two state university systems.

The Partnership--Historical

Development

The original plan for this partnership emanated from the current director and a staff member of the local research university's Disadvantaged student Services and outreach Program. For two years the project director and others engaged in a series of informal discussions with school district officials, school principals, and faculty in order to explore avenues for improving the level of academic preparation of entering college students. The discussions centered on improving existing school activities, fostering new initiatives and promoting the need for stronger articulation and dialogue between school teachers and university faculties.

The project's first major activity took place in 1983 with a series of dialogues between the university faculty and teachers in the intermediate and secondary schools of the Toledo school district. In order to implement some of 
the ideas generated between the university and the school district, the founders sought the assistance of the Toledo High School principal, who was a self-described "desperate principal in search of funds." This principal was willing to take risks because, in his opinion, the integration of school and university staffs would help raise the selfesteem of teachers and translate into improved teaching skills. These dialogues (or faculty forums) were designed to transmit ideas about new teaching methods and the needs of students; they also were aimed to help dispel the mistrust about the university held by many of the teachers in the school district.

Two forums were held in the spring of 1983 and were supported by a seed grant from the state research university system's President's office. The forum was attended by the school's superintendent, administrators, principals, teachers, counselors, and others. Faculty members from the local research university in such diverse departments as the sciences, mathematics, foreign language, and fine arts also were represented. Promising models for college-based academic preparation programs were presented, followed by discipline-specific discussion groups.

A second forum involving the same participants focused on the development of plans to begin a collaborative effort at each school. The plans included student identification and recognition, objectives for counseling, teacher 
enhancement and recognition, parent and community involvement, university participation, and curricular review activities. As in the first forum, university faculty met with district teachers to follow-up discipline-based exchanges.

The partnership continued to evolve in subsequent years. In 1983 the leadership of the partnership decided to expand the partnership's membership base to include the local public land grant university, the local community college, and the local private liberal arts college. The following year the state established a partnership support program which funded two dozen programs. The mission of this state initiative was "to develop cooperative efforts to improve the academic quality of public secondary schools with the objective of improving the preparation of all students for college." The state allocated a specific grant to the Toledo Compact totaling $\$ 175,00$. It also supported faculty forums, which became important in the implementation of the state's new math curriculum framework and in integrating mathematics and science instruction into the Toledo school district. In 1985 a new superintendent predisposed to collaborative work was selected to lead the school district. The superintendent became the compact co-director along with the project director, who had by then been appointed to a new position as Vice Chancellor for Academic Affairs at the research university. 
From 1987 to 1990 the Compact received additional state funds to operate as a model partnership. It combined the state funds wi.th a three-year $\$ 372,000$ grant from a national foundation to expand its services into the elementary schools. During this period the compact was seen as a "showcase" program for the state and served as a model of a successful mature partnership which had developed comprehensive approaches to curriculum development. The expansion to elementary schools signaled, according to the project's founder, a "conceptual change toward educational restructuring at all levels for all the players." In 1990 the partnership expanded to include another school district in a nearby large urban area. This was a planned expansion that was tied to the third year of funding under a second state partnership grant.

Even though the partnership had achieved significant success, it did not have strong Toledo school board support until 1988 when five new school board members were elected. According to the partnership's associate director, the previous board had been reluctant to recognize the demographic shifts which the district was undergoing since the early 1980 s and to support programs earmarked to serve these students.

Presently the partnership is sustained through two major sources of funds. One is a federally funded grant from the Fund for the Improvement of Post Secondary 
Education (FIPSE). Through this grant the partnership attempts to strengthen teaching relationships between $\mathrm{K}-12$ and postsecondary faculties using discipline dialogues, faculty forums, and faculty teams. The other funding source is a second private foundation grant through which the partnership is seeking to establish regional demonstration schools and teacher training programs to promote minority participation in science and technology. That grant is a three-year commitment and totals $\$ 666,000$.

\section{Goals and objectives}

The compact acts as an administrative framework to secure funding for continuing programs, coordinate potential programs, network compact members, and disseminate information about the partnership. It differs in scale and style from other partnerships in that it focuses on the problems of the school district as a whole rather than selected schools or selected groups of students.

The major goals of the compact are:

- Improve the academic preparation of all students for college, especially underrepresented minority students in mathematics and science;

- Develop future teachers of mathematics and science, especially from underrepresented minority groups;

- Develop a comprehensive model of educational reform, including curriculum review, staff development and student academic preparation; 
- Institutionalize this model by establishing permanent inter-segmental (school/college) partnerships;

- Disseminate this model throughout the educational community.

To accomplish these goals, the Toledo School College Compact organized several specific services, including:

- obtaining funding from a variety of sources to support academic preparation programs in the district;

- Facilitating and maintaining communication among members of the partnership;

- Promoting programs in line with the goals of the district and the compact;

- Publicizing its efforts and successes in order to inform others of the benefits of the collaborative.

\section{Development and operations}

The Toledo School college Compact services are administered by an administrative council, two standing committees and numerous task forces organized by subject area (see Figure 1).

\section{The Administrative Council}

The 37-member Administrative Council is the governing body of the compact, and draws its membership from the five participating institutions: A public research university, a state land grant university, the Toledo school district, a community college, and a private liberal arts college. 


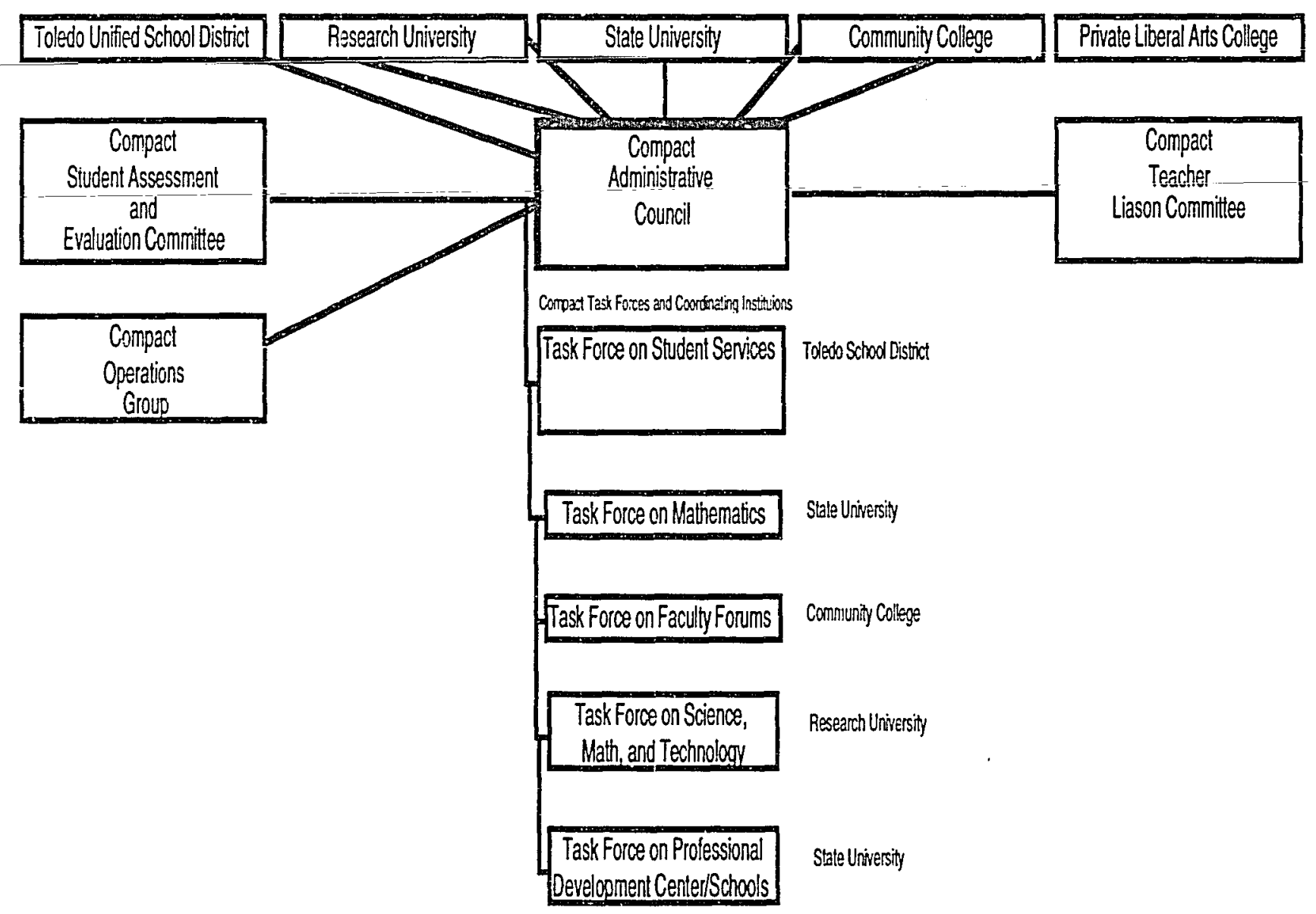

Figure 1. Toledo School college Compact organizational chart. 
Representatives from the postsecondary institutions are appointed by the chief executive officers, while representatives of the Toledo schools are appointed by the superintendent. All members serve a three-year term and elect a Chair and two Vice chairs to lead the council for a one-year term.

The Administrative Council is currently comprised of eight representatives from the community college, eight from the school district, six from the research university, four from the state university and three from the private college. In addition, the council has three representatives from the high schools, three from the elementary schools andtwo from the intermediate schools. Council members are senior staff at their respective institutions and include the district superintendent the assistant superintendents, elementary, intermediate and high school principals, senior postsecondary administrators including deans and university professors, school teachers, and special program administrators from the postsecondary institutions.

Council meetings are held at least four times a year and are hosted by each partner on a rotating basis. Meetings include reports from the project directors, the task forces and the standing committees. During my visit to one of the council meetings, the welcoming and orientation of the new Toledo school superintendent to the compact was the main item on the agenda. In other meetings the 
discussion focused on the difficulties encountered in the state school budget and how it may affect the compact, as well as the status of the Compacts involvement with roledo 2000, the local community improvement plan. Requests for the allocation of funds for new and existing programs are authorized by the Administrative Council, which also serves as a forum in which the educational needs of the schools, potential initiatives and other issues can be discussed. working through their Administrative council, the participating institutions identify district and school needs and coordinate activities to meet those needs. It is perceived as critical to the programs' success that one of the partner institutions assumes responsibility for each project by forming task forces, earmarking resources, and following through on implementation.

A council member may propose a new service (such as a tutoring program) and then work with an existing task force to determine if funding is available. If funds are available and the council approves, a new program will be developed. Another approach is for interested faculty members to seek out funding opportunities tied to a particular service (such as using laser disk technology in the classroom). That faculty member then approaches the council with a proposal to tap this potential source of funding. In both of the above cases, the council can monitor the new programs proposed and evaluate whether they 
meet compact goals. As the council and the task forces develop and implement new and continuing programs, they also distribute information on their activities to other school districts, new faculty members, and to the research community through presentations and publications. The presence of decision-makers on the council signifies each partner's commitment to the project.

\section{Standing Committees}

Two standing committees provide input to the administrative council: The Teacher Liaison committee, and the student Assessment and Evaluation Committee. These committees are chaired by Administrative Council members, but the membership may include council members as well as other individuals concerned about education.

The Teacher Liaison Committee, comprised of 5-10 members, is responsible for selecting a representative of the local teachers' union to the Administrative council. This committee provides a mechanism for communicating concerns from the teachers to the council and vice versa. The student Assessment and Evaluation Committee provides the Compact with assessment instruments and evaluation services. Ten members compose this committee, and the membership usually consists of persons who work in the Institutional Research Departments of the participating institutions.

Task Forces: Each institution on the Council heads at least one task force. Five task forces currently exist: 
Students Services (coordinated by the Toledo school district); Mathematics (coordinated by the state university); Faculty For:ums (coordinated by the community college); Science Math and Technology (coordinated by the state research university); and Professional Development (coordinated by the state university). Task forces are composed of one representative from each postsecondary institution and two representatives from the school district. Members are appointed to serve a one year term. Meetings of the task forces are held at least four times a year and are hosted by the partners on a rotating basis. Task Forces have numerous responsibilities. The Task Force on student services coordinates the programs to improve student preparation for college through outreach, support and services. It also oversees drug education programs and motivates students to stay in school. The Task Force on Mathematics has been instrumental in the restructuring of the district's mathematics curriculum. It also focuses on parental involvement and on students with limited English proficiency. The Task Force on Faculty Forums brings together teachers and faculty from across the educational spectrum--from kindergarten through college--to identify student needs in the district and to aiscuss how to meet those needs. The T'ask: Force on Science, Math and Technology allows university faculty to work with K-12 math and science teachers to integrate technology into their 
lesson plans. The Task Force on Professional Development Center/Schools is designed to train novice teachers and provide continual development for experienced teachers. Four elementary schools, one intermediate school and one high school have been designated as professional development schools. The compact is discussing the establishment of a Professional Development Center that would offer services and resources to all teachers, including in-service and preserve courses on the latest concepts in school reform. The Development Schools would serve as sites where methods would be practiced.

The initiatives of the compact are graphically depicted in the Compact Map (see Table 27). The map lists the activities initiated at five different segmental levels: four-year university, community college, high school, intermediate school and elementary school.

\section{Staffing}

The staffing for the partnership consists of two co-directors and one institutional leader from each of the five partner organizations. Staff members are not directly employed by the partnership but rather by the participating institutions who assign Compact duties to staff members as part of their regular positions. Those co-directors, because they hold prominent positions at their respective institutions, have played an important role in maintaining the direction of the partnership. For example, one of the 
Table 27

The Map of Compact: Associated Initiatives for Local Systemic Reform, 1993-1995

\begin{tabular}{|c|c|c|c|c|c|c|c|}
\hline $\begin{array}{l}\text { EDUCATION } \\
\text {-SYSTENS" } \\
\text { K-16 }\end{array}$ & $\begin{array}{l}\text { I CURRICULUM } \\
\text { ARTICULATION AND } \\
\text { REPORM }\end{array}$ & $\begin{array}{l}\text { II PROFESSIONAL } \\
\text { DEVEOPMENT } \\
\text { PREPARATION }\end{array}$ & $\begin{array}{l}\text { II EVALUATION } \\
\text { ASSESSMENT } \\
\text { PRACTICES }\end{array}$ & $\begin{array}{l}\text { IV STUDENT } \\
\text { ACADEMIC CAREER } \\
\text { GUIDANCE }\end{array}$ & $\begin{array}{l}\text { V STUDENT } \\
\text { LEADERSHIP } \\
\text { ENRICHMENT }\end{array}$ & $\begin{array}{l}\text { VI PARENTS } \\
\text { COMOMUNITY } \\
\text { DEVELOPMENT }\end{array}$ & $\begin{array}{l}\text { VII PROJECT } \\
\text { LEADERSHIP } \\
\text { TEAM } \\
\text { DEVELOPMENT }\end{array}$ \\
\hline $\begin{array}{c}\text { Four-Year } \\
\text { Univenity } \\
\text { Coemminity } \\
\text { College } \\
\text { [13-16] }\end{array}$ & 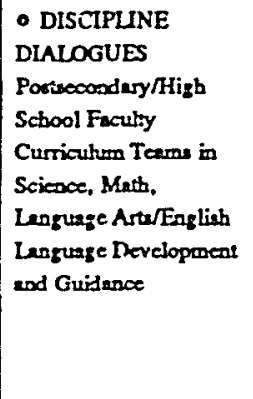 & 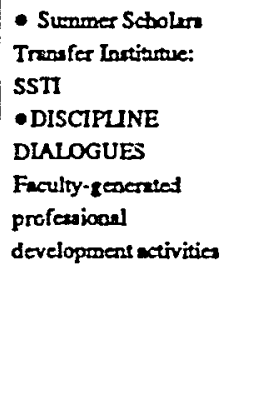 & 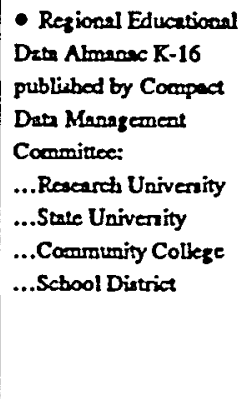 & 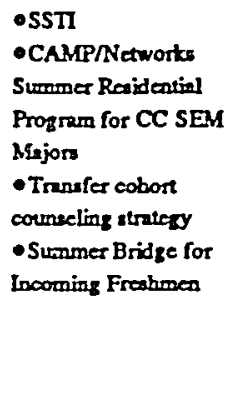 & 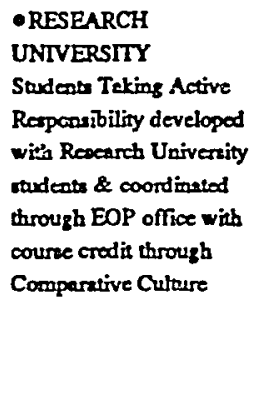 & 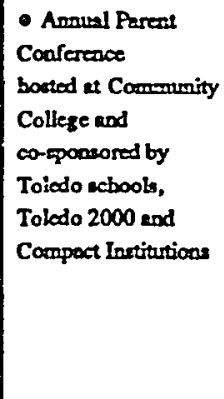 & 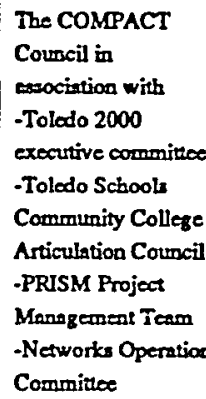 \\
\hline $\begin{array}{l}\text { HIGH } \\
\text { SCHOOL } \\
{[9-12]}\end{array}$ & 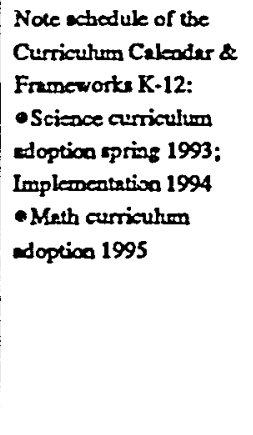 & 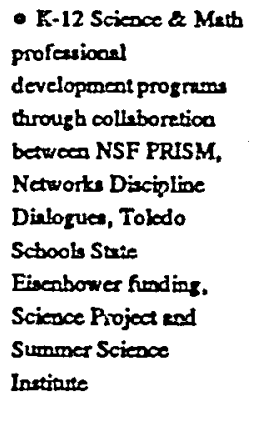 & $\begin{array}{l}\text { - FRISM } \\
\text { Datebere/Stratery } \\
\text { Scrions with cach Higb } \\
\text { School meth \& acience } \\
\text { dopertment } \\
\text { - STUDENT } \\
\text { TRACKING K-16 } \\
\text { with aupport froen } \\
\text { PRISM Detibes: }\end{array}$ & 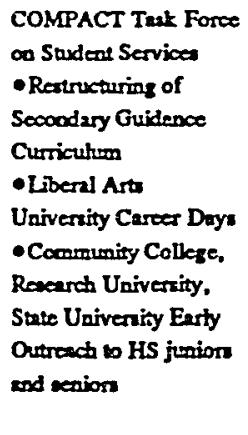 & 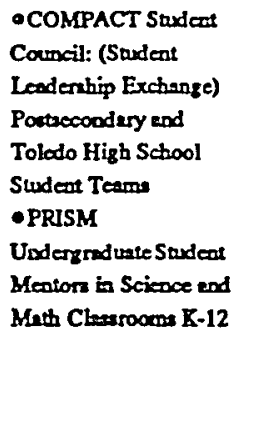 & $\begin{array}{l}\text { - Student end Purent } \\
\text { Guide: Prepering for } \\
\text { Local Collicgea and } \\
\text { Univerritica } \\
\text { - Toledo } 2000 \\
\text { Scholantip Program }\end{array}$ & 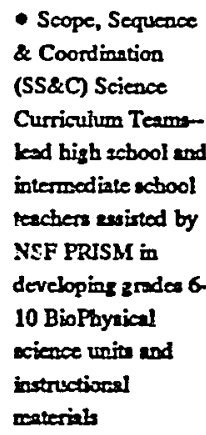 \\
\hline
\end{tabular}


Table 27

The Map of Compact: Associated Initiatives for Local Systemic Reform, 1993-1995 (continued)

\begin{tabular}{|c|c|c|c|c|c|c|c|}
\hline $\begin{array}{l}\text { EDUCATION } \\
\text { "SYSTEMS" } \\
\text { K-16: }\end{array}$ & $\begin{array}{l}\text { I CURRICULUM } \\
\text { ARTICULATION } \\
\text { AND REFORM }\end{array}$ & $\begin{array}{l}\text { II PROFESSIONAL } \\
\text { DEVELOPMENT } \\
\text { PREPARATION }\end{array}$ & $\begin{array}{l}\text { III EVALUATION } \\
\text { ASSESSNENT } \\
\text { PRACTICES }\end{array}$ & $\begin{array}{l}\text { IV STUDENT } \\
\text { ACADEMIC } \\
\text { CAREER } \\
\text { GUIDANCE } \\
\end{array}$ & $\begin{array}{l}\text { V STUDENT } \\
\text { LEADERSHIP } \\
\text { ENRICHIMENT }\end{array}$ & $\begin{array}{l}\text { VI PARENTS } \\
\text { COMMUNTY } \\
\text { DEVELOPMENT }\end{array}$ & $\begin{array}{l}\text { VII PROIECT } \\
\text { LEADERSHIP } \\
\text { TEAM } \\
\text { DEVELOPMENT }\end{array}$ \\
\hline $\begin{array}{l}\text { Interwodiate } \\
\text { School } \\
{[6-8]}\end{array}$ & $\begin{array}{l}\text { c.g., Appliod Math } \\
\text { Articulatica Project } \\
\text { generatod through } \\
\text { Dincipline Dialogues } \\
\text { including CC, HS and } \\
\text { Intermodiate School } \\
\text { faculty (co-fundod by } \\
\text { NSP PRISM and } \\
\text { Networks) }\end{array}$ & $\begin{array}{l}\text { e.g., Math } \\
\text { Reanisaspe Project at } \\
\text { all seven Intermodiate } \\
\text { schools }\end{array}$ & $\begin{array}{l}\text { Grades 6-12 Studeat } \\
\text { Enrollment \& } \\
\text { Performence in } \\
\text { College Prep } \\
\text { Sciesce/Math by } \\
\text { Ethricity }\end{array}$ & $\begin{array}{l}\text { - Projoct SMART } \\
\text { Teacher Track } \\
\text { initiatives to forter } \\
\text { future teachen in } \\
\text { science/math fields }\end{array}$ & $\begin{array}{l}\text { - Youth Alternative } \\
\text { Programs-JTPA and } \\
\text { Youth Alterative } \\
\text { Committoo (YAC) }\end{array}$ & $\begin{array}{l}\text { - Guidance } \\
\text { materials in Spanish } \\
\text { for parents of } \\
\text { intermediate school } \\
\text { etudents }\end{array}$ & $\begin{array}{l}\text { - Nawork } \\
\text { Guidsnce Teams: } \\
\text { Community } \\
\text { College through Gr } \\
8 \\
\text { - Lean piloting } \\
\text { Science \& Math } \\
\text { Core Integrstod } \\
\text { cournea }\end{array}$ \\
\hline $\begin{array}{c}\text { Elemeatary } \\
\text { School } \\
\text { [K-S] }\end{array}$ & $\begin{array}{l}\text {-K-S Adion-banod } \\
\text { Curriculum Reform } \\
\text { Integnting Science, } \\
\text { Miath and Language } \\
\text { Ars }\end{array}$ & 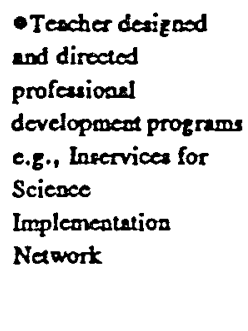 & $\begin{array}{l}\text { - Authentic } \\
\text { Asresement/porfolio } \\
\text { practices } \\
\text { - Coscerns-Besod } \\
\text { Adoption Model }\end{array}$ & $\begin{array}{l}\text { - Puture Scientists } \\
\text { and Engincers of } \\
\text { America clubs } \\
\text { - enginecra team- } \\
\text { teaching at Carver } \\
\text { Elementary }\end{array}$ & $\begin{array}{l}\text { - Research Univeruity } \\
\text { kide end PRISM kids; } \\
\text { Intercession Scieace } \\
\text { Progrem Including } \\
\text { parents end Univerrity } \\
\text { undergraduatea }\end{array}$ & $\begin{array}{l}\text {-Parent Acedeny } \\
\text { for Sciesce/Literacy } \\
\text { at Carver } \\
\text { Elementary } \\
\text { - Kinder Ceminata } \\
\text { bostod at } \\
\text { Community College }\end{array}$ & $\begin{array}{l}\text { - Pemily Math \& } \\
\text { 3cience Teacher } \\
\text { Teams [Bilingual) } \\
\text { - Elemeatary } \\
\text { achool lesd teacher } \\
\text { teamas in State } \\
\text { Univerrity LAMP } \\
\text { projoct: Language } \\
\text { Arts/Mathematics } \\
\text { Integration }\end{array}$ \\
\hline
\end{tabular}


current co-directors is the Toledo school superintendent and the other is the Vice Provost for Academic Affairs at the research university. These individuals help to formulate the long-term goals of the project, gain and maintain consensus among the partners, adjudicate conflicts and serve as promoters for the compact.

An institutional leader is appointed by each partner institution in order to coordinate relations and activities with the compact. These leaders play a vital role in the daily operations of the partnership. Their responsibilities include arranging meetings between partners, writing grant proposals, addressing minor problems or complaints, and directing compact members to the appropriate task forces. While other individuals hold a variety of positions in the partner institutions, all spend approximately one tinird of their time working on the compact activities.

Additional staff are employed to carry out the responsibilities of externally funded grants. Some of these staff members have been retained by the participating institutions at the completion of the grants when the activities become institutionalized within the participating organizations.

\section{Evaluation}

The compact relies on several data sources for general information about the students, teachers, and schools in the Toledo district. Some of the data are compiled according to 
the requirements of the grant funding agencies, other information is made available through statewide data collection efforts, and some data are collected by the institutions specifically for the compact. These data sources include:

- Grant-related data are collected in order to document the impact of the state grant funds to develop school/ college cooperative efforts which improve the academic quality of public secondary schools. Data are collected not only on the number of students involved in the compact activities, but also on the number of teachers and school district staff who participated in faculty forums and other professional development activities.

- statewide data are obtained from the state's basic education data system, which compiles information on schools, teachers and school districts. This data base provides general data on student enrollments, the characteristics of faculty, and various administrative and fiscal data.

- District data include:

1. Transcript analysis: Since 1988, the Toledo school district has analyzed the transcripts of high school seniors to determine their eligibility for entrance to the state's university systems. This information has been valuable in uncovering course deficiencies among high school seniors and proposing corrective measures. 
2. Follow-up survey of high school students: An annual survey of high school graduates has been conducted since 1988. This is a phone survey with a 50 return rate and provides information on employment, training, and schooling. The survey also collects data on student attitudes about their high school experiences.

3. Needs assessment survey of parents: Since 1989, the school district, in conjunction with the state university, has conducted a telephone random sample survey of parents of kindergarten through 12th grade students. Parents are asked about their children's schooling experience as well as their educational aspirations for their children.

4. Descriptive district data are also collected by the Compact staff to track the number of participants and the services provided. They include: numbers of students, faculty and parent participants; trend comparisons of participants from the prior year; numbers of students by grade level and ethnicity; type of curriculum areas covered; and types of activities and services provided.

The descriptive data are used to document and measure progress according to the increase of participants and the addition of curriculum areas.

\section{Funding}

The Compact has no centralized budget, and all support for the operation is provided through in-kind funding in the 
form of salaries paid to the five institutional leaders and the co-director as part of their total salary. The total sum of this in-kind support amounts to $\$ 230,000$. Other sources of partnership funds consist of grants managed by the institutions in order to foster change or to improve delivery systems. These funds are made available by organizations such as the following: The National science Foundation, numerous private national foundations, and the Partnership for Reform in Science and Math. Over one million dollars have been provided by these resources over the life of the compact.

\section{Outcomes}

The objectives of the compact are perceived to have had an impact on the Toledo school district over the past six years. At a general level, participants respond that school and college faculty have worked together to develop and implement a new K-12 math curriculum based on the new state framework. They also note that task forces have monitored current activities and plan needed new initiatives in the areas of math, science, student outreach, drug prevention, self esteem development and faculty forums. Numerous special projects also had come under the Compact's umbrella and are more thoroughly coordinated with existing programs and district goals.

There are also some specific data that suggest success. The district's college-going rate rose from $10 \%$ in 1983 to 
$65 \%$ by 1987 . The results of an annual survey of high school graduates revealed that $72 \%$ of the class of 1989 respondents said they were enrolled in postsecondary education (20\% were enrolled in four-year institutions and $52 \%$ in community colleges). Within the public schools, the percentage of students enrolled in college preparatory courses has increased, as has the number of students who complete four years in the same high school.

Interviews with Key Informants

Five individuals in the Toledo compact were interviewed, following the protocol found in Appendix E. These individuals included the Compact's Associate Director (University's Associate Director of Outreach), a representative of the Toledo school district (Assistant Superintendent), a representative from the community college (Executive Dean of student Services), a representative from the research university (Associate Director of Outreach), and a representative from the state university (Director of Student Academic Services).

Question 1: Describe the leadership roles in the formation of the partnership. Who was involved? What role did the different people play?

The Vice Provost for Academilc Affairs at the participating research universit $\Psi$ and founding co-director of the partnership was accorded most of the credit for the 
initiation of this partnership by all the respondents. In particular, his approach to facilitating dialogues, crafting a power-sharing administrative system, focusing institutional responsibility, raising funds and serving as a national spokesman were significant. The founding co-director was instrumental in "forcing quantifiable power sharing between the institutions," according to the representative of the community college. "He was instrumental in starting the partnership with a couple of grants," alother respondent stated. One of these grants led to the publication of a strategy book on partnership formation, which mapped a blueprint for the structure of the compact. In fact, the book was available in the offices of many of the respondents who were visited by the researcher. According to the compact associate director, institutional commitment to partnership formation preceded the creation of leadership positions filled by the co-director and others. The research university facilitated the notion of partnership formation by creating an Early Outreach Department within the Academic Affairs office, which concerned itself with the preparation of its future university students, especially those underrepresented in its student body. This department was established subsequent to a campus committee having assessed the poor academic preparation of their incoming students. 
The former Toledo school superintendent was also

credited by all the respondents with providing leadership in the early stages of the partnership. As the only CEO who participated personally in the operation of the partnership, shis individual's constant inpuis anc participáiun provided important momentum to the partnership and solidified the commitment of the school district.

Question 2: Describe the leadership roles in the continuing operation of the partnership.

Leadership is presently shared between the co-directors and the middle managers who serve as institutional representatives in the partnership. "A decision was made by the participating CEOs early in the game that middle managers are designated as leaders; it is in their job descriptions," said one of the respondents. He noted that "assistant superintendents, deans and directors of departments are responsible, as part of their jobs, for the partnership activities in their institution."

This approach has made sense to those interviewed. These middle managers have a history of effectiveness in mainstreaming the services and programs of the compact and are able to negotiate change within the culture of their institutions. The fact that middle managers tend to have greatex longevity in their positions is also crucial to the Compact's success. One respondent pointed out that "every one of these institutions has changed CEOs since the compact 
started, and the collaboration persists because it reaches deeper than the top leadership." Middle managers see themselves as being responsible for obtaining CEO cooperation, but they are implementing the long-term institution building which is so necessary for continuity. They direct the work of the task forces assigned to them and help operate the programs for which their institutions receive external funding. Moreover, they represent their respective institutions and are responsible for the sharing of information and the participation of their institutions in the activities of the partnership.

Question 3: In what ways does the partnership make the goals clear? Does the partnership use different strategies to clarify its goals to the different communities?

The partnership associate director noted that partnership goals are defined by the process of reviewing the direction of the partnership and creating compact goals. These goals are jointly developed and discussed in the Administrative Council and reaffirmed through the evaluation of the partnership's accomplishments. Each institution shares the task of clarifying the goals of the programs it administers for the partnership. Publicity about the goals and accomplishments of the various programs is handled by each of the institutions' public relations and public information offices. In addition, Administrative Council members have been active in state and national forums on 
partnership formation, through which they have shared the goals of the compact. The members of the partnership administrative council are also participants in other community-wide improvement and planning efforts. In those capacities the compact members are able to share the goals and activities of their partnership with other key community leaders ،

Question 4:: How would you describe the manner in which the partnership makes major decisions?

Interviewees agreed that decisions are made openly and a process has been designed to bring questions and opportunities to the Administrative Council for final decisions. The compact committed to a decision making process that encourages opportunities for input from all parties. It also relies on information and data to aid in the process. Decisions are made by consensus, but the blessing of the co-chairs is viewed by the interviewees as a valuable reinforcement. These questions, decisions and accompanying proposals may come from the task forces, the staff, or the committees. The allocation and utilization of resources are the usual topics for discussion and decisionmaking.

Question 5: Does the management of the partnership include a mechanism for sharing information between the participating institutions? 
The prevailing opinion is that the partners are "at the table" and well informed about the activities of the partnership. In fact they are all involved in the actualization of the projected activities. Additionally, communication between the faculty and staffs of the schools and the postsecondary institutions has been increased by the faculty dialogues and the network of programs created by the partnership.

The school district representative indicated that one by-product of the partnership has been the creation of a network of coordinated programs that allow for information sharing and increased communication between the school and college faculties. The research university representative commented that school and college faculties work well together because they have established personal relationships through the faculty dialogues.

The Administrative Council is recognized by the respondents as the primary mechanism by which the institutions share information. In addition, the broad participation of institutional representatives in the Administrative Council and the task forces is seen as increasing the opportunities for sharing information with their own institutions.

Question 6: What does the partnership see as the "time frame" for its work? How does this time perspective play out in its activities? 
The associate director stressed that the partnership "will continue until it is no longer needed." The school district representative also believed that the efforts of the partnership will be "ongoing for the foreseeable future with appropriate changes as they become necessary." Continuation and expansion then were important goals in the partnership's foreseeable future, according to the interviewees. For example, replicating the partnership model in a neighboring urban school district is a long-term goal to which the partnership has committed.

In general, the partnership was viewed as a healthy, developing and changing organization. In fact the experiences of the partnership have convinced the participants that they will continue to promote interorganizational collaboration as a necessary philosophical and practical tool to reform and improve educational institutions.

Question 7: Has the partnership affected any significant institutional change? How do you define these changes? How do you know that these changes have made a difference?

All respondents indicated that since its inception, the partnership has sought only those grants or programs specifically designed to enhance the institutions' capacity. This policy has been consciously adhered to by the partnership's administrative council which has, at times, 
rejected grants or programs that were not earmarked for institutional change or improvement. Many of these programs focus on the design of new $\mathrm{k}-12$ curriculum (particularly in the math and science "gatekeeper" courses) or student outreach programs for potential college students. The respondents identified instances in which the administrative council "turned down funds" which were inconsistent with their policy. Adherence to this policy has helped to ensure that the efforts of the partnership are targeted to creating institutional change.

The associate director commented that the schools have "opened up to encourage higher educational institutions to assist in the organization of the $\mathrm{K}-12$ curriculum and involvement in the textbook adoption cycle." The state university representative pointed to increased attention to assisting $\mathrm{K}-12$ teachers as significant to ongoing institutional change. He believed this increased focus was brought about by the university role in teacher inservice training programs made possible by the partnership. Finally, the school district representative responded that the most significant institutional change has been that the partnership has reached beyond the institutional "thinkers" to the institutional "doers," and that partnership's initiatives are now affecting the work of the faculty and staff of the participating institutions. 
Question 8: Is there evidence of increase in trust or an improved relationship between college and school staffs?

All respondents agree that there has been a significant increase in trust between the participating institutions since the inception of the partnership. The associate director recalled that trust between Toledo school teachers and the research university was particularly low prior to the existence of the compact. The discipline-based dialogues and the professional development sessions between school and university faculties have been instrumental in repairing the strained relations between the faculties. Most interviewees cited the willingness of the partners to speak openly about their organizational shortcomings and needs and to entertain suggestions for reform and improvements.

The representative from the state university indicated that institutions share and exchange responsibilities. "One of the institutions may do all the admissions paperwork for the Toledo school district students, while another review all of transcripts. These are functions that we would ordinarily perform separately," he said. The research university representative stated that "There is new communication between the higher education faculty and the faculty of the schools. The 'Discipline Dialogues' opened the lines of communication." He added that "Once we started working with students the focus and commitment changed." 
Participants believed that the schools have benefited extensively from the assistance of the compact in tangible ways, thereby increasing the trust level. As one example, the associate director pointed out that "The teachers have received effective professional development in their own specializations and disciplines, and their entire math and science curriculum was redesigned to meet state requirements, thanks to the compact."

Question 9: How do the staff at the participating institutions demonstrate support for the partnership?

The most palpable manner in which the staff demonstrate support, according to the respondents, is through their participation in the partnership's programs and activities and by their acceptance of the reforms and improvements motivated by the compact. The associate director indicated that "the staff responds to requests for their participation as presenters about the partnerships' activities and are eager to participate even on short notice." The staff of the participating institutions have demonstrated a willingness to cooperate in the pursuit of partnership objectives. They share and exchange responsibilities which the institutions have traditionally performed independently, as they did when the postsecondary institutions in the partnership cooperated in the review of admission applications and transcripts of the Toledo school district students. 
Question 10: Tell me how the partnership is funded. How are decisions made about the nature and source of funds? Who makes these decisions? How do the level, source and continuity of funding affect the partnership goals?

The respondents seem satisfied with the level and the structure of the partnership's funding. Since the core staff (the co-directors, the associate director and the institutional representatives) perform their partnership responsibilities within their extant roles as organizational employees, this arrangement allows/the partnership to function without additional staff resources. All respondents believe that this arrangement solidifies the institutional commitment to the partnership.

other funding for the partnership consists of external funds, referred to by the community college representative as "renewable funds," or those which can be utilized for a specified period of time and are renewable (e.g., federal funds for disadvantaged college students under the TRIO programs portion of the Higher Edudation Act, or chapter 1 funds for $\mathrm{k}-12$ schools). The partnership has worked diligently to obtain these funds for institutional use. Additional funds sought by the partnership are what the community college representative calls "funds for institutional adaptation." These are funds which "can be used to adapt the system to change and which are used to create desired changes." According to the Toledo school 
representative, these funds have enhanced the effectiveness of the partnership and have helped the partners to focus on needs, conduct faculty dialogues, improve services, develop new curriculum and evaluate progress.

The type of funding which the partnership accepts is consistent with its goal of creating and expanding institutional capacity rather than encouraging what they call "fly by night" programs that leave little impact on the institutions. The decision to finance the leadership of the partnership from institutional funds has guaranteed longterm leadership that is committed to partnership formation and maintenance.

Question 11: Tell me about the "balance" between the members of the partnership. Who does what? What process is used to ensure that each member contributes relatively equally to the goals of the project?

While overall there is consensus that an appropriate balance exists between the members of the partnership, it is clear that this was not always the case. "At the beginning, the research university was suspected of trying to grab the spotlight, but those suspicions were later eliminated by their behavior," the state university representative observed. Equal representation on the administrative council, the sharing of responsibility for program implementation, and the shared budgetary support for the institutional leaders have eliminated the concerns about 
balance between the members. The respondents believed that the consensus approach to decision making has also made it easy for each partner to review and object to decisions. According to the associate director, the current management strategy is for each institution to "lead with its strengths" and assume responsibility for areas in which they are considered to have expertise, resources, or experience. Examples of this strategy include the shift of tutorial programs to the community college; the research university is developing a curriculum theme called "writing and Critical Thinking," while the state university is developing a course on "Reading and Critical Thinking," and the school district is sponsoring the series of Faculty Forums.

Overall, there appears to be no discernible conflict with regard to the balance of roles between the partners. In fact, a climate of collaboration seems to encourage solutions. In cases in which questions arise about institutional responsibilities or competition, the co-directors negotiate agreements and attempt to arrive at compromises.

Question 12: Is there other evidence of the success of the partnership that is not reflected in existing data?

The respondents provided some examples of the success of the partnership that may not be reflected by the existing data. One such example cited by the university 
representative was that the staff at the different institutions "work together because they have had common experiences while participating in Compact faculty dialogues which brought them together to discuss intellectual issues." The same individual stated that, while there are no data to support the perception that CEO leadership has made a difference in Compact success, the fact that the cEOs have been committed has led to the conclusion that "the people involved have made the difference."

Respondents provided additional examples. The school district respondent believes that the partnership has coordinated the delivery of services to the school district in a manner that does not interfere with the operation of the K-12 schools. He noted that "The postsecondary institutions have eliminated duplication of services and have established good communication with the schools to arrange for timely delivery of services." The state university representative pointed to the positive experience for community college transfer students designed to familiarize them with the university environment initiated by the state university. Part of that experience includes enrollment in a 10-day university course, which facilitated transfers between community colleges and the universities. Finally, according to the associate director, other evidence of success not reflected in the existing data are the inclusion of partnership responsibilities in the job 
description of institutional representatives, the restructuring of the math curriculum, and indicators that. high school student aspirations for college have been increased, and more than double the number of minority students in the school district express a desire to become teachers.

Question 13: Have there been specific actions which you have undertaken that have been helpful in the following areas?

1. Academic preparation of high school students. When asked this question, the representative from the state university expressed, "That's all we've been doing-reforming curriculum, testing, taking tours and training counselors." The associate director continued saying that she felt it was impossible to separate institutional reforms from the improvement of student preparation. She identified the following institutional actions as significant in the improvement and the preparation of high school students:

- Curriculum reform in math and science.

- The requirement that all ninth graders take Algebra.

- Improved access and retention in the entry-level math and science courses.

- Professional development for K-12 teachers and staff.

- Improved data based on results and achievement. The school district representative said that by using data on student performance he was able to approach school 
administrators and discuss accomplishments and needs. He indicated that he used data about performance to challenge people to change. "I take it to teachers to discuss where the needs exist and what to do for improvements." Moreover, he explained, data currently exists regarding the distribution of grades for students in the high school classes. When high percentages of students receive failing grades in specific courses, the administrators can inquire into the reasons and design a strategy to elevate student performance in these classes. The community college representative felt that the analysis of student failuxe in high school has been a valuable process in identifying problem areas that need to be addressed. For example, the information generated by the compact on the number of students who fail to enroll or complete the traditional college "gatekeeper" courses in math and science was particularly useful in identifying needs in the areas of academic advising, course scheduling, and tutoring.

2. The enrollment of minority students in postsecondary education.

The postsecondary institutions in the Compact have agreed to cooperate in the orientation of potential college students from the Toledo schools. They have coordinated and combined their college recruitment tours and their financial aid application workshops and have agreed to cooperate in assisting students to prepare for college enrollment as a 
group and not to compete for students until the spring of each academic year, when students make their choices about the postsecondary institutions they will attend. Equally important, the compact has initiated a college articulation program between the community college and the universities, aided by funding obtained by the compact from a national foundation.

Question 14: Tell me the partnership's position on the retention of minority students in postsecondary institutions. Is it an issue? Whose issue? How is it being addressed?

This appears to be an emerging critical area. college retention had been accorded lower priority by the partnership, but the associate director indicated that the partnership has received a new foundation grant which will allow it to focus greater attention on college retention. As a result of these funds, a grade 12-16 evaluation plan will be designed and implemented with the involvement of the community college and the universities. This plan will emphasize articulation between the community college and the universities.

The research university representative expressed concern over the lack of attention given to college retention and graduation and saw this as a bottom-line issue for the partnership. He believes that outcome measures on 
college and high school graduation are important if retention is to be taken seriously.

Question 15: What evidence exists that the image of the participating postsecondary institutions has been improved by the formation of the partnership?

The school district representative indicated that he was unaware of whether or not the image of the postsecondary institutions had been improved as a result of the partnership, as he had not been involved in efforts to publicize the partnership. All other interviewees indicated they believed the community recognizes that the postsecondary institutions are helping the schools, and their image has been enhanced as a result. The associate director added that the promotion of the co-director to a vice provost position was interpreted as recognition by the university that his efforts had bolstered the compact's image in the community. She also noted that prior to the existence of the compact, teachers in the school district often were mistrustful of the university, but since the initiation of the dialogues between $\mathrm{K}-12$ and postsecondary faculties, confidence and trust have increased (see Question 8).

Question 16: Is partnership formation and the development of collaboratives recognized and/or studied by the partnership? 
The respondents indicated an understanding of partnership formation and the dynamics involved in such an enterprise. The school representative stated, "I have become a much more collaborative person as a result of participating in this partnership. It has shown us that we can translate ideas and dreams into reality if we learn how to collaborate." The associate director indicated that through the process of sharing information about their model--which is one of the goals of the partnership-participants have been able to analyze their work both from a philosophical as well as practical perspective. She noted that this partnership has consistently examined the phenomena of partnership development. The fact that the current compact design was based upon a lengthy partnership development effort which was successful enough to result in the publication of a handbook on partnership development was seen as a testimony to that process.

\section{Summary}

The following section summarizes and highlights the survey and interview findings.

\section{The survey}

The review of the survey data presents an overall picture of important characteristics of this unique group of school/college partnerships whose goal it is to prepare minority and disadvantaged students for academic success in 
schools and colleges. A significant degree of "commonalty" is found in the responses to the characteristics of each respondent's respective partnership in important areas such as organizational structure, funding, achievement of goals, formative influences, and data collected.

1. Organizational structure: Significant numbers of the respondents $(82 \%)$ indicated that their partnerships had formalized the relationship between the partners with written agreements. The respondents also indicated (95\%) that the partnerships had designated a coordinator to guide partnership activities. In $55 \%$ of the cases that individual was full-time in that position. Seventy-seven percent also indicated that most partnerships were guided by a committee or board.

2. Funding: The funding level of the partnerships varied. Whereas $19 \%$ of the respondents reported that their partnership had less than $\$ 50,000$ in their annual budget, roughly half (51\%) of the respondents indicated that their partnership was funded at more than $\$ 300,000$ annually.

3. Achievement of goals: More than $80 \%$ of the respondents indicated that their partnership defined and monitored their goals. A significant number of partnerships respondents $(64 \%)$ claimed that the partnerships were successful in achieving their goals, while $35 \%$ of the respondents indicated they consider their partnerships at least "somewhat successful" in attaining their objectives. 
Some objectives were said to have been achieved to a substantial degree: The improved preparation of minority high school students had been achieved to a substantial degree, according to $60 \%$ of the respondents and with some success according to $36 \%$ of the respondents. Increases in the college enrollment of minority students have been achieved to substantial according to $52 \%$ of respondents and with some degree of success as reported by $44 \%$ of the respondents. Although increases in the college enrollment of minority students was perceived to have been widespread, college retention of those students fell short of goals, as only $22 \%$ of respondents reported retention had been achieved "substantially."

Institutional change and reform were achieved to a significant degree according to $10 \%$ of respondents and "achieved to some degree" according to a majority of the respondents (55\%). Twenty-three percent, however, indicated it was not an objective.

4. Formative influences: The leadership of one individual (according to 418 of respondents) and collaboration between institutions ( $46 \%$ of responses) were the most influential factors in the formation of the partnerships. Twelve percent identified community demand as the most significant factor in the formation of their partnerships. 
5. Collection of data: Large percentages of respondents $(90 \%)$ indicated that data are collected on high school graduation rates and college enrollment rates (78\%) and that these are some of the indicators most frequently compiled to measure success. other data collected with high frequency included college preparatory course enrollment (66\% of respondents); grade point average (60\% of respondents); and SAT scores (59\% of respondents). College graduation data, however, were collected in considerably fewer cases than were high school graduation data; only $46 \%$ of the respondents indicated that college graduation data were collected by their partnership, compared to $90 \%$ who said they collect high school graduation data. Information on the financial support of the college enrollees (potentially a very important determinant of college persistence) was gathered according to only 318 of the participants, while 68\% indicated that their partnerships did not collect that data.

\section{The Interviews}

This summary of the interviews pays particular attention to the similarities and differences found in the responses to the 16 interview questions. They are reorganized into groups: leadership, goals and management, mechanisms for sharing information, organizational change, improved relations between college and school staffs, funding, balance between the members of the partnership, 
student success, college retention, and partnership development.

Leadership. There were significant differences in the responses to this question from the two groups of interviewees. Bedford Consortium members demonstrated varying levels of knowledge and insight regarding the historical antecedents and the degree of commitment of the different institutions and organizations to the partnership. Their length of involvement in the Consortium seemed to be one influence on the familiarity of respondents with the Consortium's history. For example the director, who was present since the inception of the consortium 14 years ago, had considerable knowledge of the history of the partnership. On the other hand, the university faculty member, who had only been involved for the past four years, had much less awareness about the contributions of individuals to the partnership in the formative stages. On the other hand, the respondents from the Toledo School College Compact shared an in depth awareness of the partnership's history. They were knowledgeable about the developing stages of the partnership and consistently identified the co-director as the person responsible for much of the partnership's early success.

Both partnerships were propelled initially by significant executive commitment and leadership within the member organizations. The Consortium, however, soon lost 
its CEO executive involvement. Since the founding college president and superintendent retired or moved to other positions, subsequent university presidents and school superintendents became increasingly detached from the partnership. But the Toledo Compact consistently recruited its executive leadership from persons within member organizations. These middle managers helped to provide security within the changing nature of member organizations. The leadership role in the consortium was initially undertaken by a large Community Advisory Board which provided support and direction to the partnership. over the years, participation on this board declined, creating frustration and "burn out" for those remaining. When the Board ceased its operations in 1986, decision-making then transferred to a three-member advisory committee which was considerably less influential because it did not include high level administrators from any of the participating institutions. In addition, the university's commitment to the Consortium changed significantly following the retirement of the consortium's founding president. The most recent university representative on the consortium's Advisory Committee, however, minimized her personal involvement in the leadership of the partnership. She made it clear that neither she nor the university was involved with the partnership and insisted the partnership was a 
school district program in which the university was only peripherally involved.

The compact, by comparison, was directed by a large Council (39 members) composed of the CEOs and sizable numbers (6-8) of middle managers from all the partner institutions. Leadership and service to the compact were provided by the managers and officials of the compact as part of their work responsibilities. Delegating leadership responsibilities within the partnership was consistently followed by the compact to ensure shared ownership and enhance the possibilities of organizational change. These strategies were developed and followed by the founding codirector, whose leadership served as the glue which held the Compact partnership together. He was consistently nominated by interviewees for his understanding of organizational dynamics and his commitment to organizational improvement. Goals and management. The two partnerships used different vehicles to share and clarify their goals. The Consortium relied on personal appearances at civic, business, social service, and religious organizations. often these visits were planned in order to share information on the consortium's activities and to seek support for its programs. The director of the Consortium was most frequently the person in charge of publicizing programs and goals, and he visited many of the business organizations and churches in the community for that 
purpose. The compact, on the other hand, handled publicity and information on its programs through its respective inhouse public relations and publicity mechanisms, thereby allowing the leadership to focus its energies in other areas.

The decision-making process in the consortium changed considerably over the years. The original community Advisory Committee, which initiated the partnership 14 years ago, was inoperative in the last years of the partnership. Thus, the task of providing direction to the partnership fell to a small, informally organized advisory committee. This committee, however, did not have a formalized decisionmaking process, so meetings were focused on sharing information on the program activities and fund raising efforts to supplement the budget of the partnership.

The compact, by contrast, expanded decision making and participation through its large compact council and the special committees and task forces. A formalized decision making process was in place and records of all meetings were maintained. The compact council meetings were lead by one of the co-directors and followed an agenda devised by the Operations Group.

Mechanisms for sharing information. The consortium relied on its newsletter in order to share information with the participating institutions. In addition, the Advisory Committee disseminated information to the university and the 
school district, each of whom had a member on the Advisory Committee. Yet, while the Consortium shared information via several channels, it still lacked a mechanism for using the information to facilitate inter-institutional dialogue, consensus building, and planning.

The compact Council served as the primary vehicle for sharing information among the compact partners. The compact meetings were used to share first-hand information about its activities, proposals, research and professional development activities. Moreover, the decision making process facilitated inter-institutional dialogue concerning on-going issues.

organizational change. The consortium facilitated the Bedford school district's encouragement of parent involvement, leading to parent and student contracts in some schools. In accordance with these contracts, parents were obliged to monitor their children's homework time, and students were committed to fulfill their obligation to attend school prepared to learn. The working relationship between the university and the school district has also improved, as evidenced by the continuation of the summer program and the initiation of a new college access initiative.

The Compact's strategy focused on facilitating programs and activities that were ultimately the responsibility of the institutions. In this process, the compact designated 
institutional change as a priority of all its activities. significant institutional change was reported to have been achieved in the redesign of school curriculum, increased professional development activities, and college recruitment strategies.

Improved relations between college and school staffs. Both partnerships focused on improved levels of trust between the school and college staffs. The compact initiated faculty dialogues designed to build trust and improve communication between school and college staffs. In addition to serving as a vehicle for an exchange of ideas among faculties from the same disciplines, the dialogues increased the frequency and level of communication between the school and college faculties, and informed both groups about the needs and difficulties of their respective tasks. The compact had sponsored two different faculty dialogues yearly since 1983 each with a different focus. The 1993-1994 dialogues emphasized the "Bio-Medical curriculum," while the 1994-1995 focus was "Applied Mathematics."

Funding. Because the consortium was funded almost exclusively by the Bedford schools, its survival after the third year was dependent on the availability of district funds. Since this situation did not demand a financial commitment from the other participating institutions, it is vlear why people this program was seen as belonging to the school district. When district funding ended, so did the 
Consortium. The compact, on the other hand, was supported by each institution with in-kind contributions to support those who served as leaders and staff. Other external funds, called renewable funds, were accessed by the institutions to provide services, for partnership building, and institutional development.

Balance between the members of the partnership. The members in the compact expressed satisfaction with the balance of responsibilities, authority and decision-making in the partnership. In-kind support was provided in equal proportions, and written agreements and delineation of responsibilities were formalized by the Administrative Council. Partnership members were represented proportionally in the Administrative Council. Decisions followed a consensus approach, providing all partners an opportunity to be heard and to influence decision making.

The Consortium, Advisory Committee consisted primarily of one representative from each school district, the university and the Parent Advisory committee. Notwithstanding the presence of these representatives, the absence of a written agreement and the disproportionate funding exacerbated the imbalance of responsibilities and mitigated directives to rectify this situation.

student success. The two partnerships differed in their approach to the academic preparation and college enrollment of their students. The Consortium attempted to 
improve academic success by carrying out supplemental activities and programs with students and their parents. Those activities (essay contests, speaking competitions, college visits, and parent student contracts) were separate from mainstream school activities and were assumed to have a positive impact on academic preparation.

The compact, on the other hand, focused on generating changes and improvements in the day to day operation and services of the participating institutions. Some of those changes and improvements, designed to facilitate high school preparation and college enrollments, included: curriculum reform in math and science; improving access to entry level math and science courses; improved professional development among staff; and the collection of data on student achievement. The compact also created a task force on student services and recruitment in order to coordinate postsecondary outreach. Partly as a result of this effort, the percentage of minority seniors continuing in public colleges increased from 33.78 in 1985 to 53.28 in 1991.

College retention. Retention of minority students in postsecondary institutions.

College retention was not a priority of the Consortium and was not addressed by any of its actions. The compact on the other hand began to focus its efforts more sharply on college retention. It received funds to design a postsecondary evaluation plan on the transfer of community 
college students to four-year institutions. The state university initiated a community college transfer program to introduce community college students to the campus during an eight-week residential summer experience.

partnership development. There was no indication that partnership formation and development were recognized concerns of the consortium. The compact, by contrast, had always paid careful attention to partnership development, beginning with a lengthy partnership development effort which produced a handbook on $\mathrm{K}-12$ postsecondary partnership development. Within the compact there was a deliberate attempt to examine, study and disseminate information about partnership formation and development.

Chapter $V$ discusses the results of the study, its implications, the limitations of this research, and examines areas for further research. 


\section{CHAPTER V}

CONCLUSIONS AND RECOMMENDATIONS

Comprehensive partnerships which focus on minority and disadvantaged students are an important recent development in interorganizational collaboration. This study surveyed 16 of those partnerships. The study concluded that:

- A majority are formally organized by written agreements.

- Ninety percent of the partnerships included a coordinator and more than half (56\%) employ a full-time coordinator or director.

- Most are also guided by a committee representing the partner institutions

- More than $80 \%$ of the respondents indicated that their partnership defined and monitored their goals.

- A significant number of respondents (64q) claim that the partnership is successful in achieving its goals. Most respondents (998) consider their partnerships at least somewhat successful in attaining their objectives.

- Almost half of the partnerships had yearly budgets of more than $\$ 300,000$.

- The preparation of minority high school students has been improved substantially, according to $60 \%$ of the 
respondents, and with some success according to $36 \%$ of the respondents.

- High school graduation data are systematically collected to measure success by many of the partnerships (90\%), as are college preparatory course enrollment data (66\% of respondents); grade point average (60\% of respondents); and SAT scores (59\% of respondents).

- outcome data on student placements after high school graduation, however, are less available and indicate more limited success. College enrollment and college graduation data are collected in considerably fewer cases than are high school graduation data; only 468 of respondents said that their partnership collected college graduation data while 908 said high school graduation data were collected. College enrollment data is collected according to $78 \%$ of the participants.

- Increases in the college enrollment of minority students have been achieved to a substantial degree according to $52 \%$ of respondents, and to some degree according to 448 of the respondents.

- college retention of those students was achieved to a lesser degree. Only $22 \%$ of respondents reported retention had been achieved substantially, and to some degree, according to 448 of the respondents.

- Data on the financial support of the college enrollees, potentially a very important determinant of 
college persistence, were gathered according to only $31 \%$ of the participants, and $68 \%$ indicated that their partnerships do not collect that data.

- Substantial institutional change and reform as a result of the partnerships were attained to a substantial degree according to only $10 \%$ of the respondents and to some degree, according to $55 \%$ of respondents. But, it was not an objective to 238 of the respondents.

- The leadership of one individual and collaboration among the participating institutions are the most influential factors in the formation of the partnerships.

Two partnerships which indicated that they had accomplished their objectives to a substantial degree were selected for case studies. They were also selected because they were the most accessible, had significantly different levels of funding, and provided an opportunity to compare and contrast two successful partnerships, one which was thriving and another that had been "transformed."

In-depth interviews were conducted during visits to the two sites. The interviews focused on the relationship of the partnerships to the success characteristics identified in the partnership literature: the importance of leadership, shared decision-making, exchange of information, commitment to a long-term relationship, development of trust, adequacy of support, and receptiveness to the dynamic nature of partnerships. Five key informants from each of 
the two institutions participating in the partnerships were interviewed on site. An interview protocol served as a guide for open-ended questions regarding the characteristics of the partnership which contributed to their success.

\section{The Importance of Leadership}

Leadership is recognized as an important factor in organizational performance. Yukl (1989), in his comprehensive review of studies on the influence of leadership on organizational performance, concluded that "studies indicate moderate to strong influence of leaders on organizational performance" (p. 287).

The importance of "leadership" in the formation and maintenance of partnerships whose goals are to improve minority and disadvantaged student success in postsecondary education was a salient finding of this study. The site visits and interviews revealed that these partnerships are propelled by effective leadership at three different levels: (a) the institutional Chief Exccutive officer (CEO) level,

(b) the partnership Director level, and (c) the institutional representative (middle manager) level.

\section{CEO Leadership}

Forty-one percent of the respondents to the study's survey indicated that the leadership of one individual was the most significant factor in the formation of their partnership. The partnerships were frequently initiated 
with the support of institutional Chief Executive officers (CEO's). The postsecondary education leaders were usually concerned about increasing the access and academic preparation of the growing population of minority college age youth. Public school leaders wexe concerned about their ability to develop the academic skills of these same students and prepare them for success in postsecondary education. Effective leadership helped to create a common interest in minority and disadvantaged student preparation and bring institutions together into a mutually and societally beneficial relationship.

This symbolic and operational leadership of the institutional CEOs has been essential to partnership formation and maintenance. While their presence was not always necessary, periodic attendance and key support by the CEOs at partnership meetings was symbolically significant. The presence and full participation of the institutional CEO is important because of the legitimacy such support provides to the partnerships. In addition, their participation communicated the importance of the partnership to the institutions and encouraged the participation of the middle managers and staff of the institutions.

CEOs are most helpful to partnerships when they institutionalize partnership activities by making managers and leaders accountable for the implementation of partnership programs in their institutions and in turn use 
these initiatives to facilitate organizational reform and change within their institutions.

The importance of CEO leadership is particularly apparent when it is absent. The loss of supportive CEOs was particularly devastating to one of the study partnerships which had not created a mechanism for the involvement of other members of the institutions. The departure of the supportive CEO left the partnership with little support. Subsequent CEOs were not as invested in the partnership, and their detachment was reflected in the comments of interviewees from the university who made it clear that the university was not deeply involved with the partnership. As this case clearly demonstrated, the loss of the leadership of the CEO can be fatal to a partnership which relies too heavily on the leadership of one committed CEO for its survival.

\section{Executive Director Leadership}

While the leadership at the executive level (CEOs) and from the institutional managerial ranks greatly influenced partnership success, the leadership of the partnership directors--the persons with ultimate responsibility for the operation of the partnerships--was even more important. Goodlad (1990) once noted that these individuals play the role of partnership "worriers."

In this study, partnership directors were frequently identified as the most influential element of the 
partnerships development, success and actions. Both case study partnerships had only one director in their many years of operation and attributed their success to the commitment and perseverance of these individuals.

The role of the directors in school-college partnerships involving several institutions is especially crucial because each participating institution has a distinct culture, personnel and clientele. Partnership directors are most successful when they have a clear understanding of the culture of the different educational segments and can respond to their organizational priorities. In a sense, partnership leaders have to posses new and emerging leadership skills necessary to manage their enterprises in an environment which demands that schools and postsecondary institutions constantly respond to multiple societal forces.

The demand for new organizational leaders to manage the interplay between their organizations and these external forces has been recognized by leadership theorists who have pointed out that leaders need to accept and understand complexity and context, and are under great pressure to learn to manage these external forces and demands (Gardner, 1990; Bennis cited in Sergiovanni \& Corbally, 1986, p. 66). This challenge makes effective leadership especially critical. Schein (cited in Pugh \& Hickson, 1989) asserted that "the key to leadership is managing cultural change" ( $p$. 
197). The goal of successful partnerships is to change the culture (the way things are done) at the participating institutions by introducing new technologies, establishing fresh priorities, collecting appropriate data, and ultimately changing the composition and performance of students, as well as increasing the sensitivity and skill level of the faculty and staff.

Successful partnerships, then, merge facets of organizations into the pursuit of common goals. Schein (1987) asserted that the need to create cultural compatibilities between organizations is often ignored and warned that this indifference causes anxiety and dislocation. Schein continued to note that an initial shaping force in organizations is the personality and belief system of the founding leaders. The founder and director of one of the partnerships in this study recognized that members within the partnership represent diverse cultures with distinctive norms and language, and noted that sustaining appropriate leadership and organizational momentum would be crucial to lasting success. The fact that he recognized and responded to diversity within the partnership may have contributed to the general high regard in which others held him.

The most successful partnership in this study engaged in lengthy organizational actions which included a planning period designed to develop a process for action. The 
publication released by that partnerships at the conclusion of its first year of planning included a chapter on sustaining leadership and momentum. The leadership style of this particular partnership director was characterized by the interviewees as "transformative leadership" (Nanus, 1992 , p. 8). Such a leader has the capacity to take an organization to a place it has never been. Nanus discusses the ability of the transformative leader to reach the "souls" of others in a fashion which raises human consciousness, builds meaning, and inspires human interest. of prime importance in transformational leadership is vision, purpose, beliefs and an understanding of organizational culture.

This function of leadership is particularly useful to partnerships because member organizations unite to explore new arenas and to achieve new objectives which the individual partner organizations cannot achieve independently. Partnership formation is full of ambiguities and doubts, and nothing assists in the minimization of these ambiguities better than leadership characterized by direction, clear communication and the empowering of the other participants.

\section{Middle Management Leadership}

The middle managers in this study were the directors of departments, programs or divisions and were responsible for the implementation of organizational policies and the 
operation of programs providing direct instruction and services to students in their institutions. Middle managers served as the link between the organizational CEOs and the staff and faculty who delivered services to students of the partinerships programs.

This study found that a critical mass of middle managers facilitated broader institutional change, provided an appropriate level of "buy in," and were essential to the achievement of partnership goals. Successful partnerships recognize the need to simultaneously implement top down and bottom up strategies for successful organizational change. What is necessary is the combination of consensus at the top and pressure from below for things to happen (Fullan, 1993). This requires a balanced interactive relationship involving pressure, support and constant negotiation. Middle managers are essential in facilitating this relationship.

Middle level leaders serve as the conduit between organizational policies and the implementation of those policies through program delivery. Middle managers help to translate the "pressure from below," which Fullan asserts is essential for meaningful change, and they assume the leadership in the delivery of programs and services which create change in the performance and preparation of students. The most desired characteristics of middle level leaders within partnerships include commitment to the goal 
of interorganizational cooperation and awareness of the partnership's history, goals, and organizational culture. Middle level managers are most effective when they are part of institutional teams. A team approach is beneficial for the following reasons: (a) the combination of symbolic and management leadership offers the essential tension and support for the partnership to accomplish its tasks. While CEOs provide the symbolic leadership, middle managers and the director are needed to actualize the plans and policies of the partnership; (b) the involvement of several participants makes it possible for the member institutions to maintain a collective historical awareness of the partnership goals and accomplishments. Reliance on only one person limits that history and narrows the objectives; (c) the middle managers help provide continuity to the participation of the institutions even when the CEOs leave their institutions; (d) multiple members can keep information flowing within and to their respective institutions in order to increase continued awareness of the partnership activities.

In conclusion, effective partnership leadership needs to include three important levels (CEOs, Director, Middle Managers) and is most effective when the executive director understands and helps to create a new organizational culture by involving the partners in creative problem solving. In successful partnerships, leadership is particularly 
effective when it builds an organizational structure that allows the partners to share equally in the support, responsibilities and benefits of the partnership.

Some important lessons have been learned as a result of this study those lessons include; the importance of appropriate leadership and the creation of partnerships that take into consideration the organizational dynamics of the participating institutions. The role of leadership in partnership formation and operation is crucial. In addition to building consensus, establishing a clear agenda and building trust, successful leaders should strive to imbed the partnerships within the participating institutions rather than creating satellite organizations. The evidence of this research suggests that imbedded partnerships have a better chance of surviving and influencing the direction of the participating institutions. Successful leaders should also have the ability to; relate to the different organizational cultures involved in the partnership, serve as spokespersons, undertake the periodic renewal of the partnership as an organization and acquire the external resources needed to initiate new programs.

\section{Partnerships as organizations}

organizations are social units deliberately constructed and reconstructed to seek specific goals. They are characterized by: 1) divisions of labor, power and communication responsibilities; 2) the presence of one or more 
power centers; 3) substitution of personnel. (Etzioni, 1964, p. 3)

It is important to recognize that partnerships, especially the kind of comprehensive partnerships in this study, are also organizations. Yet it seems clear from this research that partnerships stand to fundamentally change the organizations involved in relation to the three characteristics of organizations noted above.

Division of Labor, Power, and Communication Responsibilities

The division of labor and power is carried out differently in partnerships than in traditional organizations because partnerships by nature require a more consultative approach to the division of power and labor. In most traditional organizations the lines of power and authority are relatively clear--persons with designated authority make decisions about the tasks to be pursued in order to meet organizational needs, and they assign to individuals the responsibility to perform those tasks. Individuals are held accountable for their performance, and these are usually linear reporting arrangements in which the person with authority determines whether or not tasks were achieved satisfactorily.

In partnerships, however, the definition of responsibilities is often made by persons who do not have complete authority over those who will perform required tasks. Power and authority is diffused across the spectrum 
and placed on policy boards and committees rather than on supervisors. Therefore, more extensive negotiations take place in partnerships in order to acquire the acceptance of roles and responsibilities by the participants. Such negotiations, if they are to bear fruit, must consider the partnership's needs and place them above the needs of traditional organizations.

The division of labor, power, and communication responsibilities in partnerships are addressed most effectively by the creation of a policy board or coordinating committee that includes broad representation from the participating institutions. It is helpful to approach the distribution of labor and power by using what Owens (1991) labeled the "normative-reeducative strategy to organizational change." This strategy is based upon an understanding of organizations which holds that the norms of the organization's system (attitudes, beliefs and values-its culture) can be deliberately shifted to more productive norms through collaborative action of the people who populate the organization.

Decision-making, then, ought to be approached from what Hall (1977) called the "dual rationality standpoint" ( $p$. 161), in that both problems and politics are involved. participants in decision-making must be concerned with the problem at hand as well as the political process necessary to develop support for positions and decisions to be made. 
The inclusion of all parties in decision-making allows for a discussion of the problems and an awareness of organizational politics in order to address solutions. Therefore decisions must be made in a fashion which guarantees not only an opportunity to articulate problems but also to consider the institutional dynamics that make it possible for the problems to be solved. Decisions reached by consensus are usually recommended because that process assures broad input and facilitates the support of all parties.

Thus, one of the essential characteristics of successful partnerships is the existence of a structure that is conducive to open decision-making, inclusiveness and participation. That structure should include a policy board and smaller subcommittees which can analyze issues in detail and make recommendations to the policy board. The board should be responsible for the assignment of committee leadership and responsibilities.

A productive division of labor over funding is one area in which equal participation by all the participating institutions is especially crucial. organizations which invest financial and personnel support are more committed to their investment. One sided financial and resource support thus contributes to imbalances in the degree to which the participants view their responsibility in the partnership. 
For this reason, relative equity of support helps insure a more productive division of labor among members. In addition to sharing in the funding of the organization, some of the partnership's funds and resources must be dedicated to its own renewal. The need for renewal is not limited to partnerships. In order to adapt, all organizations must know how and why human systems change. Gardner (1990) asserted that all organizations must incorporate a process of renewal because, "motivation runs down, values decay and the present problems may go unsolved while people mumble about the slogans of yesterday" ( $p$. 121). The process of renewal, according to Gardner, is consistent with the value distinction between transactional and transformational leadership. Transactional leadership according to Gardner's definition, accepts and works within the status quo structure. By contrast, transformational leadership renews. The purposes of renewal are to: reinterpret existing values and generate new values, re-energize forgotten goals, foster the release of human potentials through education and lifelong growth (p. 122). The existence of transformational leadership in the most successful partnership in this study was described in this chapter's section on the importance of leadership. Part of the impact of the transactional leadership on this partnership has been the institutionalization of a renewal process. The successful partnership engaged in a renewal 
process yearly. It used a two-day retreat to reevaluate its previous goals and values, craft new goals and analyze the data on the successes of the previous year. That partnership also took time to celebrate and recognize the accomplishments of the deserving individuals and organizations. In addition, time is spent at the yearly retreats to evaluate the efficacy of the communication between the institutional members, and make new task force and committee appointments. All the CEOs and the members of the Administrative Council participate in the yearly renewal retreat.

\section{Presence of More than one} Power Center

Unlike traditional organizations, in which power is concentrated in hierarchical structures, power is more diffused in partnerships. The power centers are brought together in the policy board in the person of the cEOs. They come together to share the decisions made about the division of labor and the priorities of the partnership. The establishment of a policy board or coordinating committee that includes all levels of the participating institutions helps to include the major power centers. In addition to the cEOs the policy board should also include the middle level managers and the partnership directors. The middle managers have the power to make decisions and distribute the labor within their 
organizations. They are the individuals who remain in: contact with the organization's top decision makers and are also able to speak for the rank and file of the institutions.

The partnership directors represent the interests of all the participating institutions. Their challenge is to impartially coordinate the contributions of the various power centers while diffusing conflicts between them. The power of the directors is "coercive" rather than "authoritative." Their power is based on their ability to build consensus about goals and strategies, obtain resources, coordinate the planning processes, and share data and information that informs the decision-making process.

The Toledo compact has successfully incorporated all the elements discussed above in its approach to accommodating the presence of diverse power centers. There is widespread recognition by the participants of the effectiveness of this approach. Power conflicts are not present in this partnership and all the members believe/ that recognition and rewards are distributed equally. The level of trust and cooperation is very high.

The Bedford Consortium on the other hand, did not include the CEOs or middle managers in its governance structure and as a consequence had very limited support from the institutional power centers. Its original policy board, the Community Advisory Committee, did not incorporate a 
process of periodic renewal and "burned out" after a few years.

\section{Substitution of Personnel}

Traditional organizations typically substitute personnel through a selection/hiring process that involves their personnel specialists, supervising mangers and in some cases the current employees. New personnel are selected from available candidates/applicants based on their skill, experiences and the ability to fit the organizational culture and needs.

Partnerships follow a significantly different process. Participating institutions typically appoint their representatives to serve in policy and staff positions, member institutions also make decisions about their substitution. The assignment and substitution of institutional participants and staff to partnerships is usually done by the CEO or other top level administrators. since they are rarely in a position to select institutional representatives it is important that partnerships follow three steps to attract personnel that fit their organizational culture. The first step is to seek the assistance of the cEOs in the appointment of the appropriate personnel. The appointment and substitution of institutional personnel to the partnerships is one of the important functions of the participating CEOs. They should be given guidelines to follow as they contemplate the 
appointment of institutional representatives. Ideally appointees and substitutes should meet the following criteria: (a) an interest in partnerships and collaboration, (b) sufficient institutional stature and authority to facilitate change, and (c) the ability to participate for a lengthy period of time. The appointment of personnel that can make a long-term commitment is important because it gives them an opportunity to implement desired changes and programs, and allows them to develop a historical perspective on the partnership's work. The use of the aforementioned criteria may also serve as a safety measure against the appointment by cEOs of inefficient or uninterested personnel to the partnership.

As a second step the partnership director and the institutional representatives should constantly identify new and existing personnel within the institutions who have interest, commitment and expertise in partnerships and collaboration. Such personnel should be identified and every effort made to include them as volunteers in partnership activities in order to prepare them to substitute current appointees. Appointment to on-going task forces and committees is an ideal training ground for potential new participants.

The third step consists of conducting proper orientations for incoming appointees and volunteers. The partnership director and the staff have a special 
responsibility in the orientation of new participants. They are in a unique position to provide information on the history, philosophy and success of the partnership and to make them aware of all the current activities and programs. They should also include them in the renewal retreats, program recognition events, public relations activities and planning meetings. The goal of the orientation activities should be to give new participants a sense of belonging and commitment to the partnership.

\section{Limitations of this Research}

The greatest limitation of this study is that the responses to the survey questionnaires were self reported by the respondents, and thus the information provided on the characteristics and the success of the partnerships reflected the opinion of the three individuals identified by the partnerships to respond to the survey.

Those responses represented the opinions of the respondents based on their experiences and were not always readily verified by the researcher. For example, the survey respondents from one of the partnerships selected for case study indicated that a written agreement was used to establish the partnership. However, the site visit and interviews revealed that a written agreement between the member institutions in that partnership never existed. This finding was significant because the existence of a written 
agreement was one of the characteristics that classified that partnership as successful and led to its selection for a case study. That same partnership also indicated that it had increased the postsecondary enrollment of its participants and that it collected data to verify that increase, but the case study revealed that it had not collected data to substantiate/that claim.

It was logistically impossible for the researcher to confirm the accuracy of all the self reported information on success reported in the surveys. The data reported by the 16 partnerships included rates of pre-college course enrollment, high school graduation rates, Grade Point Averages, SAT scores, college enrollment rates, and college graduation rates.

This research would be improved by the addition of a process to verify the accuracy of the survey responses and the existence of data to substantiate claims of success. Such an improvement would require a considerable increase of personnel and time.

\section{Additional Research Needed}

This research did not investigate the extent to which certain demographics influenced the decision to initiate school-college partnerships for minority and disadvantaged students. For example, two questions could be asked: (a) do $\mathrm{K}-12$ and postsecondary institutions located in regions 
with large percentages of minority students feel more urgency and pressure to form and support partnerships to improve the academic performance and college enrollment of these students, and (b) is there a correlation between the existence of school-college partnerships for minority students and the percentage of minorities in the geographic location.

The two case studies examined in this study are suggestive in this regard. The case study partnership in this study which enjoyed the greater degree of institutional commitment and support is located in an area with large percentages of minority students. Some of the institutional CEOs, including the school superintendent, and many of the institutional middle managers were "minority." They exhibited a strong commitment to improving educational opportunities and access for the minority students in the area. One of the strategies in the early phase of this partnership was to bring together minority professionals from the participating institutions who had a strong commitment to improve the educational opportunities of the minority students in the area. These individuals viewed the partnership as an opportunity to correct the inability of their institutions to serve minority students. Although it is not discussed, and the partnership has incorporated the participation of professionals from all ethnic backgrounds, that underlying commitment is still present. 
The second partnership was located in a predominantly White region, but served mostly minority students in a predominantly white school district. There was no significant minority community leadership nor minority middle management representation in the participating institutions. There was some resentment in this partnership about the existence of a partnership that focused primarily on minority and disadvantaged students.

The existence and participation of minority CEOs and middle managers in the operation of these partnerships can be an important contributor. Their commitment makes the partnerships acceptable within the institutions and give their staffs the support they needed to make the partnership a priority. Large minority populations in the geographic location of the partnerships tends to make the needs of these communities a priority of the local public and private organizations and provide the organizational and political leadership that is inclined to respond to the needs of minority students.

Further research is also needed to inquire about the reasons that data on the postsecondary performance (grades, test scores, academic support, graduation and financial support) of the partnership students were not collected to the same extent as secondary school performance data.

This exploration is needed because one of the primary reasons for the creation of these partnerships is the 
increase of academic preparation and college success of minority and disadvantaged students. It as assumed the partnerships are concerned about postsecondary as well as secondary academic success, but the data they collect do not reflect that assumption. In addition collecting data on postsecondary performance (grades, test scores, academic support, graduation and financial support) is necessary for the postsecondary institutions to design effective intervention strategies much as it is done in the $\mathrm{K}-12$ schools.

Further research is also needed to explore the reasons that the objectives related to postsecondary performance of the students in these partnerships (improved college retention, increased college graduations and increased college enrollments) were reported to have been achieved to a lesser degree than were secondary school objectives. The following questions should be asked. Are there reasons that improved academic performance for these students is more difficult to attain in postsecondary institutions? What are they? Are postsecondary institutions as committed as the K-12 institutions to improving the performance of these students? Is performance in postsecondary institution viewed as an individual student responsibility?

This research was undertaken to study comprehensive partnerships created to; improve the academic performance and college enrollment of minority and disadvantaged 
students, coordinate the work of multiple institutional levels, and promote college participation and success for those students in a wide range of majors and areas of concentration.

Given the pervasive call for educational institutions to create partnerships that address the needs of these students and the difficulties recognized in the achievement of the goals of these partnerships, it is perhaps not surprising that only small number of these collaboratives could be found in the search to identify the universe of these partnerships. The limited number of these partnerships and their importance to the educational enterprise makes it imperative to continue in depth studies into what allows those partnerships to survive and succeed. 


\section{REFERENCES}

American Council on Education and Education Commission of the states. (1988). one third of a nation: A report of the commission on minority participation in education and American life. Washington, DC: Author.

Astin, A. W. (1982). Minorities in American higher education: Recent trends, current projects and recommendations. San Francisco: Jossey-Bass.

Bacon, F. L. (1951). American schools and colleges, continuity or cross-purposes. The College Board Review, 13(2), 175-181.

Bailey, A. Y. (1986, November)! More than good intentions: Building a network of collaboratives. Education and Urban Society, 19(1), 7,23.

Baird, A. C., \& Porter, O. F. (1991). Partners in education: A directory of partnerships between independent colleges and universities and America's schools. Washington, DC: National Institute of Independent Colleges and Universities.

Barth, R. S. (1984, November 28). Can we make a match of schools and universities? Education Week, 4 (13), 24.

Blackmer, A. R. (1952). General education in school and college: A committee report. Cambridge, MA: Harvard University Press.

Bogdan, R. C., \& Biklen, S. K. |(1982). Qualitative research in education: An introduction to theory and methods. Boston: Allyn and Bacon.

Borg, W. R., \& Gall, M. D. (1983). Educational research: An introduction. New York: Longman.

Boyer, E. (1983a, September). The need for school/college collaboration. Higher Education and National Affairs, $\underline{32}(24), 11$.

Boyer, E. L. (1983b). High school: A report on secondary education in America. New York: Harper and Row. 
Bruner, J.S. (1960). The process of education. New York: Vintage Books.

Burkheimer, G., Riccobono, J. A., \& Wisenbaker, J. M. (1979). Evaluation study of the Upward Bound Program: A second follow-up. Research Triangle Park, NC: Research Triangle Institute.

Center for the Study of Partnerships. (1994). National school-college partnership electronic data base [Machine readable data file]. Syracuse, NA: Syracuse University.

Civil Rights Act of 1968, Fair Housing Title (Title VIII) (Pub. L. 90-284, 82 stat. 81), 42 U.S.C. $\$ 3601-3619$, 3631 (1970, Supp. 1975).

Comer, J. P. (1981). Toward school improvement: A study of collaborative relationships between universities and public schools. Report to the National Institute of Education. New Haven, CT: Yale University Press.

Coulson, J., Bradford, C., \& Kayne, J. (1981). Evaluation of the special services for disadvantaged students (SDSS) programs: 1979-80 academic year. Palo Alto, CA: Systems Development Corporation.

Curry, L. (1980, May). Teacher center as university district collaborations. Phi Delta Kappan, 61(9), 631-632.

Daly, W. T. (1985). Colleqe-school collaboration: Appraising the major approaches. Jossey-Bass. San Francisco.

Douglas, J. (1988). Urban school-university collaboration: A final report to the Ford Foundation. Milwaukee: Wisconsin University Press.

Elicker, P. E. (1956, Summer). The secondary principal looks at the admissions officer. College and University, pp. 423-434.

Etzioni, A. (1964). Modern organizations. Englewood Cliffs, NJ: Prentice Hall.

Evan, W. M. (1966). The organization set: Toward a theory of interlocking relations. In J. D. Thompson (Ed.), Approaches to organizational design (pp. 173-191). Pittsburgh: University of Pittsburgh Press. 
FilerMaker pro [Computer program]. (1992). Santa Clara, CA: Claris Corporation.

Freeman, F. (1992). Power in the pipeline: A new wave of multicultural partnerships. Washington, DC:

Association of Governing Boards of Universities and Colleges.

Frost, J.A. (1972). Time shortening and articulation. In W. L. Goodwin \& P. B. Mann (Eds.), Higher education myths realities and possibilities (pp. 236-249). Atlanta: South Regional Education Board.

Fullan, M. (1993). Change forces: Probing the depths of educational reform. London: Falmer Press.

Fund for the Advancemert of Education. (1953). Bridging the gap between school and college (Evaluation Report No. 1). New York: Author.

Galligani, D. J. (1987). Effective relationships for school/college partnerships: A qualitative evaluation of the curriculum enhancement projects participating in the California Academic Partnership Program 1984-1987. Long Beach: California state University Leng Beach, office of the Chancellor.

Gardner, J. W. (1990) - on leadership. New York: Free Press.

Gifford, B. R. (1986). The evolution of the school/university partnership for educational. Education and Urban Society, 19(1), 77-106.

Glaser, B., \& strauss, A. (1967). The discovery of grounded theory. Chicago: Aldine Publishing.

Gomez, M., Bissell, J., Danziger, L., \& Casselman, R. (1990). To advance learning: A handbook on developing k-12 postsecondary partnerships. New York: University of Press of America.

Goodlad, J. I. (1984). A place called school: Prospects for the future. New York: McGraw Hill.

Goodlad, J. I. (1990). Teachers for our nation's schools. San Francisco: Jossey-Bass.

Green, M. F. (Ed.). (1989). Minorities on campus: A handbook for enhancing diversity. Washington, DC: American Council on Education. 
Greenberg, A. R. (1982). High school/college articulated programs: Pooling resources across the abyss. National Association of secondary School Principals Bulletin, $\underline{56}(454), 66$.

Greenberg, A. R. (1991). High school college partnerships: Conceptual models, programs and issues (ASHE-ERIC Higher Education Report No. 5). Washington, DC: George Washington University, School of Education and Human Development.

Gross, T. I. (1988). Partners in education. San Francisco: Jossey-Bass.

Haberman, M. (1971, summer). Twenty-three reasons universities can't educate teachers. The Journal of Teacher Education, 22 (2), 133-140.

Hall, R. H. (1977) . Organizations: Structure and process (2nd ed.). Englewood Cliffs, NJ: Prentice Hall Inc.

Hammersley, M. (1992). Deconstructing the qualitative quantitative divide. In $J$. Brannen (Ed.), Mixing methods: Qualitative and quantitative research (pp. 39-55). Brookfield, VT: Avebury.

Hodgkinson, H. (1985). All one system. Washington, DC: The Institute for Educational Leadership Inc.

Hord, S. M. (1986, February). A synthesis of research on organizational collaboration. Educational Leadership, $\underline{43}(5), 22-26$.

Immigration and Naturalization Service. (1988). [Immigrants admitted by country of birth.] Unpublished raw data.

Intriligator, B. A. (1982, September/october). Interorganizational collaboration: A strategy for faculty development and organizational renewal. Journal of Teacher Education, 33(5), 14-17.

Ladd, E. T. (1969). Sources of tension in schooluniversity collaboration. Atlanta, GA: Urban Laboratory of Education. (ERIC Document Reproduction Service No. ED 031 034)

Lauter, P. (1968). The short and happy life of the Adams Morgan community project. Harvard Educational Review, 38(2), 235-262. 
Levine, A. (1989). Shaping higher education's future: Demographic realities and opportunities 1990-2000. San Francisco: Jossey-Bass.

Maeroff, G. (1983). School and college: Partnerships in education. Princeton, NJ: The Carnegie Foundation for the Advancement of Teaching.

Martin, D. A., Mocker, D. W., \& Brown, N. C. (1986). Joining forces for urban youth: The NASULGC urban university/urban school collaborative program. Washington, DC: National Association of State Universities and Land Grant Colleges.

Menacker, J. (1969, December). Subject articulation between high school and college. clearing House, $\underline{44}(4), 220$.

Menacker, J. (1975). From school to college: Articulation and transfer. Washington, DC: American Council on Education.

Mickelson, D. J., Kritek, W. J., Hedlund, R. D. , \& Kaufmann, A. M. (1988). Urban school-university collaboration: A final report to the Ford Foundation. Milwaukee, WI: University at Milwaukee.

Mingle, J. R. (1987). Focus on minorities: Trends in higher education participation and success. Denver: Education Commission of the states and the state Higher Education Executive officers Association.

Morgan, D. L. (1994, April 8). Approaches to combining qualitative and quantitative research. Paper presented at the meeting of the Portland State University Statistical Research Group, Portland, OR.

Mortenson, T. G. (1991, January). Equity of higher educational opportunity for women, Black, Hispanic and low income students (ACT student Financial Research Report Series, 91-1). Iowa City: American College Testing Program.

Nanus, B. (1992). Visionary leadership. San Francisco: Jossey-Bass Publishers.

National Commission on Excellence. (1983). A nation at risk: The imperative for educational reform. Washington, DC: Author. 
National Education Goals Panel. (1992). The national education goals report: Building a nation of learners. Washington, DC: U.S. Government Printing office.

Neal, D. C. (1988). Consortia and inter institutional cooperation. New York: Macmillan Publishing Company.

Odell, M., \& Mock, J. J. (1989). A crucial agenda making colleges and universities work better for minority students. Boulder: Western Interstate Commission for Higher Education.

Orfield, G. (1992, Fall). Money equity and college access. Harvard Educational Review, 62 (3), 337-372.

Otterbourg, S., \& Adams, D. (Eds.). (1989). Partnerships in education: Measuring their success. Largo, FL: Infomedia, Inc.

ottinger, C. A. (1989). Higher education today: Facts in brief. Washington, DC: American Council on Education, Division of Policy Analysis and Research.

Owens, R. G. (1991). organizational behavior in education (4th ed.). Englewood Cliffs, NJ: Prentice Hall.

Pugh, D. S., \& Hickson, D. J. (1989). Writers on organizations (4th ed.). Beverly Hills: Sage Publications.

Richardson, R. C. (1991). Achieving quality and diversity: Universities in a multicultural society. New York: American Council on Education and McMillan Publishing Company.

Richardson, R. C., \& Bender, L. W. (1987). Fostering minority access and achievement in higher education. San Francisco: Jossey-Bass.

Schein, E. H. (1987). Organizational culture and leadership. San Francisco: Jossey Bass.

Scott, H. V. (1977, Fall). Consortia in higher education: A sober reflection. Educational Record, 58(4), $429-433$.

Sergiovanni, T. J., \& Corbally, J. E. (1986). Leadership and organizational culture. Chicago: University of Illinois Press. 
Shulman, L. S. (1988). Disciplines of inquiry in education: An overview. In R. M. Jaeger (Ed.), Complementary methods for research in education ( $p p$. 3-20). Washington, DC: American Educational Research Association.

Sirotnik, K. A., \& Goodlad, J. I. (1988). School university partnerships in action: Concepts, cases, and concerns. New York: Teachers College Press.

Sizer, T. R. (1984). Horace's compromise: The dilemma of the American high school. Boston: Houghton Mifflin Company.

Smith, R. B., Jr. (1988). School college collaboration: A case study of Lilly endowment linkage grants in Indiana. Unpublished doctoral dissertation, Harvard University, Cambridge, MA.

Stanfield, R. L. (1981, Spring). Teamwork for high schools and colleges. Educational Record, 62(2), 45-47.

Statview [Computer program]. (1988). Berkeley, CA: Abacus Concepts Inc.

Stoel, C., Tognery, W., \& Brown, P. (1992). What works: School/college partnerships to improve poor and minority student achievement. Washington, DC: American Association for Higher Education, office of School/College Collaboration.

Traxler, A. E., \& Townsend, A. (1953). Improving transition from school to college. New York: Harper and Brothers Publishers.

Trubowitz, S., Duncan, J. Fibkins, W. , Longo, P., \& Sarason, s. $(1984)$. When a college works with a public school: A case study of school-college collaboration. Boston: Institute for Responsive Education.

U.S. Department of Education. (1993). The condition of education. Washington, DC: office of Educational. Research and Improvement, National Center for Education statistics.

Van de Water, G. B. (1989). The governance of schoolcollege collaboratives: Lessons learned from the EQ models program. New York: The college Board. 
Vivian, J. R. (1986, November). Issues in establishing and developing an educational collaboration: The Yale-New Haven experience. Education and Urban Society, 19(1), 59-76.

Westat. (1992). Reaching for College Volume 1: Directory of School college partnerships. Rockville, Maryland: U.S. Department of Education.

Western Interstate Commission for Higher Education (WICHE) . (1989). A crucial agenda: Making colleges and universities work better for minority students. Boulder, CO: Author.

Wilbur, F., \& Lambert, L. (1991). Linking America's schools and colleges: Guide to partnerships and national directory. Washington, DC: American Association for Higher Education.

Wilbur, F. P., Lambert, L. M. \& Young, M. J. (1988). School-college partnerships: A look at the major national models. Reston, VA: National Association of Secondary School Principals.

Wilson, R., \& Melendez, S. (1989). Minorities in higher education: Third annual status report. Washington, DC: American Council on Education.

Yukl, G. A. (1989). Leadership in orqanizations. Englewood cliffs, NJ: Prentice Hall Publishers. 
APPENDIX A

LIST OF PARTNERSHIPS 


\begin{tabular}{|c|c|c|c|}
\hline \multicolumn{4}{|c|}{ PARTNERSHIPS } \\
\hline NAME & HOST & SCOPE & SOURCE \\
\hline The Think Tank & $\begin{array}{l}\text { Maricopa } \\
\text { Community Colleges }\end{array}$ & $\begin{array}{l}\text { Multi-institutional } \\
\text { collaborative with } \\
\text { community } \\
\text { involvement } \\
\end{array}$ & $\begin{array}{l}\text { Stoel and Tognery } \\
\text { p.76 }\end{array}$ \\
\hline $\begin{array}{l}\text { The Toledo School } \\
\text { College Compact }\end{array}$ & $\begin{array}{l}\text { State University at } \\
\text { Toledo }\end{array}$ & $\begin{array}{l}\text { Multi-institutional } \\
\text { collaborative with } \\
\text { community } \\
\text { involvement }\end{array}$ & $\begin{array}{l}\text { Stoel and Tognery } \\
\text { p.76 }\end{array}$ \\
\hline $\begin{array}{l}\text { Hispanic Student } \\
\text { Success Program }\end{array}$ & $\begin{array}{l}\text { Hispanic Association } \\
\text { Colleges and } \\
\text { universities San } \\
\text { Antonio Texas }\end{array}$ & $\begin{array}{l}\text { Multi-institutional } \\
\text { collaborative with } \\
\text { comm. involvement }\end{array}$ & $\begin{array}{l}\text { Stoel and Tognery } \\
\text { p.78 }\end{array}$ \\
\hline Project Prime & $\begin{array}{l}\text { Arizona State } \\
\text { University }\end{array}$ & $\begin{array}{l}\text { Multi-institutional } \\
\text { coll. with comm. } \\
\text { involvement }\end{array}$ & $\begin{array}{l}\text { Stoel and Tognery } \\
\text { p.81 }\end{array}$ \\
\hline $\begin{array}{l}\text { Pace Liberty } \\
\text { Partnerships } \\
\text { Program }\end{array}$ & Pace University & $\begin{array}{l}\text { Multi-institutional } \\
\text { coll. with comm. } \\
\text { support }\end{array}$ & $\begin{array}{l}\text { Wilbur and Lambert } \\
\text { p.7 }\end{array}$ \\
\hline $\begin{array}{l}\text { Tell Them we are } \\
\text { Rising }\end{array}$ & Temple University & $\begin{array}{l}\text { Multi-institutional } \\
\text { collaboration. with } \\
\text { comm. involvement. }\end{array}$ & $\begin{array}{l}\text { Wilbur and Lambert } \\
\text { p.11 }\end{array}$ \\
\hline $\begin{array}{l}\text { New Partnerships } \\
\text { for Work and } \\
\text { Learning }\end{array}$ & $\begin{array}{l}\text { Burlington } \\
\text { Community College }\end{array}$ & $\begin{array}{l}\text { One higher education } \\
\text { institution, } \\
\text { community and } \\
\text { schools. }\end{array}$ & $\begin{array}{l}\text { Wilbur and Lamber } \\
\text { p.14. }\end{array}$ \\
\hline $\begin{array}{l}\text { Cleveland Initiative } \\
\text { in Education }\end{array}$ & $\begin{array}{l}\text { Case Western } \\
\text { Reserve Univ. }\end{array}$ & $\begin{array}{l}\text { One institution } \\
\text { schools and } \\
\text { community } \\
\end{array}$ & $\begin{array}{l}\text { Wilbur \& Lamb } \\
\text { p. } 18\end{array}$ \\
\hline ACCESS 2000 & $\begin{array}{l}\text { Loyola University of } \\
\text { Chicago }\end{array}$ & $\begin{array}{l}\text { Several higher ed. } \\
\text { institutions, } \\
\text { schools, community }\end{array}$ & p.36 \\
\hline The Boston Compact & \begin{tabular}{|l|} 
Boston School \\
College \\
Collaboration \\
\end{tabular} & $\begin{array}{l}\text { Mulli-institulional } \\
\text { coll. business and } \\
\text { comm. support }\end{array}$ & \\
\hline $\begin{array}{l}\text { Colorado VIP Student } \\
\text { motivation and } \\
\text { recruitment } \\
\text { program }\end{array}$ & $\begin{array}{l}\text { Univ. of Denver } \\
\text { West High School }\end{array}$ & $\begin{array}{l}\text { Multi. higher ed. } \\
\text { institutional/multi } \\
\text { secondary }\end{array}$ & $\begin{array}{l}\text { NIICU Directory of } \\
\text { Partnerships } \\
\text { p. } 8\end{array}$ \\
\hline $\begin{array}{l}\text { Education } \\
\text { Consortium of } \\
\text { Central Los Angeles }\end{array}$ & $\begin{array}{l}\text { University of } \\
\text { Southern California }\end{array}$ & $\begin{array}{l}\text { Multi-institutional } \\
\text { multischool comm. } \\
\text { collaboration }\end{array}$ & $\begin{array}{l}\text { NIICU Direclory } \\
\text { p.8 }\end{array}$ \\
\hline
\end{tabular}




\begin{tabular}{|c|c|c|c|}
\hline $\begin{array}{l}\text { Improving High } \\
\text { School Transition } \\
\text { lor Inner City } \\
\text { Students/University } \\
\text { Scholars Program } \\
\end{array}$ & $\begin{array}{l}\text { Columbia College } \\
\text { Northern lllinois U. } \\
\text { Crane and View High } \\
\text { Schools }\end{array}$ & $\begin{array}{l}\text { Two higher Ed. two } \\
\text { secondary } \\
\text { institutions }\end{array}$ & $\begin{array}{l}\text { NIICU directory } \\
\text { p. } 15\end{array}$ \\
\hline $\begin{array}{l}\text { Black Student } \\
\text { Achievement } \\
\text { Program }\end{array}$ & $\begin{array}{l}\text { Hood College } \\
\text { Maryland, Mt St } \\
\text { Mary's College } \\
\text { (Emmitsburg) }\end{array}$ & $\begin{array}{l}\text { Multi-institutional } \\
\text { coll. }\end{array}$ & $\begin{array}{l}\text { NIICU Directory } \\
\text { p.21 }\end{array}$ \\
\hline $\begin{array}{l}\text { Minnesota Minority } \\
\text { Education } \\
\text { Partnership }\end{array}$ & $\begin{array}{l}\text { St. John's } \\
\text { University }\end{array}$ & $\begin{array}{l}\text { Multi-institutional, } \\
\text { community support }\end{array}$ & $\begin{array}{l}\text { NIICU Directory } \\
\text { p. } 27\end{array}$ \\
\hline $\begin{array}{l}\text { San Antonio } \\
\text { Education } \\
\text { Partnership }\end{array}$ & $\begin{array}{l}\text { ST. Mary's } \\
\text { University }\end{array}$ & $\begin{array}{l}\text { Multi-institutional } \\
\text { coll. community } \\
\text { support, school } \\
\text { support }\end{array}$ & $\begin{array}{l}\text { NIICU Directory } \\
\text { p. } 52\end{array}$ \\
\hline $\begin{array}{l}\text { Fairfax County } \\
\text { Public School } \\
\text { Partnership }\end{array}$ & $\begin{array}{l}\text { Roanoke College } \\
\text { (Roanoke Virginia) }\end{array}$ & $\begin{array}{l}\text { Multi-institutional, } \\
\text { multischool, }\end{array}$ & $\begin{array}{l}\text { NIICU Directory } \\
\text { p. } 54\end{array}$ \\
\hline $\begin{array}{l}\text { The Bedford } \\
\text { Consortium for } \\
\text { School Achievement }\end{array}$ & $\begin{array}{l}\text { Lake Harbor } \\
\text { University }\end{array}$ & $\begin{array}{l}\text { One college schools } \\
\text { and minority } \\
\text { community support } \\
\text { (Urban league) }\end{array}$ & $\begin{array}{l}\text { NIICU Directory } \\
\text { p. } 55\end{array}$ \\
\hline $\begin{array}{l}\text { Haywood County } \\
\text { Public/Private } \\
\text { Educational Compact }\end{array}$ & $\begin{array}{l}\text { Haywood Community } \\
\text { College }\end{array}$ & $\begin{array}{l}\text { Consortia Multiple } \\
\text { Colleges, Multiple } \\
\text { Schools. Minority } \\
\text { Disadvantaged/At } \\
\text { Risk Corporate } \\
\text { Parental and } \\
\text { Community } \\
\text { Involvement }\end{array}$ & $\begin{array}{l}\text { Center for the } \\
\text { Study of } \\
\text { Partnerships } \\
\text { Database Search } \\
\text { Syracuse University }\end{array}$ \\
\hline $\begin{array}{l}\text { Simmons College- } \\
\text { School Consortium }\end{array}$ & Simmons College & $\begin{array}{l}\text { Consortia Multiple } \\
\text { Colleges Multiple } \\
\text { Schools Minority } \\
\text { Disadvantaged } \\
\text { At/Risk Enrichment } \\
\text { Programs Upward } \\
\text { Bound Faculty } \\
\text { Exchanges } \\
\text { Tutoring/Volunteer } \\
\text { Program } \\
\end{array}$ & $\begin{array}{l}\text { Center for the Study } \\
\text { of Partnerships. } \\
\text { Syracuse University }\end{array}$ \\
\hline $\begin{array}{l}\text { Community Alliance } \\
\text { to Support Education }\end{array}$ & $\begin{array}{l}\text { University of } \\
\text { Charleston }\end{array}$ & $\begin{array}{l}\text { Comprehensive } \\
\text { Local Partnerships } \\
\text { College Courses for } \\
\text { H.S. students } \\
\text { Minority } \\
\text { Disadvantaged } \\
\text { At/Risk } \\
\text { Enrichment } \\
\text { Programs. }\end{array}$ & $\begin{array}{l}\text { Center for the Study } \\
\text { of Partnerships. } \\
\text { Syracuse University }\end{array}$ \\
\hline
\end{tabular}


APPENDIX B

DATA SEARCH REQUEST 


\section{MEMORANDUM}

To: Dr Frank Wilbur

From: Armando Laguardia

Date: November 10, 1993

It was a pleasure speaking with you the other day. Your assistance and support are very appreciated .

I have enclosed with my dalabase search request, a list of the characteristics of the partnerships I intend to study, to assist you and your staff in the database search. Please use it in addition to the "search parameters" in the request form to idenlify the partnerships I am seeking. When in doubt include the partnerships in question for my consideration.

Please call me with any question at (503) 280-0643. My address is 3916 N.E. 8th Ave. Portland. Oregon 97212.

Thank You. 


\section{THE NATIONAL SCHOOL-COLLEGE PARTNERSHIP DATABASE REQUEST FOR DATABASE SEARCH}

\section{Charges for Services}

Suarch. A charge of $\$ 65$ includes a comprehensive searcli of any or all of the four major parts of the database and a search report, first class shipping and handling included.

Jou may narrow your search request without extra charge by specifying any of the following: grade level geographic area, one or more of the subcategories under each of the major parts, and/or any of the focus codes.

The information provided with all search reports includes the name of the sponsoring higher education institution, the name of the partnership, its reference number, and the name, title, address, and telephone number of the higher education contact person for the partnership.

Labels. Pressure-sensitive mailing labels are available in either one-across or four-across, pin-feed format; the size of each address label is $1.5 \times 4.0$ inches. The charge for labels is $\$ 10$ per 100 (minimum charge, $\$ 20$ ). Shipping and handling are included. Since the number of labels to be generated is unknown until after the custom search has been completed, include the minimum charge of $\$ 20$ with your order, and you will be billed for any labels over 200 .

The above rates for search services were set for 1991. Adjustments reflecting cost increases may have to be made over time.

To request a search report and/or mailing labeis, complete this form and mail it with a check or institutional purchuse order payable to Syracuse University to:

The Center for Research and Information on School-College Partnerships

Syracuse University

111 Waverly Avenue, Suite 200

Syracuse, NY 13244-2320

Telephone: (315) 443-2404; Fax: (315) 443-1524

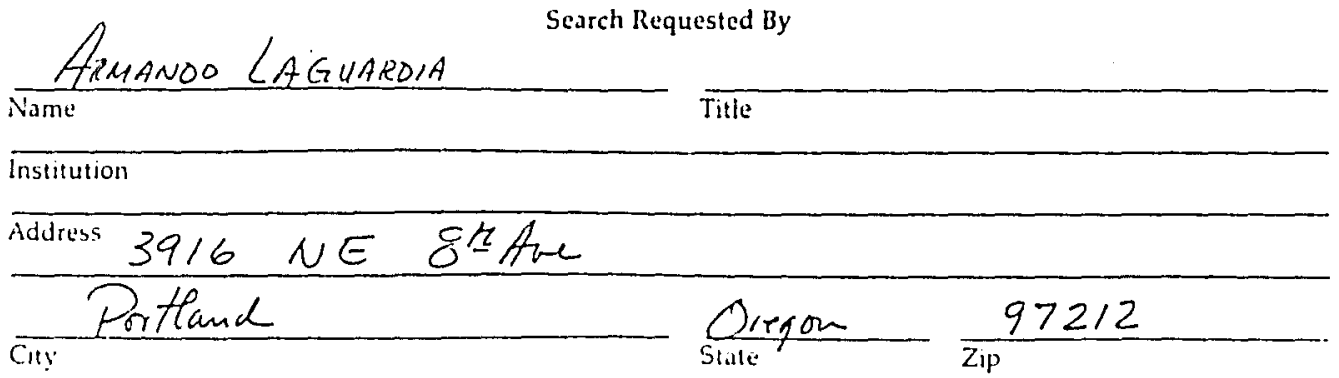

Note: Search reports will be shipped to the above individual and address unless otherwise instructed. 


\section{Search Parameters}

Major Part of Database

Select the major parts of the database you wish to search below. To narrow your search, check as many sections under those parts as you wish.

\section{口 PART ONE: PROGRAMS AND SERVICES FOR STUDENTS}

Xection 1. Serving Underrepresented and At-Risk Populations

$\square$ Section 2. College Courses for High School Students

$\square$ Section 3. Enrichment and Gifted-and-Talented Programs

$\square$ Section 4. Middle Colleges and Early Colleges

$\square$ PART TWO: PROGRAMS AND SERVICES FOR EDUCATORS

$\square$ Section I. Inservice Training and Staff Development

LSection 2. Recruitment and Retention, Preservice Programs, and Early Career Support

$\square$ Section 3. Teacher-Education Centers, Alternative Certification Programs, Teaching Excellence Awards, and School/College Faculty Exchanges

$\square$ Section 4. National Models of Faculty Development and Professional Revitalization

$\square$ Section 5. Programs for Leadership Development and School Management for Teachers, Administrators, and Counselors

口 PART THREE: COORDINATION, DEVELOPMENT, AND ASSESSMENT OF CURRICULUM AND INSTRUCTION

D Scction 1. Curriculum and Instructional Materials Development

$\square$ Section 2. Instructional Research, Evaluation, and Testing

$\square$ Section 3. Tech-Prep 2+2 and Coordinated Vocational-Technical Programs

Xection 4. Regional and Statewide Inter-Institutional Articulation Councils and Agreements

D PART FOUR: PROGRAMS TO MOBILIZE, DIRECT, AND PROMOTE SHARING OF EDUCATIONAL RESOURCES

A Section 1. Coordinating Councils and Consortia for School Improvement

Section 2. Adopt-A.School

$\square$ Section 3. Tutoring and Volunteer Programs

$\square$ Section 4. Magnet Schools

Section 5. Resource-Shuring Agreements

Grade Level

If you wish to restrict your search by grade level, please indicate this below. Otherwise, your search will include all available programs for all grade levels.
口 Elementary school
$\square$ Middle school
Q High school

Geographic Area

If you wish to restrict your search to partnerships from a particular geographic area, indicate this below. You may specify one ur more states $O R$, in the case of cities or regions, one or more postal zip code areas. Otherwise, your search will include all available programs nationwide.

- D State(s) to be included:

C Zip code(s) to be included: 
Focus Codes

One final way you can tailor your search is by the use of focus codes. Check as many of the following codes as are appropriate to your needs.

$\square$ Basic Skills/Study Skills
$\square$ Bilingual/ESL
$\square$ Business
$\square$ Critical Thinking/Problem Solving
$\square$ Cultural/Pluralisn
$\square$ Drug/Sex Education, Suicide Prevention, Child Abuse
$\square$ Early Childhoud
$\square$ Ecology/Environmental lssues
$\square$ Engineering/Technology/Computers
$\square$ English/Writing/Language Arts/Reading
$\square$ Foreign Languages
$\square$ Clobal Education/lnternational Studies
$\square$ Health Professions/Health Education

$\square$ Leadership/Development
$\square$ Library
$\square$ Literacy
$\square$ Mathematics
$\square$ Music/Art/Performing Arts
$\square$ Parental Involvement
$\square$ Research
$\square$ Science
$\square$ Sucial Science/Social Studies/Government/
Civics/Law/Economics
$\square$ Special Education
$\square$ Sports/Recreation/Physical Education
$\square$ Vocational/Occupational Education

\section{Mailing Labels}

If you would like mailing labels produced in conjunction will a database search and report, please check one of the following two formats for pressure-sensitive, pin-feed labels:

$\square$ One-across labels (single strip)

$$
\text { Four-across labels }
$$

\section{Payment/Delivery}

Every attempt is made to process and ship all requests for reports and/or labels within 10 working days of recejpt. Plense attach a check or institutional purchase order to each request. If you have any questions regarding your order, call the Center at (315) 443-2404 from 9:00 AM to 4:00 PM EST, Monday through Friday. Fax requests or inquiries can be received anytime at (315) 443.1524 . 
APPENDIX C

SURVEY QUESTIONNAIRE 


\section{SURVEY QUESTIONNAIRE}

Please check the appropriate box to answer the following questions:

1. Is there a written agreement which establishes the partnership?

Yes $\square$ No

2. Is there a specific person who has responsibility for coordinating the partncrship?

Yes $\square$ No

If yes does this person have the responsibility as a full time assignment?

$$
\text { Yes } \square \text { No }
$$

3. Is there a formal coordinating committe guiding the direction of the partnership?

Yes $\square$ No

4. Does your partnership have formally defined goals?

Yes $\square$ No

5. Is the achievement of the goals of your partnership monitored?

Yes $\square$ No

6. Do you consider your partnership to be successful in achieving its goals and objectives.

Yes $\square$ No $\square$ Somewhat successlu!

7. Which of the following do you consider to have influenced the initial formation of your partnership most. (Please check one of the boxes)

\begin{tabular}{|c|l|c|}
\hline $\begin{array}{c}\text { The leadership of } \\
\text { one individual }\end{array}$ & $\begin{array}{l}\text { Collaboration } \\
\text { between the } \\
\text { institutions }\end{array}$ & $\begin{array}{c}\text { Community and } \\
\text { business } \\
\text { demands. }\end{array}$ \\
\hline & & \\
\hline
\end{tabular}


8. To what extent has each of the following partnership objectives been met? (Please rate each of the following on a scale of 1-3 with 1 being not at all and 3 being to a substantial degree. Use 0 to indicate that the item is not an objective)

\begin{tabular}{|c|c|c|c|}
\hline Not At All & Some & $\begin{array}{c}\text { To a } \\
\text { Substantial } \\
\text { Degree }\end{array}$ & $\begin{array}{c}\text { Not An } \\
\text { Objective }\end{array}$ \\
\hline 1 & 2 & 3 & 0 \\
\hline
\end{tabular}

a. Improve the preparation of minority and disadvantaged high school students.

b. Increase minority/ disadvantage student enrollment in higher education

c. Improve college student retention rates

d. Stimulate Research

e. Promote professional relationships between college and public school staffs

l. Improve the image and community relations of the college

g. Institutional change or reform

h. A base for seeking external funds has been developed

i. Other

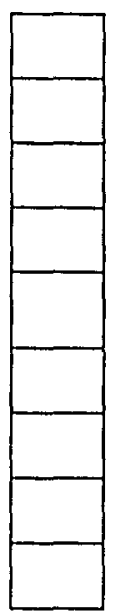

9. What data are collected to measure the success of the students involved in your partnershin?

(Check all that are appropriate and indicate the source of information. )

Source of Data

a. High school graduation rales

b. College preparatory course enrollments.

c. SAT scoles

d. Grade Point Averages (GPA)

c. College enrollment ratcs.

f. College graduation rates

2. Level of funding of the partuership

1. Level of linancial support for the college cinrulleces

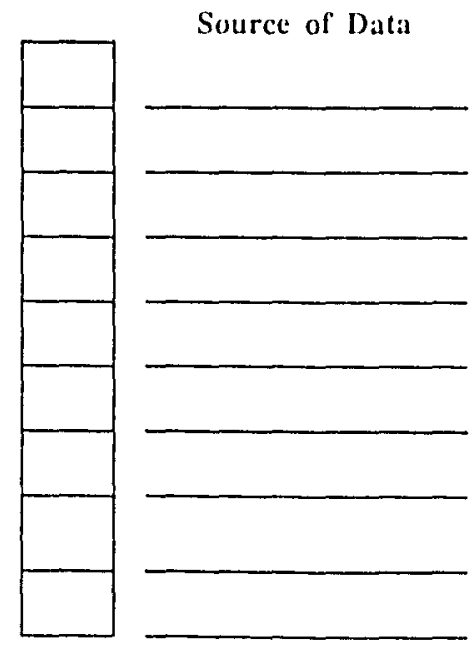

i. ()her 
10. How reliable do you consider the following as indicators of success for your partnership. Please check the appropriate box.

Very Noderately Not at all Not an indicator

a. High school graduation rates

b. College preparatory course enrollments.

c. SAT scores.

d. Grade Point Averages (GPA)

c. College enrollment rates.

f. College graduation rates

g. Level of funding of the partnership

h. Level of financial suppon for the college cenrollees

i. Other

\begin{tabular}{|l|l|l|l|}
\hline & & & \\
\hline & & & \\
\hline & & & \\
\hline & & & \\
\hline & & & \\
\hline & & & \\
\hline & & & \\
\hline & & & \\
\hline & & & \\
\hline
\end{tabular}

11. Please indicate the approximats percentage of the operating hudget of the partnership (combine hard dollars and in-kind contributions) provided by each of the partners .

Percentage

Of Total Budget

a. 4 year college or universitics

b. School Districts

c. Community colleges

d. State

c. Foderal

i. Privale Foundation

g. Business/lndustry

h. ()her Sources 
12. What is the total annual operating budget of your partnership?

Less than $\$ 50,000$

$\$ 50,000)-\$ 99,999$

$\$ 100,(10) 0--\$ 2999,999$

More than $\$ 3(0),(100)$

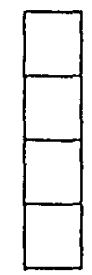

Please return this questionnaire in the enclosed envelope addressed to:

Armando Laguardia

3916 NE 8th Ave

Portland Oregon 97212

Thank you very much. 
APPENDIX D

CORRESPONDENCE 
Mr. Ted Dooley

Director, Boston Compact

Boston Public Schools

26 Court St.

Boston, Mass. 02108

Dear Mr. Dooley

I am conducting a national study of partnerships and collaborations created to prepare and motivate minority and disadvantaged students to succeed in secondary school and enroll in postsecondary institutions.

I have identified a small number of partnerships in the nation that enjoy the cooperation and support of several educational institutions and their surrounding communities, The Boston Higher Education Partnership is one of them. At this time I am asking a small number of persons who have been active in the operation of these partnerships to assist in this national study by completing the attached questionnaire. Your name was given to me by Robert Sperber. The questions are designed to inquire about some of the characteristics of your partnership, and how you measure your success.

I have been part of the current partnership movement for several years and have taken this opportunity to seek much needed information that can be of service to the education community. The information you contribute will be used to increase our understanding of the elements that make partnerships successful.

In addition to contributing to my doctoral studies at Portland State University the information I gather will be shared with the National Center for the Study of Partnerships at Syracuse University and will become part of a knowledge base that can benefit us all.

Please take a few minutes to answer the questions to the best of your ability and return the questionnaires to me by April 8th 1994 in the enclosed addressed and stamped envelope.

Thanks for your cooperation. Your contribution is deeply appreciated Sincerely 
APPENDIX E

INTERVIEW PROTOCOL 


\section{INTERVIEW PROTOCOL}

\section{Preface to the interview.}

The following statement was made prior to the interview.

I am conducting interviews as part of a national study on the factors that have made some partnerships successful in improving the opportunities for ethnic minority students to succeed academically in school and to enroll in postsecondary institutions. Initial inquires through surveys have identified your partnership as one of the most successful in the nation in the accomplishment of its goals. One of my interests is to get a better understanding of the factors and actions that have lead to your collective success. I want to accomplish this by talking with several key players in a select number of partnerships and inquire in more detail about the factors that have contributed to success and provided challenges. I am hoping that you can provide me with your own perspective on these factors based on your personal experiences and opinions.

\section{INTERVIEW PROTOCOL QUESTIONS}

1. Describe the leadership roles in the formation of the partnership. Who was involved? What role did the different people play?

2. Describe the leadership roles in the continuing operation of the partnership.

What role do the different people play? Is commitment to the partnership evident? In what ways?

3. The survey you completed indicates that the partnership goals are relatively clear. In what ways does the partnership make the goals clear? Does the partnership use different strategies to clarify its goals to the different communities? 
4. How would you describe the manner in which the partnership makes major decisions? Can you provide an example?

5. Is there other evidence of the success of the partnership that is not reflected in existing data?

6. Does the management of the partnerships include a mechanisms for sharing information between the participating institutions? How is this done? Can you provide examples?

7. What does the partnership see as the "time frame" for its work? How does this time perspective play out in its activities?

8. Has the partnership affected any significant institutional change? How do you define these? How do you know that these changes have made a difference?

9. Is there evidence of increase in trust or improved relationship between college and school staffs?

In what areas were the improvements?

10. How does the staff at the participating institutions demonstrate support for the partnership?

What impact does their support have?

11. Tell me how the parnership is funded. How are decisions made about the nature and source of funds? Who makes these decisions? How does the level, source and continuity of funding affect the partnership goals?

12. Tell me about the "balance" between the members of the partnership. Who does what? What process is used to ensure that each member contributes relatively equally to the goals of the project?

13. Have there been specific actions you have undertaken that have been helpful in:

(a) Academic preparation of high school students?

(b) Enrollment of minority students in postsecondary education? 
14. Tell me the partnerships position on the retention of minority students in postsecondary institutions. Is it an issue? Whose issue ? How is it being addressed?

15. What evidence exists that the image of the participating postsecondary institutions has been improved by the formation of the partnership?

16. Is partnership formation and the development of collaboratives recognized and or studied by the partnership?

How is it done? What have you learned? 